\title{
Indigenous Fish Traps and Weirs of Queensland
}

\author{
Michael J. Rowland ${ }^{1,2}$ and Sean Ulm²
}

1 Cultural Heritage Coordination Unit, Department of Environment and Resource Management, GPO Box 2454, Brisbane, QLD 4001, Australia mike.rowland@derm.qld.gov.au

2 Department of Anthropology, Archaeology and Sociology, School of Arts and Social Sciences, James Cook University, PO Box 6811, Cairns, QLD 4870, Australia sean.ulm@jcu.edu.au

\begin{abstract}
A Queensland state-wide review of coastal and inland fish traps and weirs is undertaken. More than 179 sites are described. For coastal Queensland, it is demonstrated that traps with multiple pens are common in the Torres Strait and at a limited number of locations in the southern Gulf of Carpentaria. Most traps and weirs south of Torres Strait and the Gulf are isolated structures, with traps in most cases having a single pen. Walls of traps are most often in the shape of an arc and found at points and estuaries and only occasionally on open beaches. Some traps and weirs on the coast were built or used by non-Indigenous people, including South Sea Islanders. Less information could be located on traps and weirs of inland Queensland, which appear to have included many organic traps and weirs. It was found that weirs are common east of the Great Dividing Range, while traps were common to the west. The review draws heavily on unpublished data and reports held by the Queensland Department of Environment and Resource Management. The use of this information along with published sources, theses, explorer's diaries and ethnographic accounts allows a comprehensive overview of available information. Fish traps in particular are often found in coastal zones subject to development pressure and this work provides a baseline resource to generate discussion about research and management of this significant site type in these zones.
\end{abstract}

\section{Introduction}

Indigenous people throughout Australia have constructed fish traps and weirs over a long period of time and there is considerable variety in types, numbers, size and location of these sites. They were designed to capture aquatic animals, predominantly fish, and the more durable of these structures (i.e. those made of stone) are still visible on Australia's coasts and rivers today. Fish were also caught in natural pools and in a variety of small portable traps but this review focuses predominantly on the more substantive and durable non-portable devices.

Fish traps have assumed an important place in discussions concerning late Holocene Aboriginal culture change, in particular their possible role in increasing marine production (Lourandos 1997). However, attempts to directly date these structures have so far been unsuccessful (e.g. McNiven 1994) with chronology often established through dating of associated cultural deposits (e.g. Bowen 1998; Ulm 2006). Recent discussions (e.g. McNiven 2003) have also developed the idea that some stone features in the intertidal zone are associated with the cosmological landscape rather than serving a purely economic function. As McNiven (2003) demonstrates with examples from the Torres Strait, the two spheres are not mutually exclusive with large fish trap complexes playing a key role in the way that landscapes and seascapes are inscribed with social meaning. Welz (2002) has also attempted to interpret the fish traps of the Lower Eyre Peninsula in the context of cultural and environmental variables using a landscape approach.

In an unpublished report on Queensland traps and weirs produced by Bowen and Rowland (1999) an attempt was made to identify the range of site types, methods of construction, distribution across the landscape, antiquity, possible origins, and possible overall economic function. The report sought to identify criteria that could be used to discriminate between Indigenous traps and those made by Europeans and South Sea Islanders who have built similar traps, weirs and other stone structures. Recommendations were made concerning the future recording and management of traps and weirs in Queensland (see Bowen and Rowland 1999). A potential method for dating traps and weirs was also developed as part of that study and is discussed elsewhere (Bowen 1998).

This paper builds on the results of Bowen and Rowland's (1999) study to provide a comprehensive review of information pertaining to Indigenous fish traps and weirs in Queensland. The review provides a baseline resource to generate discussion about research, management and other issues. The Queensland Department of Environment and Resource Management Indigenous Cultural Heritage Database (ICHD) provides the basis for this review, supplemented by published articles and books, as well as unpublished reports and theses. An attempt has been made to incorporate information from a wide range of sources, including explorer's diaries, ethnographic accounts, and cultural heritage surveys. Many of the sources reviewed here are not published or have limited availability, enhancing the value of assembling this reference work. Published summaries of site types for Australia, individual States or Territories, or regions are rare (e.g. Hiscock and Mitchell 1993) and it is hoped this review might encourage others to undertake similar reviews since they are extremely valuable for comparative purposes and for providing a strategic focus for future research and management.

The review is organised into three major sections. The first two sections synthesise descriptive information about the types and distribution of traps and weirs in coastal and inland areas respectively. For simplicity, an arbitrary geographic division of Queensland into five zones is employed: Gulf of Carpentaria, Torres Strait, Northeast, Central and South (Figure 1). The final section considers key research and management themes arising from the review, including determining the origins of traps and weirs, patterns in distribution, function, dating, and best 
MAP 1
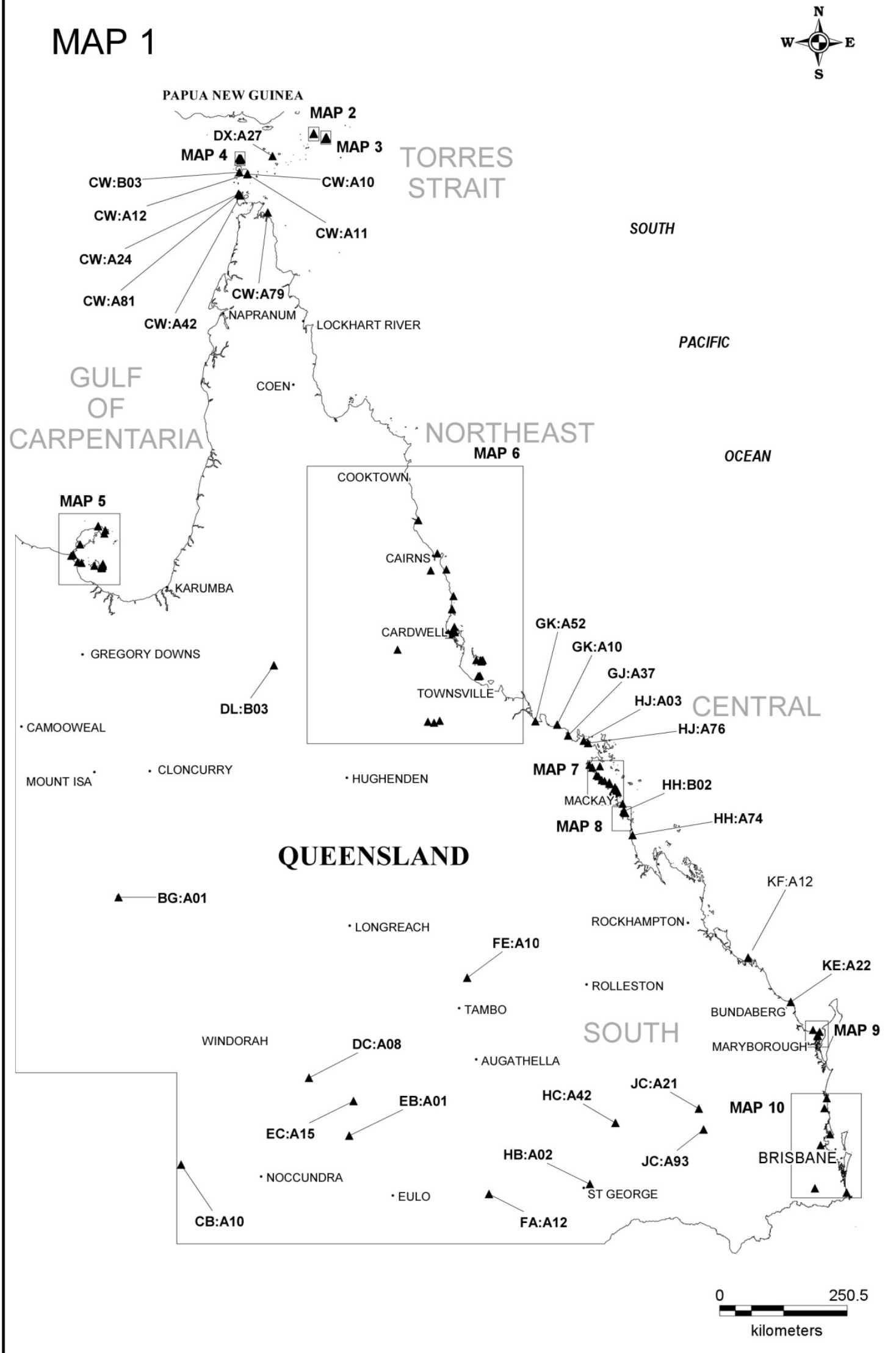

Figure 1. Fish traps registered on the ICHD and major geographical divisions employed in this discussion: Gulf of Carpentaria, Torres Strait, Northeast, Central, South. 
practice guidelines for documentation and monitoring. A comprehensive listing of traps and weirs registered on the ICHD is provided in Appendix A, which includes information about basic site attributes. Note that not all sites listed in Appendix A are discussed in the text owing to limited information (CW:B03, FK:C80, JC:A21, KA:A67, KA:A72, KB:F91, LA:C80, KC:D93) or restricted status (DL:B03).

\section{Definitions}

The terms 'traps' and 'weirs' are often used interchangeably (e.g. Clarke 2002:154-157; Connaway 2007:5; Bannerman and Jones 1999). In the Australian ethnographic and archaeological literature however there is a tendency to make a distinction between the two though it is not consistently applied. On a worldwide basis, Connaway (2007:5) defines a 'weir' as an obstruction placed in a stream or tideway or along a shoreline to channel fish into a procurement area, while a 'trap' is a device placed in the procurement area to capture and impound fish for collection but again the terminology is often used interchangeably. In this discussion we have tended to use the term used by the recorder or observer. Fish traps and weirs in Australia range from slight modifications to natural features of the landscape to special purpose-built structures (Mulvaney and Kamminga 1999:34-35). A 'trap' is generally defined as an artificial structure (normally made of stone) found predominately in the intertidal zone with a length and breath that creates a holding area (cf. McNiven 2003). A trap may contain a single or multiple pens.

A trap with a clearly identifiable pen may be relatively easy to identify, however, a trap whose areas are further subdivided into pens may be decidedly more difficult to define. Memmott et al. (2008) faced with these methodological problems decided on an interim working decision to treat each single wall feature as a unit and defer abstract interpretation (i.e. definition of a pen) until further fieldwork.

On the coast traps are found in the intertidal zone where advantage is taken of fluctuating water levels. The walls of the trap must be low enough for fish to swim in at high tide, but high enough that some are captured at low tide. A weir is generally considered to be a smaller structure than a trap - a fence or wall that spans natural conduits of water, such as creeks, streams, coves or similar formations. Although also made of stone, weirs are frequently made of organic materials such as wood. In his worldwide review Connaway (2007:14) notes that for tidal fishweirs wooden stakes and brush or nets are preferable to rocks, considering the often larger size of the weirs and the distance that many rocks would have to be hauled. Connaway's review makes only cursory reference to the Australian literature which indicates that rocks were more commonly used than stakes.

Traps and weirs were constructed almost exclusively of locally available stone or organic materials and sometimes gaps were left in the walls where nets or cages were positioned to capture prey as they swam through. While traps and weirs require some effort to build and maintain, as stationary structures that simply rely on prey moving into them, they require little effort in actual food gathering (e.g. King 1995:65). Ethnographic literature relating to the Coorong estuary and Lower Murray Lakes of South Australia indicate that the most common type of fish trap was a V-shaped weir. They may have been built on bases of eroded calcreted Pleistocene dunes using a combination of loose limestone blocks and wooden sticks but detailed surveys of the areas failed to find any archaeological traces of these sites (Ross 2009). Fish traps may therefore have been more common on Australia's coastline than the physical remains suggest.

We identify five primary pen shapes or forms (see also McNiven 1994:92) (Table 1, Figure 2). The most common form is the U- or arc-shape followed by the Vshape. With a small surface area exposed to water, these shapes are better able to disperse pressure, and thus remain intact compared with those with a larger surface area, such as a square. They degrade slowly and thus require minimal maintenance (Meriam and Kraige 1987:270-280). Some traps have a single pen, while others have multiple pens, which may in some cases have been designed for the purpose of dividing and holding fish (Van Waarden and Wilson 1994:81).

Most of the traps and weirs reviewed here are registered on the ICHD and are referred to using their site number based on the 1:250,000 map sheet series for Queensland (i.e. the site designated FL:C09 refers to the Ingham sheet and is the $209^{\text {th }}$ site recorded for the map sheet. Sites are numbered A1-99, B100-199, C200-299 etc). Other fish traps are not registered on the ICHD, but are described in published and unpublished sources.

\section{Table 1. Primary fish trap or pen forms (see Figure 2 for examples).}

\begin{tabular}{|l|l|}
\hline \multicolumn{1}{|c|}{ Type } & \multicolumn{1}{c|}{ Description } \\
\hline U-shaped & $\begin{array}{l}\text { An arc-shaped curve oriented so that the } \\
\text { open end faces the shore. Also referred to } \\
\text { as 'arc'. }\end{array}$ \\
\hline V-shaped & $\begin{array}{l}\text { A 'V'-shaped variant of the arc-shaped } \\
\text { trap, again with the open end facing the } \\
\text { shore. Also referred to as 'funnel'. }\end{array}$ \\
\hline O-shaped & $\begin{array}{l}\text { A continuous curve. Also referred to as } \\
\text { 'circular' or 'oval'. }\end{array}$ \\
\hline Straight & Also referred to as 'square'. \\
\hline Rectangular & \\
\hline
\end{tabular}

\section{Types and Distribution of Traps and Weirs: Coastal}

\section{Torres Strait}

Throughout the Torres Strait Islands fishing was important with fish traps a common component of the wide-range of fishing techniques employed (Barham 2000:258-265) (see Figures 3-5). When Haddon (1935:158-159) visited the area he noted that traps lined the shores of 'practically every island', most commonly in the eastern islands (where they were called sai), though they also occurred on some of the western islands (where they were called graz). Haddon (1935:158-159) indicates that fish traps were typically built on the eastern side of islands and were used during the northeast monsoon when waters on the lee-side of an island were calm, but were damaged during the southeast monsoon season when they were not used. However on Erub, smaller fish trap complexes also occur on the southwest and north-facing 

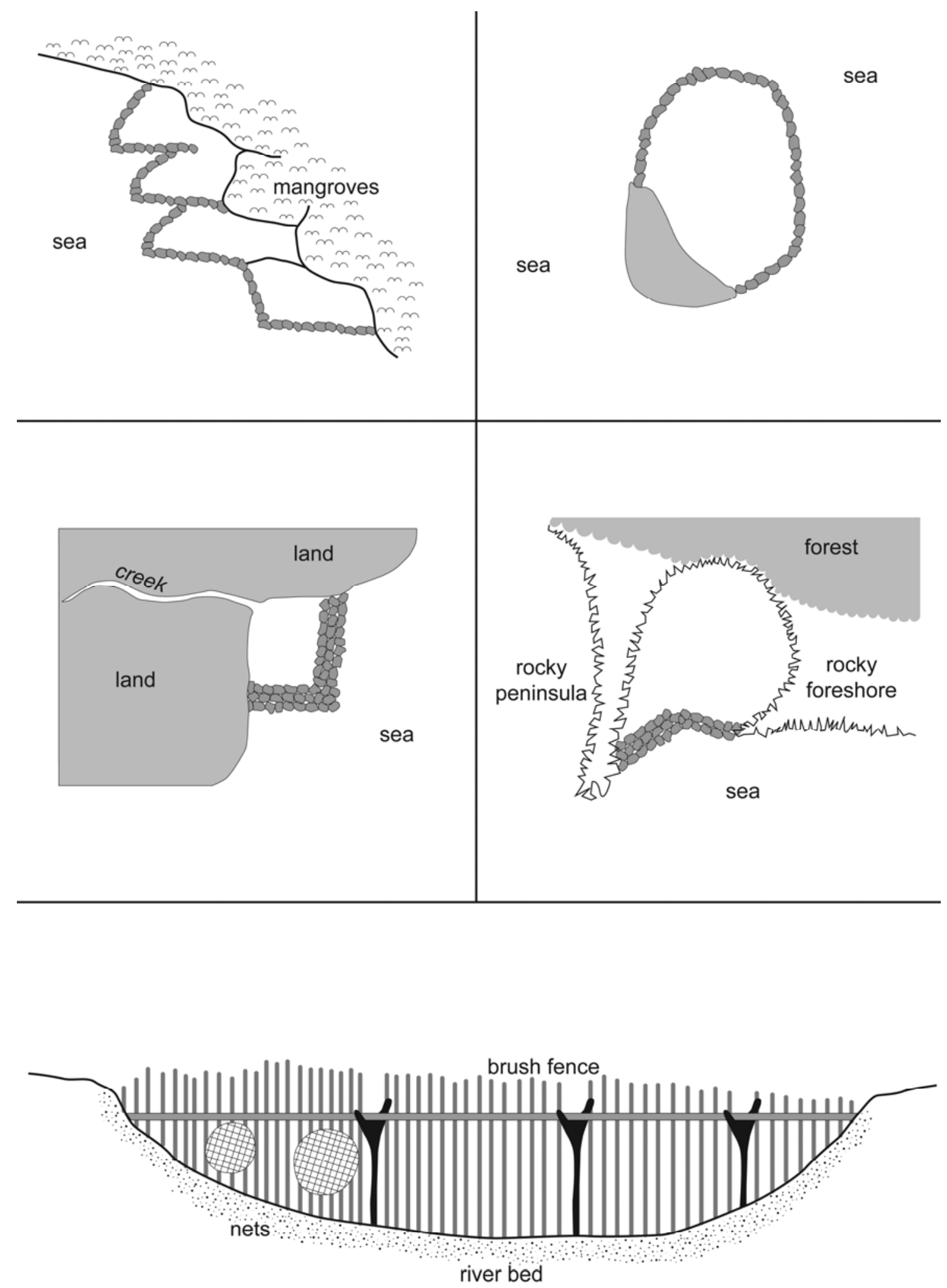

Figure 2. Primary fish trap or pen forms (Bowen and Rowland 1999:Figure 1.1a). Clockwise from top left: Vshaped, U-shaped, straight and rectangular. Bottom: organic weir across river. 
MAP 2
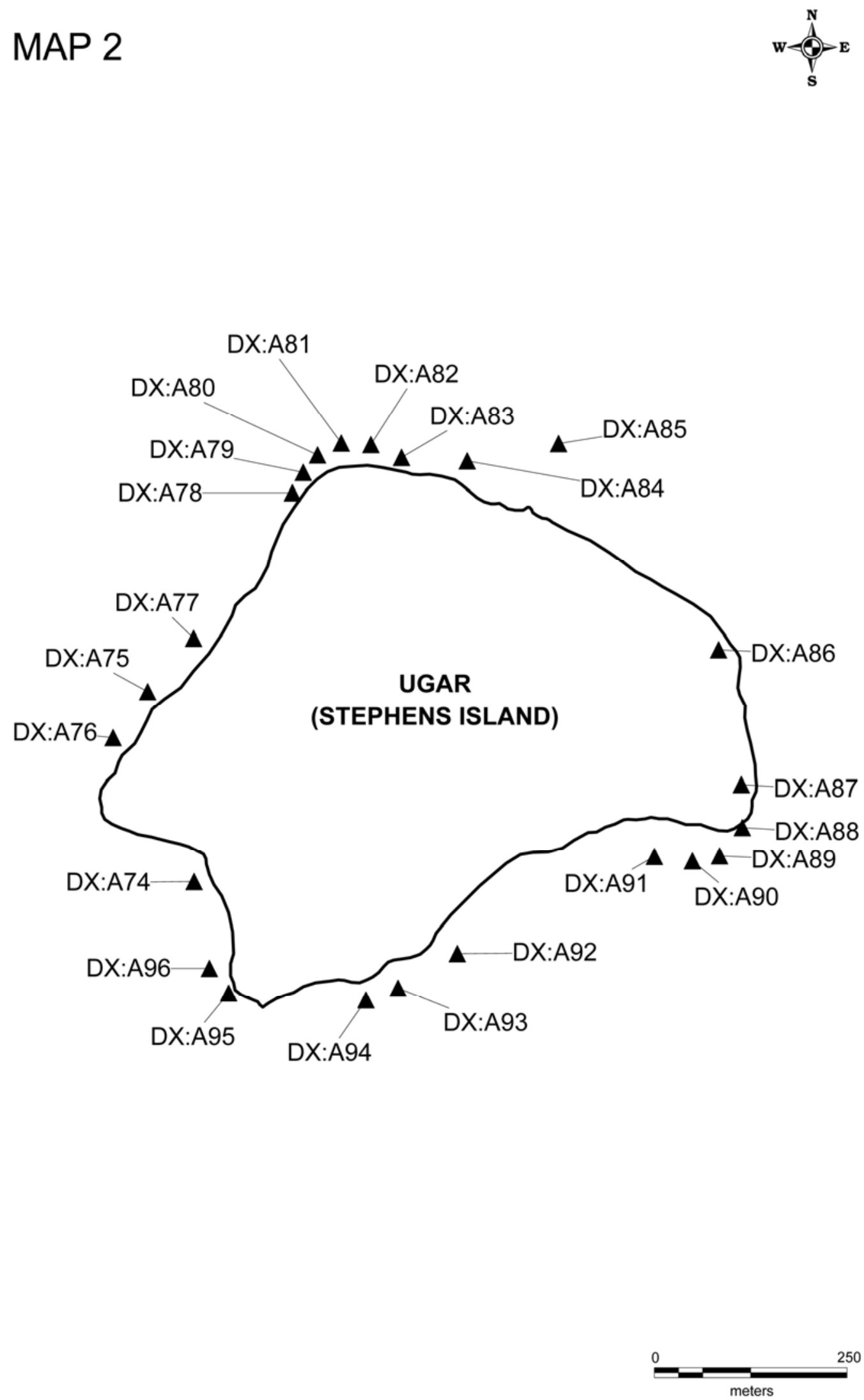

Figure 3. Fish traps registered on the ICHD, Ugar (Stephens Island), Torres Strait. 


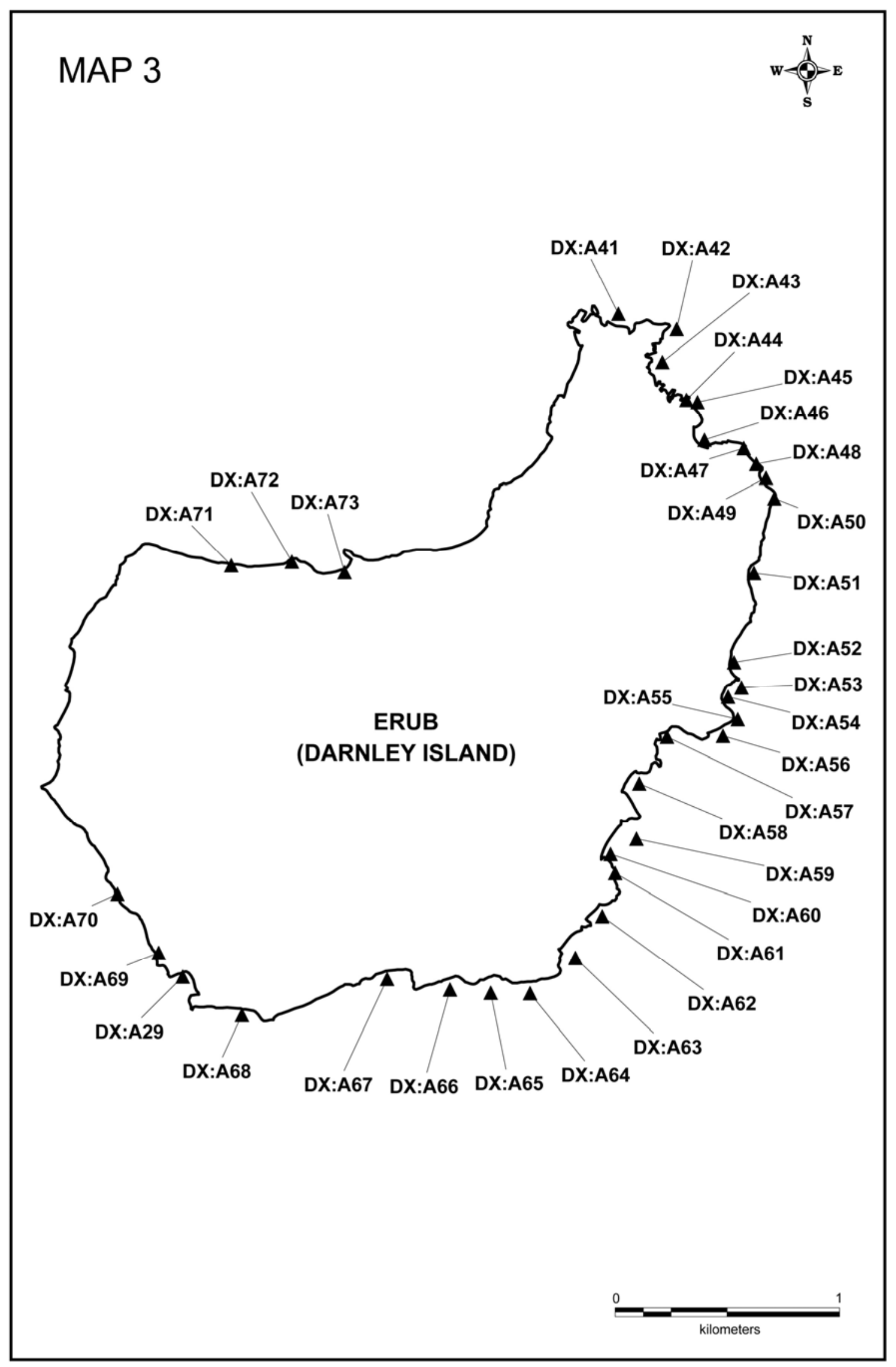

Figure 4. Fish traps registered on the ICHD, Erub (Darnley Island), Torres Strait. 
MAP 4
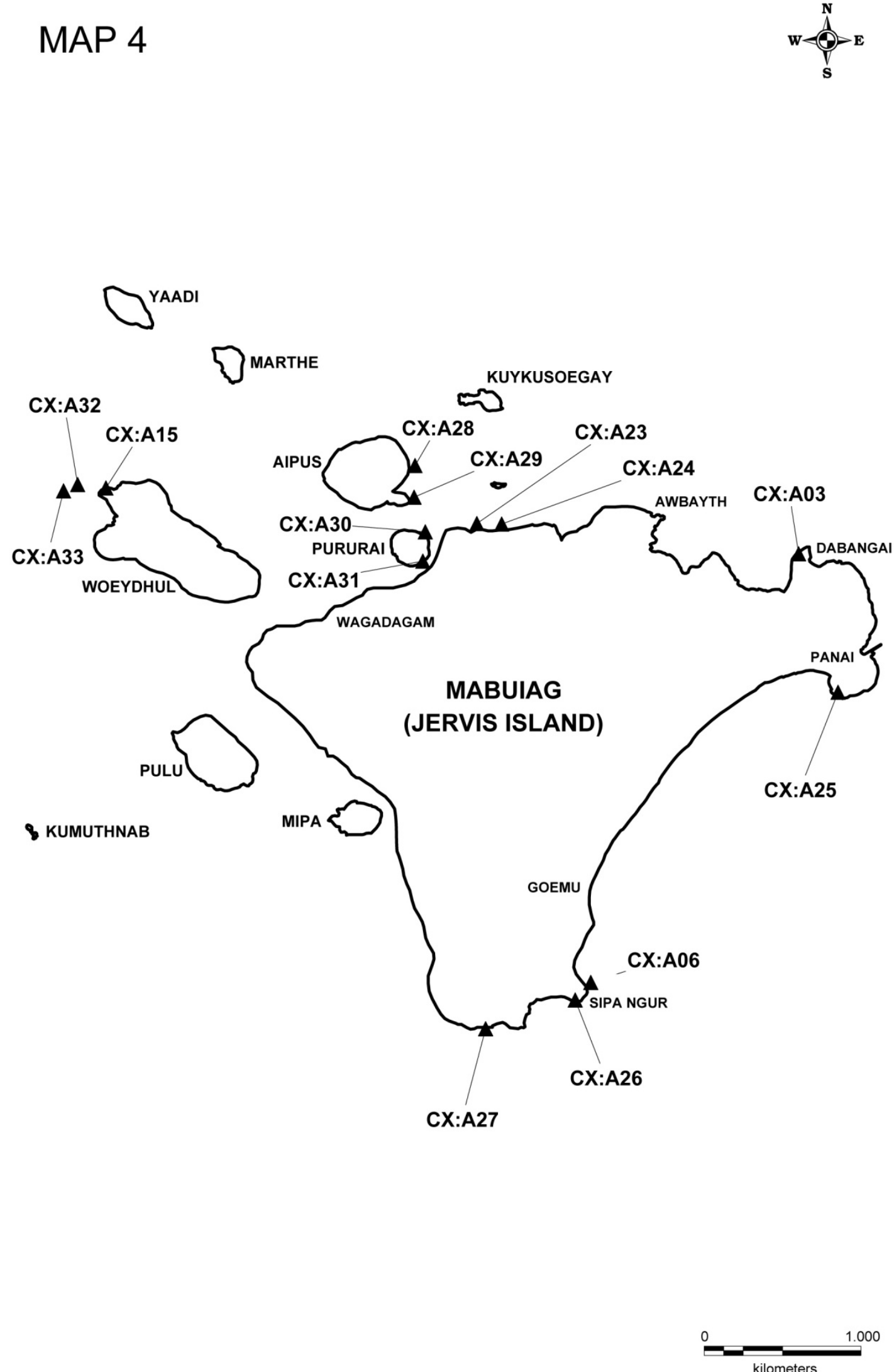

Figure 5. Fish traps registered on the ICHD, Mabuiag (Jervis Island), Torres Strait. 
coast (Barham 2000:263). Haddon's view therefore may be misleading and consequently the view that the use of fish traps was seasonally restricted to the wet season (see Ghaleb 1990; Haddon 1912:179) has also been questioned (Barham 2000:261). Haddon (1912:158-159) claimed that people had no memory of making fish traps and that if the ancestral beings Abob and Kos (the reputed inventors and builders) had not been imbued with power exceeding that of mere mortals, the fish traps would never have been built.

Barham (2000:263-264) makes two significant observations concerning fishing and fish traps in the Torres Strait Islands. Firstly, he notes that construction and repair of stone fish traps were described in verse sung during the saw-fish dance songs recorded by Haddon and that similar songs and dances occurred at Batavia River on the mainland, thus pointing to a 'commonality of structure and inherited traditional knowledge within the area of the Torres Strait Cultural Complex' (Barham 2000:264). Secondly, he concludes that the clear implication of early narratives is that fish gathering was comparable in importance to horticulture, at least in the overall diet of the eastern Torres Strait Islanders. Fishing therefore involved concepts of land allocation, demarcation and ownership.

Traps have been reported on Muralag and Moa (Barham 1981), Mabuiag (Harris et al. 1985) and Giralag in the western islands, and Erub, Mer and Ugar in the eastern islands (Barham 2000:260; Bird et al. 1995; Johannes and MacFarlane 1991; Marks 1953). Barham (1981:14-15) observed traps on Muralag and shipwreck survivor Barbara Thompson (in Moore 1979:150-151) who lived on the island in the 1840s also witnessed people catching fish 'by stopping the mouths of a creek when the tide has gone into it with the mats called wakoo and branches'.

Barham (1981) located three arc-shaped stone wall traps on Moa, which were in varying states of preservation. The first trap south of Saveka Point and closest to the beach extended $10 \mathrm{~m}$ north-south and was partially covered by sand and mud (CW:A10). Further seaward was an arc-shaped trap bordered at both ends by the headland with a wall 53m long and gaps of 1-2m between individual stones (CW:A11). Furthest seaward was another arc-shaped trap $74 \mathrm{~m}$ in length with mangroves (Rhizophora sp.) growing over the southern end of it (CW:A12). No plans or sketches of these sites were made (but see Barham 1981:Plates 8-10).

Harris et al. (1985:47) have located and described fish traps on Mabuiag. These include two multiple pen traps, one in the northeast of the island (CX:A03) (Kodakal, immediately west of Dabangai headland) and another in the southeast (CX:A06) (Sipa Ngur headland), as well as 5 (CX:A23-A27) presumably, single-pen traps (Ghaleb 1990). These latter traps were located on the north, east and south coasts on rocky foreshores near mangrove stands. The trap at Kodakal (which was listed as both CX:A03 and CX:A13 and is now listed as CX:A03) was arc-shaped and had two pens with a landward wall 104m long that had been damaged by wave action particularly near its southern extremity. The main trap at Sipa Ngur headland (CX:A06) was arc-shaped with a seaward wall $150 \mathrm{~m}$ in length. A smaller, rectangular trap (no dimensions provided) lay south of the main trap (recorded as part of CX:A06). One of the island elders indicated that fish used to be speared, knifed or caught by hand in the trap, though not in his lifetime. He also indicated that a fish poison known as itamar, which used to be planted on the old mounds at Maid, was used until it was made illegal. The identity of itamar is uncertain, but Haddon refers to it as the leguminous plant Indigofera australis (Australian Indigo) (cited in Ghaleb 1990:165). A helicopter reconnaissance of the coast of Mabuiag undertaken in 1985 revealed four new fish trap locations, including one with a cluster of three separate traps. The absence of traps along the southwest coast was confirmed by the 1985 survey and highlighted the proximity of fish traps adjacent to the village areas of Goemu, DabangaiPanai, Awbayth and Wagadagam (Ghaleb 1990:164-167). None of these traps have been recorded or mapped by ground truthing. Fish traps were frequently located on small rocky islets such as Sarabar and Purarai off Mabuiag where only intermittent occupation would be possible. CX:A15 is recorded on Woeydhul; CX:A28 and CX:A29 on Aipus; CX:A30 and CX:A31 on Pururai; and CX:A32 and CX:A33 on Sarabar (Ghaleb 1990) but no details of the sites have been provided. The distribution of all fish trap locations known on Mabuiag is presented by Ghaleb (1990:Figure 6, Plates 7a-7b). Ghaleb’s (1990) Figure 6 shows the location of seven fish traps on Mabuiag and seven on offshore islets. None of these sites is registered on the ICHD.

A rough sketch of a site on Waibene (Friday Island) in the western islands (CW:A42) is on the site database. It is described as rectangular in shape being approximately $60 \mathrm{~m}$ north-south and approximately $25 \mathrm{~m}$ east-west and appears to have suffered coastal erosion. CW:A24 is a fish trap on Goods Island in the western islands but limited details are provided. It is reported as ' $M$ '-shaped, perhaps referring to multiple $\mathrm{V}$-shaped pens. Another trap on Goods Island was subsequently described in more detail and is listed as Bertie Bay fish trap (CW:A81). It is listed as angular and there is some controversy over its origin though the unknown recorder, believed it dated to pre-contact times. On Brewers Island, a small island due north of Turtle Head Island is a circular trap (CW:A79) approximately $30 \mathrm{~m}$ in diameter and $30-50 \mathrm{~cm}$ high. A recently vacated campsite is located adjacent to the fish trap.

Jukes (1847:181-182) observed traps on the south side of Erub (Darnley) in 1844, noting:

Sandy flats, dry at low water, stretch out two or three hundred yards [180-270m] from the beach, covered with native weirs, for catching fish. These are walls of loose stone, about three feet $[91 \mathrm{~cm}]$ high, formed in curves and semicircles along the sand flats, each having a radius of one or two hundred yards [90-180m]. They are completely covered at high water, but when the tide falls, (its range being about ten feet, [3m]) many fish are left within these enclosed spaces, or, together with crabs and other sea creatures, caught in the interstices of the stones ... Here and there along the shore, both on the beach and out on the sand-flats, were erected tall bamboo poles with long streamers of leaves attached to them, but what was their object we never could discover. I am inclined to believe they are mere boundary marks between the different fishing-grounds of each village or small group of huts (see also Sweatman in Allen and Corris 1977:xxii-xxiii; 25-27). 
Marks (1953:117) observed similar traps made of basalt boulders on Erub and Mer running out from the north and east shores in a series of wide loops. Those on Erub are numerous, are still owned by family groups, and some are still used today (Johannes and MacFarlane 1991:82). A site on Yam Island is listed as DX:A27 and is one recorded by Haddon (1935:373-378) as a low fence of mangrove stakes. Some evidence of the site remained in 1990 when it was recorded by John Singe on the site card. A site on Erub has been mapped in detail (DX:A29) and appears to be site DT28 or DT29 reported by Barham as Badog fishtraps (2000; see Figure 6-7). It is approximately $80 \mathrm{~m}$ from the shore seaward and also $80 \mathrm{~m}$ at its widest point. Barham (2000) indicates the presence of at least 34 fish traps on Erub. These have been designated site numbers DX:A41-DX:A73 but full details have not been provided (see Figures 4 and 6).

Bird et al. (1995:7) describe the traps on Mer as rectangular, instead of circular, and located on the south and east shores. They note that fish were trapped at night during the ebbing tide and were speared or netted, although hand lines or poison (sad) were occasionally used. While many of the traps were the property of the clan that owned the adjacent land, the entire community rebuilt the structures once a year in exchange for fish from the first catch. Johannes and MacFarlane (1991: Figure 5) have comprehensively described these traps. They note that fish traps (sai) with walls built of basalt rocks are spread along the north and east sides of the island, on the inner portion of the reef. Fish and other marine animals are trapped within the walls on receding tides and tend to gather in the deepest parts or 'corners' of the traps, which are generally found along the walls. Different families, who traditionally held the right to the fish trapped in them, sometimes owned different corners. In earlier times internal rock fences apparently marked off these subdivisions. They refer to observations by Davies in the 1920s that these fences were called belcars and that it was 'criminal' to take fish from another family's section. Davies claims he often saw sai on Mer being repaired after storms but Johannes and MacFarlane (1991:76) indicate that today only a few sai are occasionally repaired.

Johannes and MacFarlane (1991:99-100) note that sai are numerous in the eastern islands and have in the past yielded a fairly steady supply of marine resources without entailing much more effort than periodically repairing the walls. They describe sai as consisting of a semicircular wall of lava rocks about $1 \mathrm{~m}$ high and enclosing a portion of the reef flat. The wall usually stops at the beach near the high tide line. Typically, sai have a radius of between $50-150 \mathrm{~m}$. There are 23 such sites visible on the reef flat at Mer, 24 at Erub and 23 much smaller ones on Ugar (Figures 6-10). Barham (2000:Figure 7) notes the existence of 23 fish traps on Ugar (Figure 10) which are now listed as DX:A74-A96 (Figure 3). Johannes and MacFarlane (1991:99:Footnote 1) have highlighted the magnitude of the task of building the traps. They note that the lava rocks must have been brought from the bush since only coral rocks occur on the reef flat. On Mer alone they indicate there is roughly $7 \mathrm{~km}$ of sai walls and estimate that each metre of wall contains about 0.5 tonnes of stone. Thus the sai on Mer would contain about 3,500 tonnes of rock. If the average weight of rock that could be carried from the bush were $35 \mathrm{~kg}$ per person, construction of sai would have required around 100,000 person trips to and from the bush. This represented a significant investment of labour. The distribution of fish traps around Mer is shown in Johannes and MacFarlane (1991:Figure 5) (see Figures 8-9). They are extensive on the western side of the island.

The use of fish traps in the Eastern Islands appears to have varied during the past century. In 1836 it was reported that Erub islanders were working on a trap of very large dimensions but in other reports as far back as 1866 traps were said to be no longer in use (Johannes and MacFarlane 1991:99). A small number of sai in the Eastern Islands are still used sporadically today. The walls of the traps are completely submerged by high spring tides. When the tide falls and the walls are exposed fish are trapped, along with the occasional turtle and, very rarely, a dugong. As the tide drops further, the fish are easily captured by hand or with a spear, especially at night by the light of a torch or pressure lamp. Catches are much better during nocturnal spring low tides of the northwest monsoon season than during the southeast trade season, when spring low tides occur during midday. It is reported that fish are less likely to escape over the sai on falling tides at night than during the day. Catches are said to be especially good on dark rainy nights when the water is dirty. The fish caught in greatest numbers in the sai, according to Islanders, are mullet, trevally and spinefoots (rabbitfish) (Johannes and MacFarlane 1991:100). Most of the sai are on the weather side of the islands and during the southeast trade wind season floating logs, presumably carried into the Strait in the outflow of the Fly River, breach their walls. Repairs are carried out at the beginning of the northwest monsoon season. On Mer in the 1920s Davies observed people carrying boulders out from shore for the purpose of repair. They were carried on a bamboo frame slung between two canoes. Islanders informed Johannes and MacFarlane (1991:99-100) that because only a few traps had been repaired on Mer and Erub in recent years, they were not nearly as important a source of food as they once were. Lawrie (1970:342-343) assisted with the repair of a fish trap on Mer in February 1967 and notes that some fish traps are repaired regularly during the northwest monsoon. Lawrie (1970:343) includes a photograph of 15 men, women and children repairing the fish trap. Traps on Ugar are no longer kept in repair although Islanders still manage to obtain fish from some of them. 


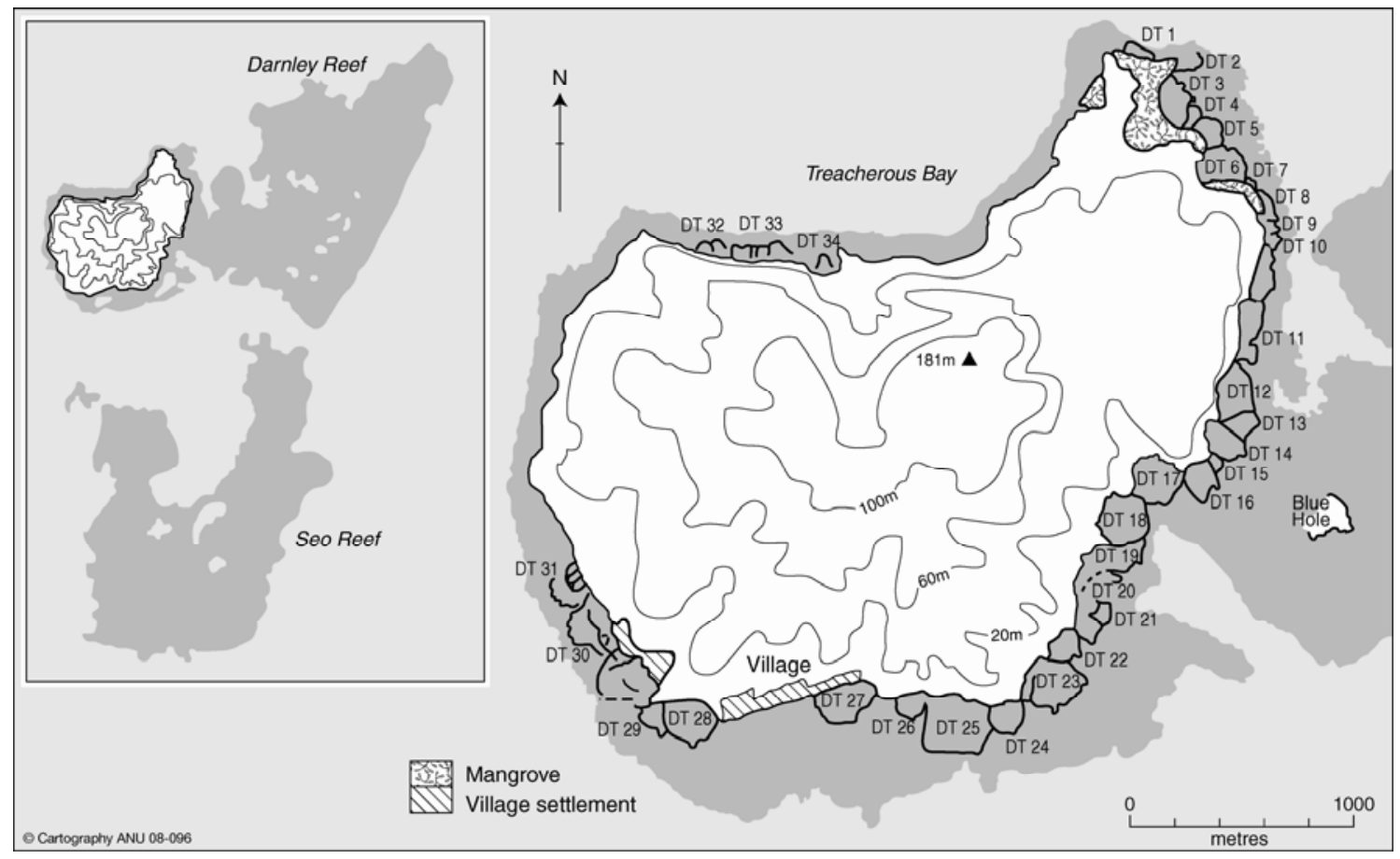

Figure 6. Fish traps recorded on Erub (Darnley Island) (Barham 2000:Figure 6). See also Figure 4.

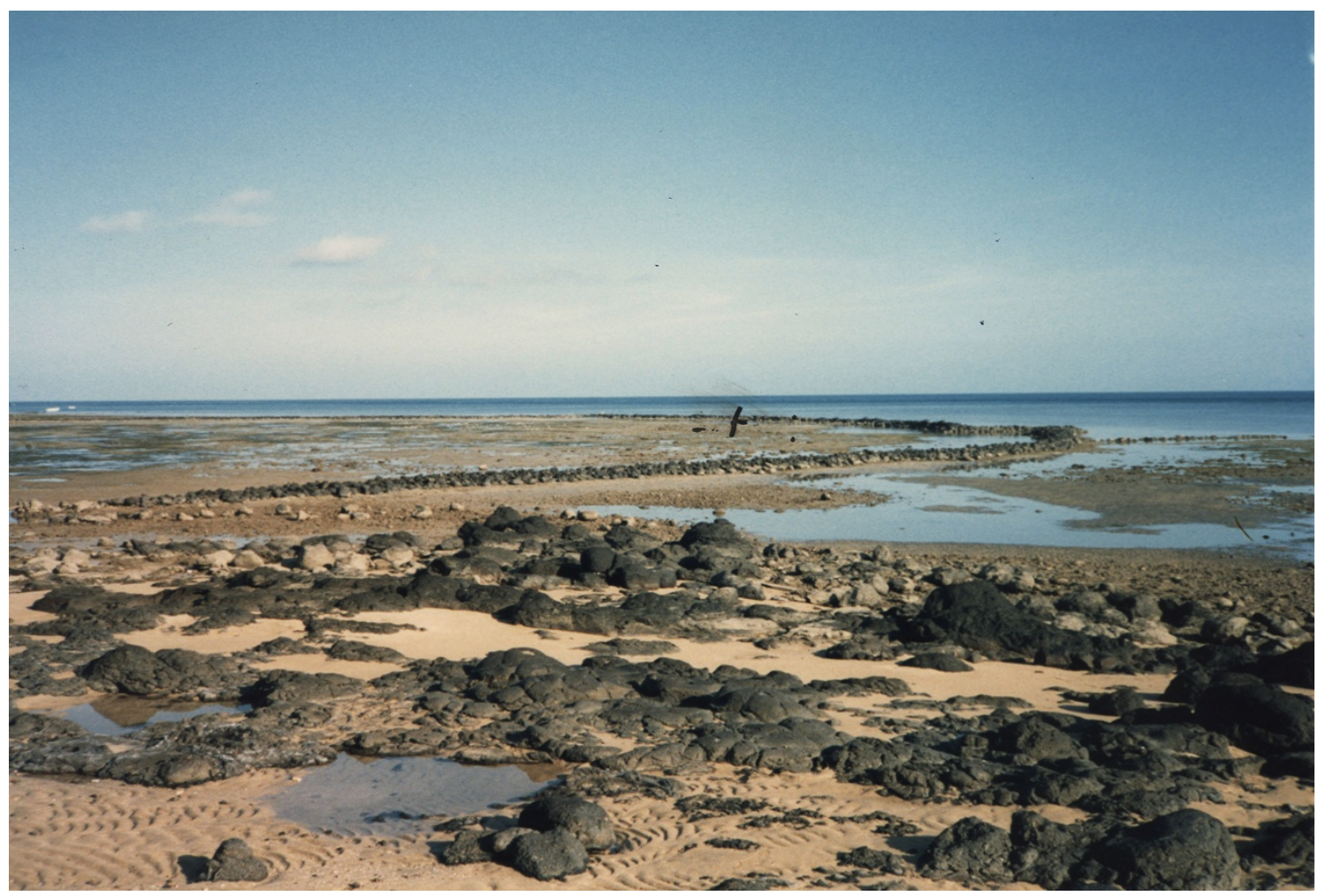

Figure 7. Fish trap DX:A29 at Badog Village, Erub (Darnley Island) (DERM ICHD Slide Collection). 


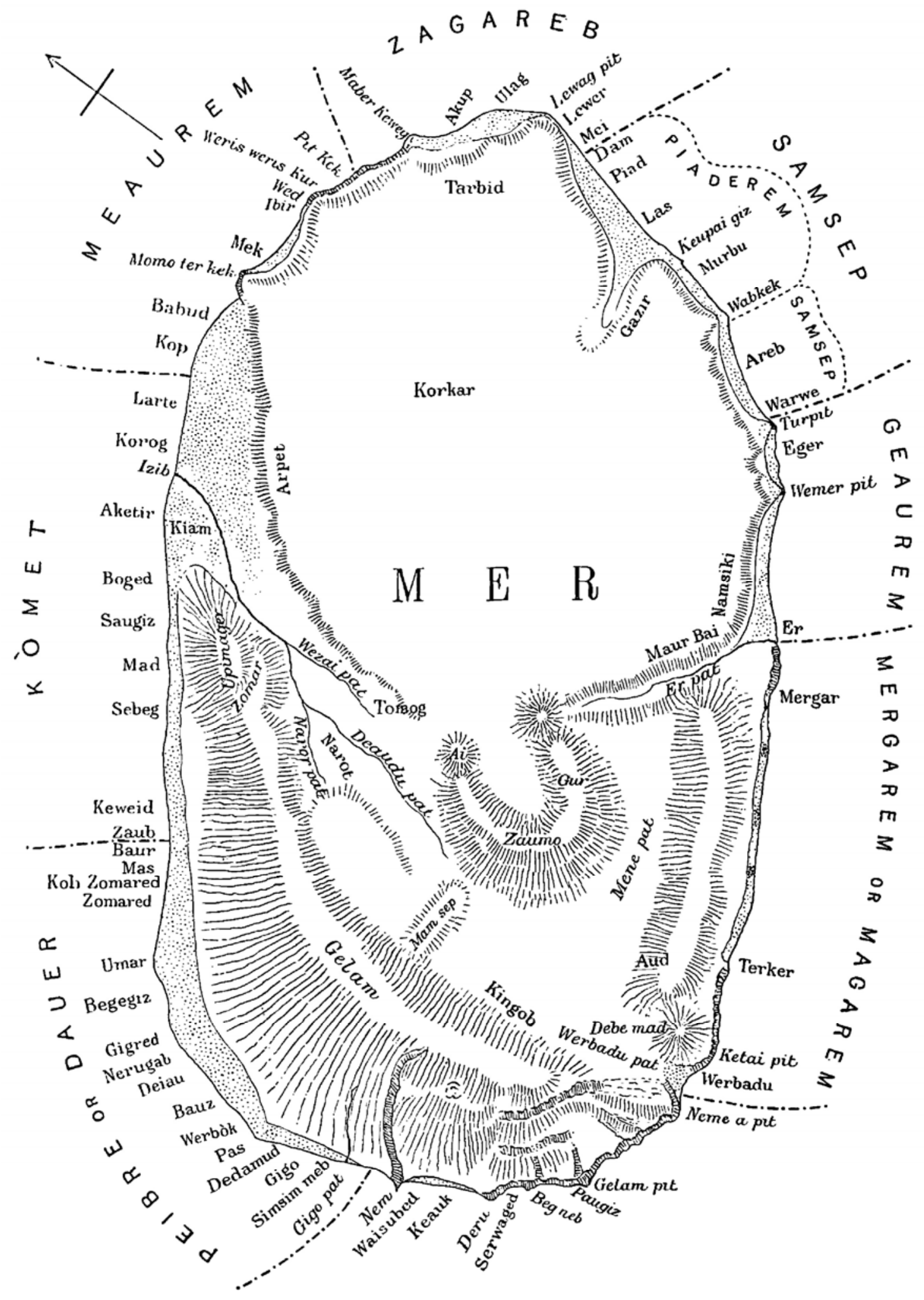

Figure 8. Mer showing clan divisions and fish traps (Haddon 1935:160). 


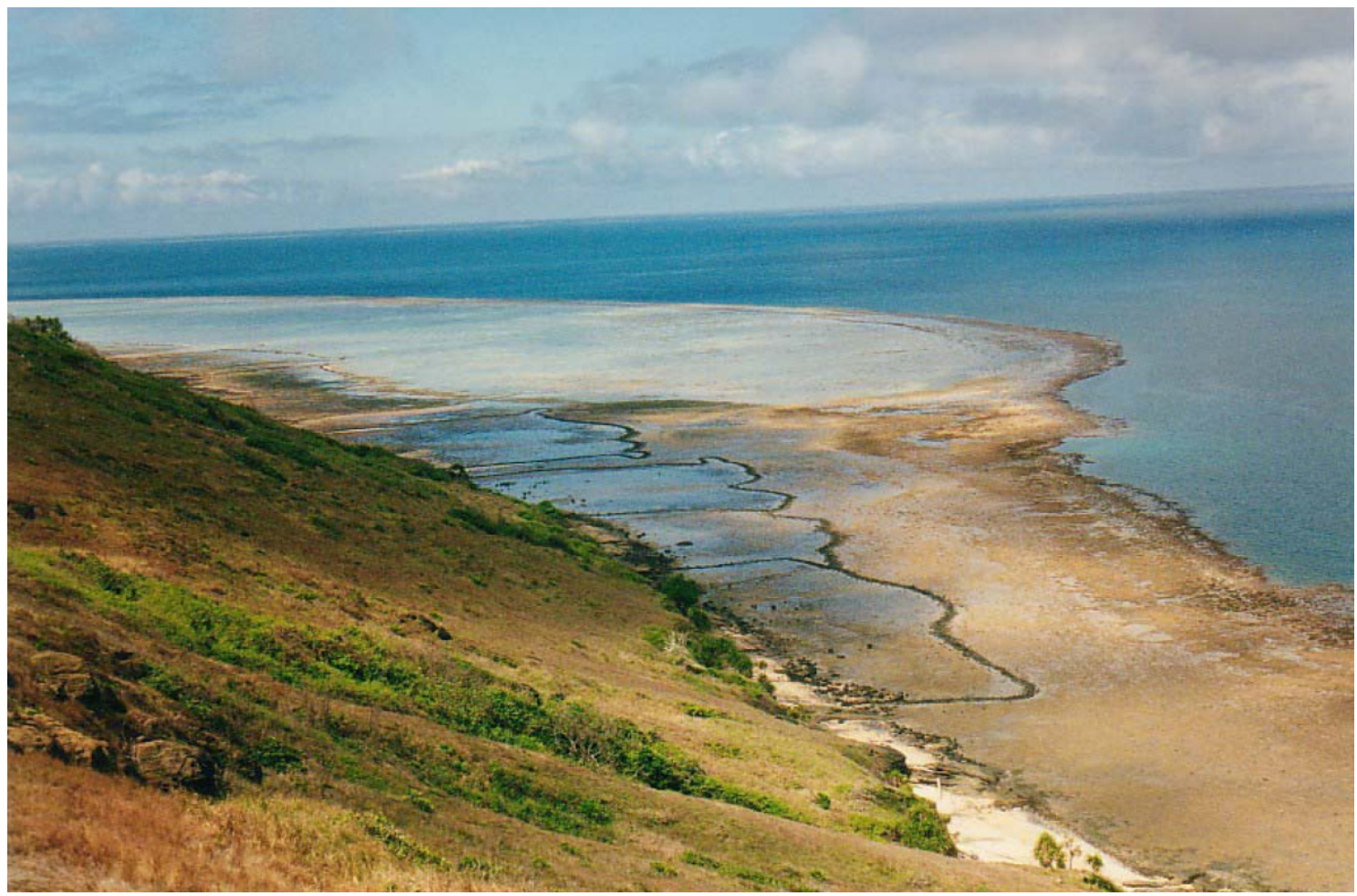

Figure 9. Fish traps on Mer (Carter 2004:140).

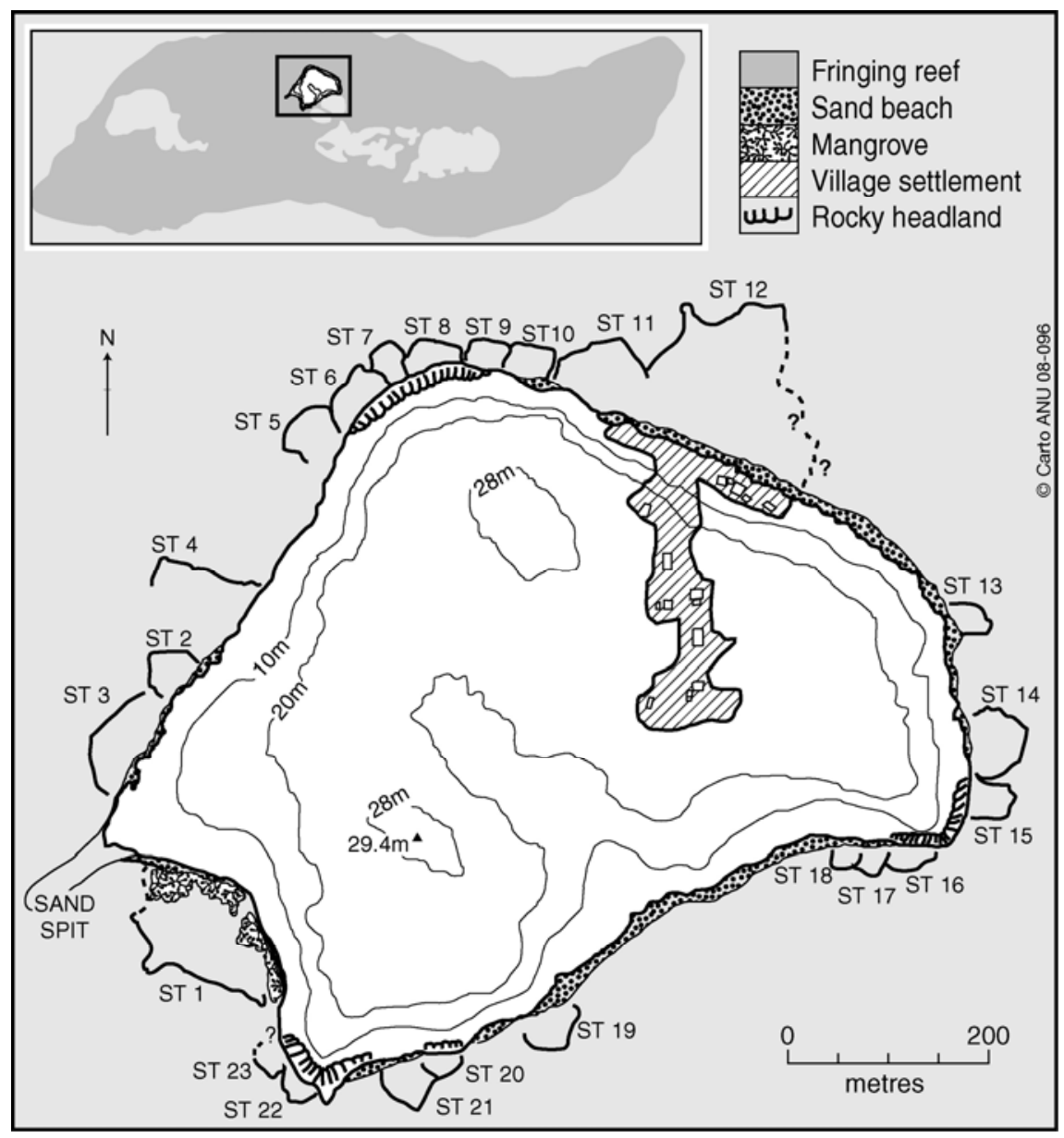

Figure 10. Fish traps on Ugar (Stephens Island) (Barham 2000:Figure 7). 


\section{Gulf of Carpentaria}

Fish traps are also common in areas of the Gulf of Carpentaria (Figure 11). Roth (1901:23), for example, described stone wall traps among the Wellesley Islands:

On Sweers, Bentinck, Mornington, etc., Islands, stone dams are erected along the coast-line in the shape of more or less of a half-circle, the extreme convexity reaching sometimes to as much as 300 yards [274m] from the shore. The majority of these dams are contiguous, and built of pieces of stone ... to a height of from 18 inches [45cm] to upwards of three feet [90 cm], the general contour of the rocky beach being everywhere taken advantage of.

These traps had apparently been modified and extended since 1920 (Colliver 1970:8). Trigger (1987:79-80) notes that some 334 traps (located at 108 sites) are spread over $470 \mathrm{~km}$ of coastline, or on average one trap per $1.4 \mathrm{~km}$, although the density of traps across the region varies considerably. In general most of the smaller islands have a relatively high density of sites (e.g. Bentinck, Sweers, Allen and Forsyth Islands). They are common at the north of Bentinck Island (Tindale 1962:286) and Bird (1996a:5) referred to five traps located in the intertidal zone of the mouth of Mackenzie Creek (listed as AM:A61) while referring to accounts of at least 39 traps on the Island. Sweers and Bentinck Islands have over 150 stone walls arranged into a number of multiple pen traps (Memmott and Trigger 1998; Ulm 2004:Figure 12.2). On Mornington Island there is roughly one site every $20 \mathrm{~km}$ of coastline, on Bentinck one site every $0.9 \mathrm{~km}$ and one trap every $0.4 \mathrm{~km}$ (Memmott et al. 2008). A rough sketch of a site recorded on Mornington Island (BN:A09) is on file and is described as having a seaward length of $120 \mathrm{~m}$ and a width of $80-100 \mathrm{~m}$. It was reputedly still used on occasions when reported in 1983 by Kate Sutcliffe and Peter Smith. Memmott (1996) makes mention of three coastal fish traps (AN:A43, BN:A11 and BN:A21) and a weir (BN:A23) on Mornington Island and these have been listed although their precise location is not recorded. $\mathrm{BN}$ :A11 is described as a semi-circular wall comprising small stones, sand and aggregate. The wall is said to have been made in the Dreamtime by Manhbil. This site is close to BN:A21, described as three upright rocks in the sea. It is known as Nhawalan. BN:A23 is known as Wurukura and is a camp where the nearby river was blocked with traps. A dancing ground and two wells are located near the camp.

Lardil gave the name derdernin to fishtraps while Kaiadilt called them ngarruwarr. They caught not only fish but also turtle and dugong in traps. Other by-products were crabs obtained from the crevices within and underneath the rock walls, oysters from on the rocks themselves, and a range of species of shellfish from the muddy and sandy substrates of the traps (Memmott et al. 2008).

The Lardil people of Mornington, Sydney and Wallaby Islands placed their traps across tidal streamlets and each trap had a gate placed across the streamlet which was left open as the tide rose and was closed with mangrove foliage when it fell. People positioned themselves at these gates with hand nets (mijil), while others drove fish towards the gaps. Weirs (jadman) of poles, bushes and grass were also placed across channels and estuaries. Fish in the traps were speared or captured by hand (Memmott n.d. a, Tindale 1962:286,). The Kaiadilt allowed anybody to use their traps, but among the Lardil it was the patriclan country custodians (dulmada) who gave permission to use traps whenever tidal conditions were suitable (Memmott n.d. a; cf. Robins et al. 1995:83, 1998). A Kaiadilt elder listed six fish species, four kinds of shark and two types of stingray that were easily available for capture when routinely caught behind the trap walls with the receding tide. Lardil believe their traps were shaped by the first Lardil people Maarnbil, Jirnjirn and Diwaldiwal who brought culture and language to Mornington Island (Roughsey 1971). Older people recall the contribution of human labour to building and maintaining some traps. Interestingly, when Kaiadilt were moved from Bentinck Island to a missionary settlement on Mornington Island in the 1940s they built their own fish trap, despite many Lardil traps located in close proximity (Memmott and Trigger 1998:114). Connah and Jones (1983:22) undertook aerial photography of stone wall fish traps on Allen and Bayley Islands and Robins et al. (1995, 1998) have subsequently conducted an extensive survey of the Bayley Point traps and those at Point Parker on the mainland (Figures 1216).

The Bayley Point (Gaabula) trap (AN:A01, previously duplicated as AN:A24) has an inner and outer wall and 8 pens (with a total length of $604 \mathrm{~m}$ ), which Robins et al. (1995:83, 1998) refer to as individual traps. The inner wall has a combined length of $180 \mathrm{~m}$, whereas the outer wall overlapped with the inner wall, extending further south with a total length of $424 \mathrm{~m}$. Most of the traps (pens) are arc-shaped except for trap (pen) 1, which is linear with irregular bends. Fish are speared in these traps and crabs and oysters are harvested from the walls (Figures 15-16). The Bayley Point site has been photographed from the air by Connah and Jones (1983:Figure 13) and it has been mapped and discussed in detail by Robins et al. (1998:Figure 14). Connah and Jones have also photographed sites on Bayley Island (Figure 12) (AN:A02, AN:A03) and Allen Island (AM:A07, comprising four pens) and these are listed on the ICHD but these have not yet been further investigated or mapped on the ground. One site is listed on Sweers Island (BM:A09) but this is from a 1987 map by John Dymock indicating nine separate sites and no further details are provided.

Tindale (in Memmott et al. 2008) noted that on Bentinck Island there were several phases of fish trap building which he related to changes in sea-level. An alternative hypothesis is that a complex of inner and outer rock wall fish traps were used in the same harvesting event upon a falling tide.

In 1880 Captain G. Pennefather observed of the Point Parker traps that they formed 'a succession of walled-in paddocks of many acres in extent' (Boyd 1895:57). Robins et al. (1995:114, 1998) have subsequently described the traps at Point Parker (AM:A59) as comprising five separate pens and two straight walls divided into two separate trap complexes - one trap on the northern side of the point (wall 1), while on the southern side are two single pens and a double pen. The longest continuous wall is $195 \mathrm{~m}$ and the shortest $35 \mathrm{~m}$. Walls 2, 4 and 5 are arc-shaped, wall 1 is V-shaped and walls 3 and 


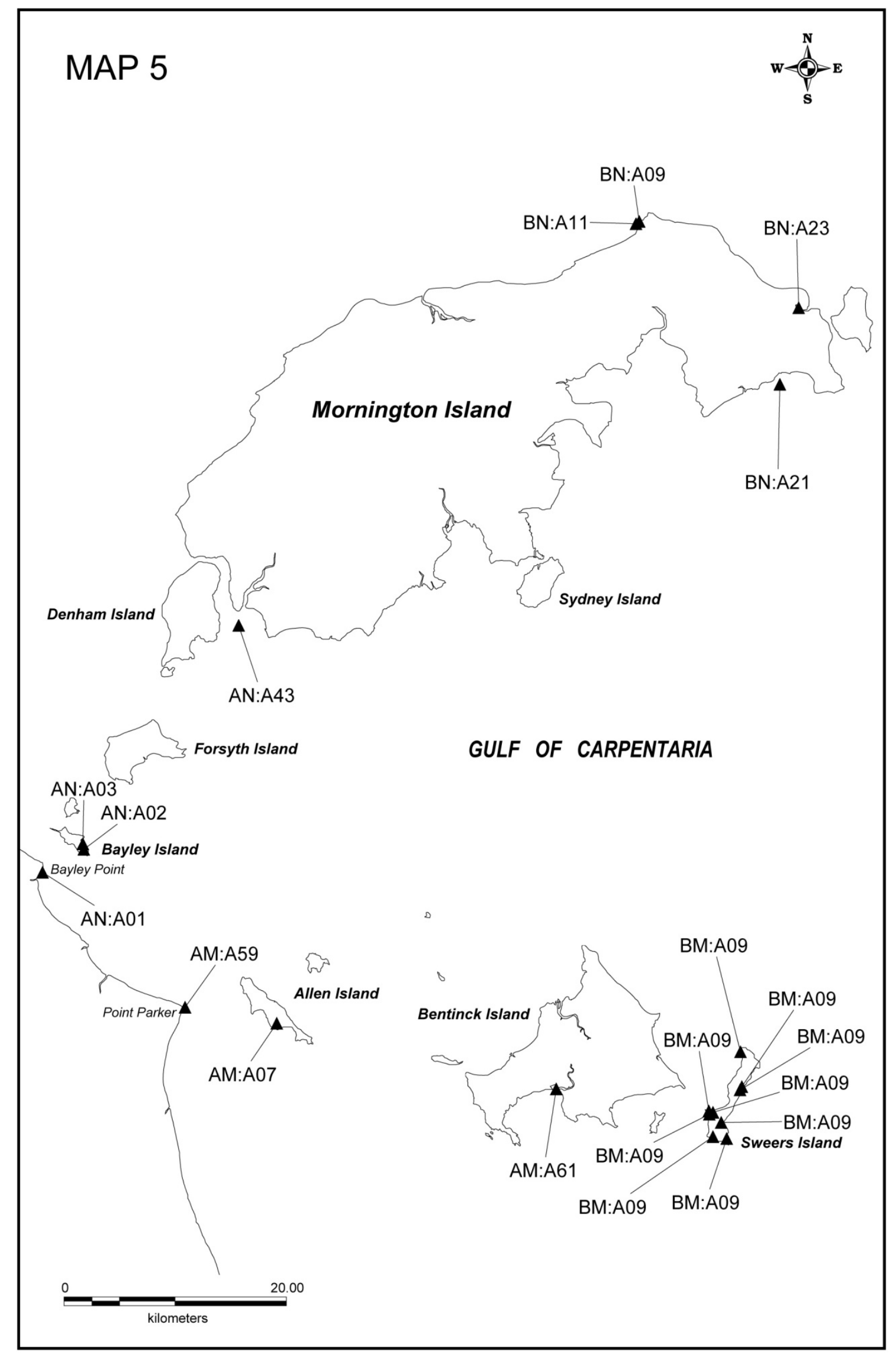

Figure 11. Fish traps registered on the ICHD, Wellesley Islands Region, Gulf of Carpentaria. 


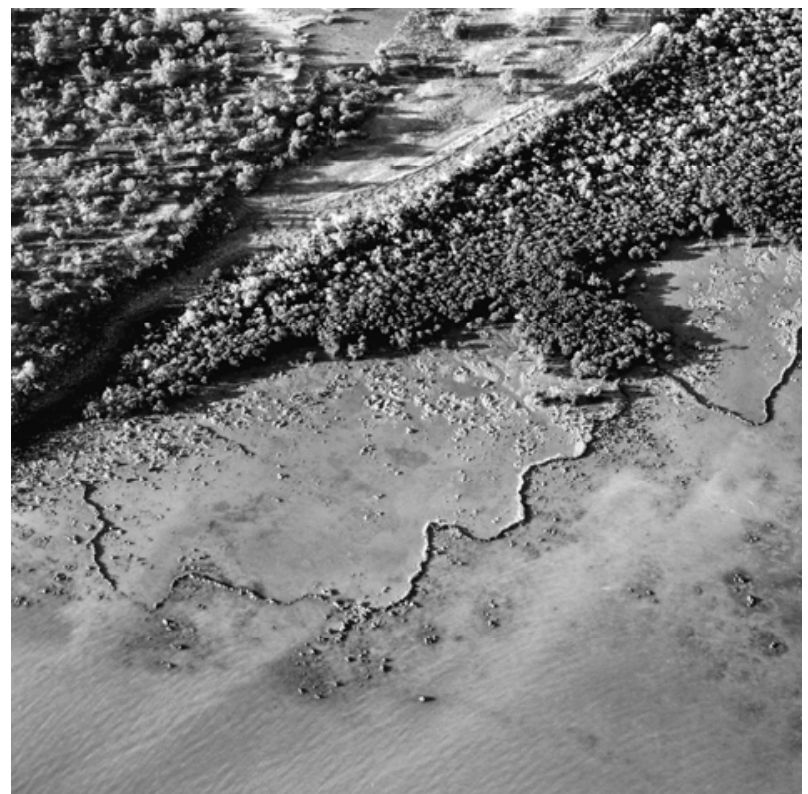

Figure 12. Fish traps on Bayley Island, Gulf of Carpentaria (Photograph: Connah and Jones, 12 May 1982).

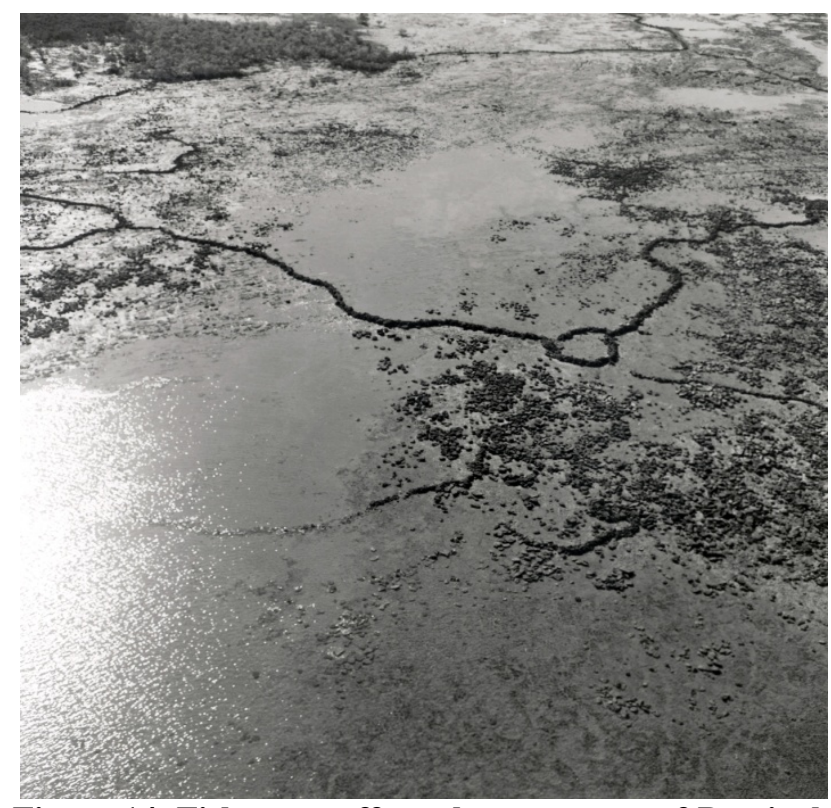

Figure 14. Fish traps off southwest corner of Bentinck Island, Gulf of Carpentaria (Photograph: Richard Robins, Negative 5681).

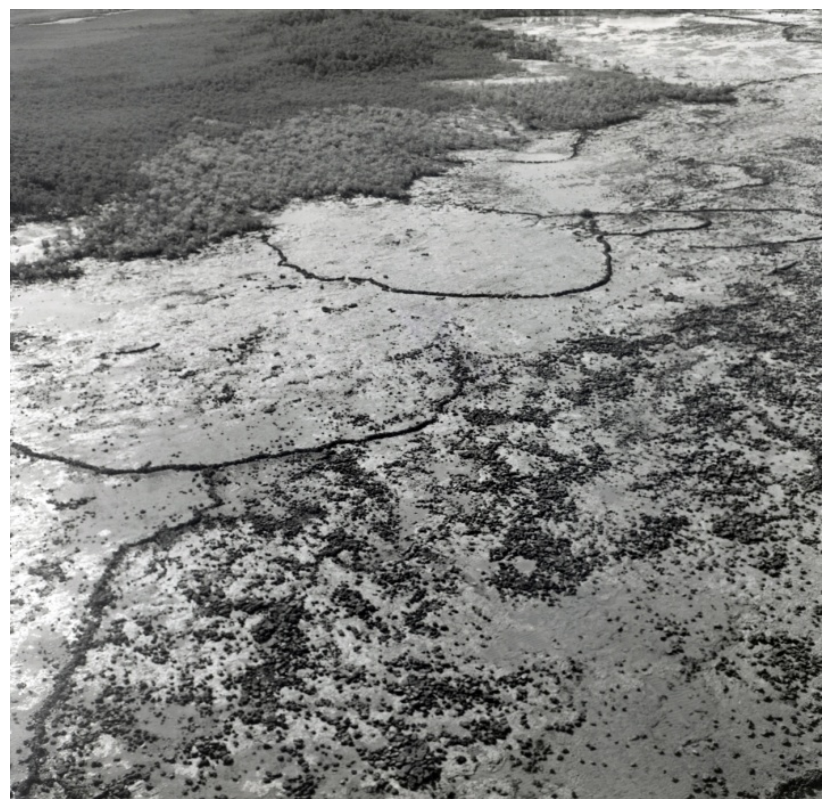

Figure 13. Location B15 (Photograph: Richard Robins, Negative 5681).

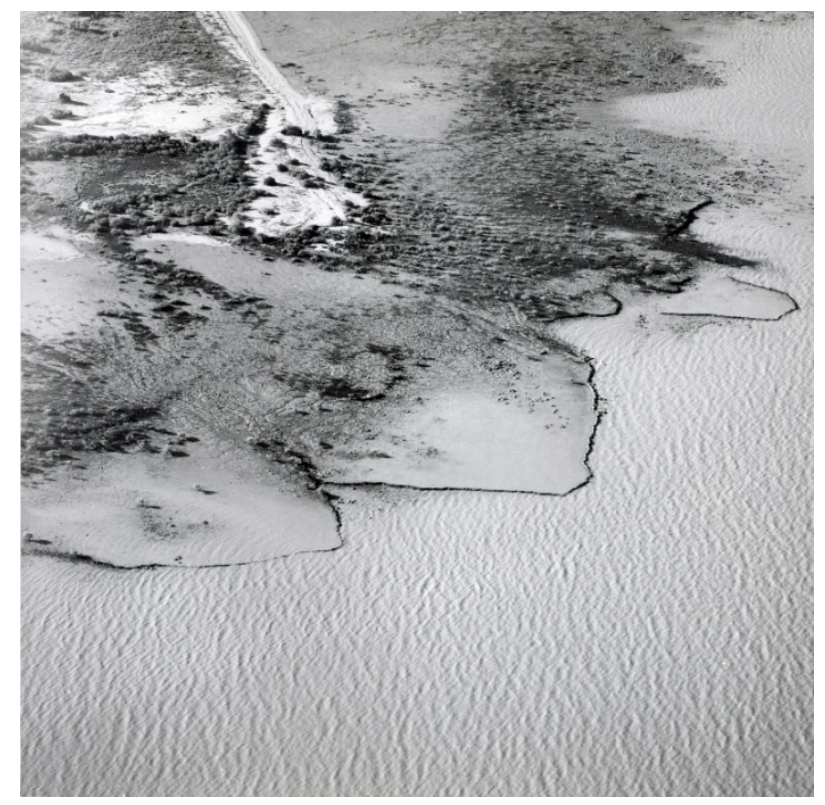

Figure 15. Fish traps at Bayley Point, Gulf of Carpentaria (Connah and Jones, 12 May 1982). 


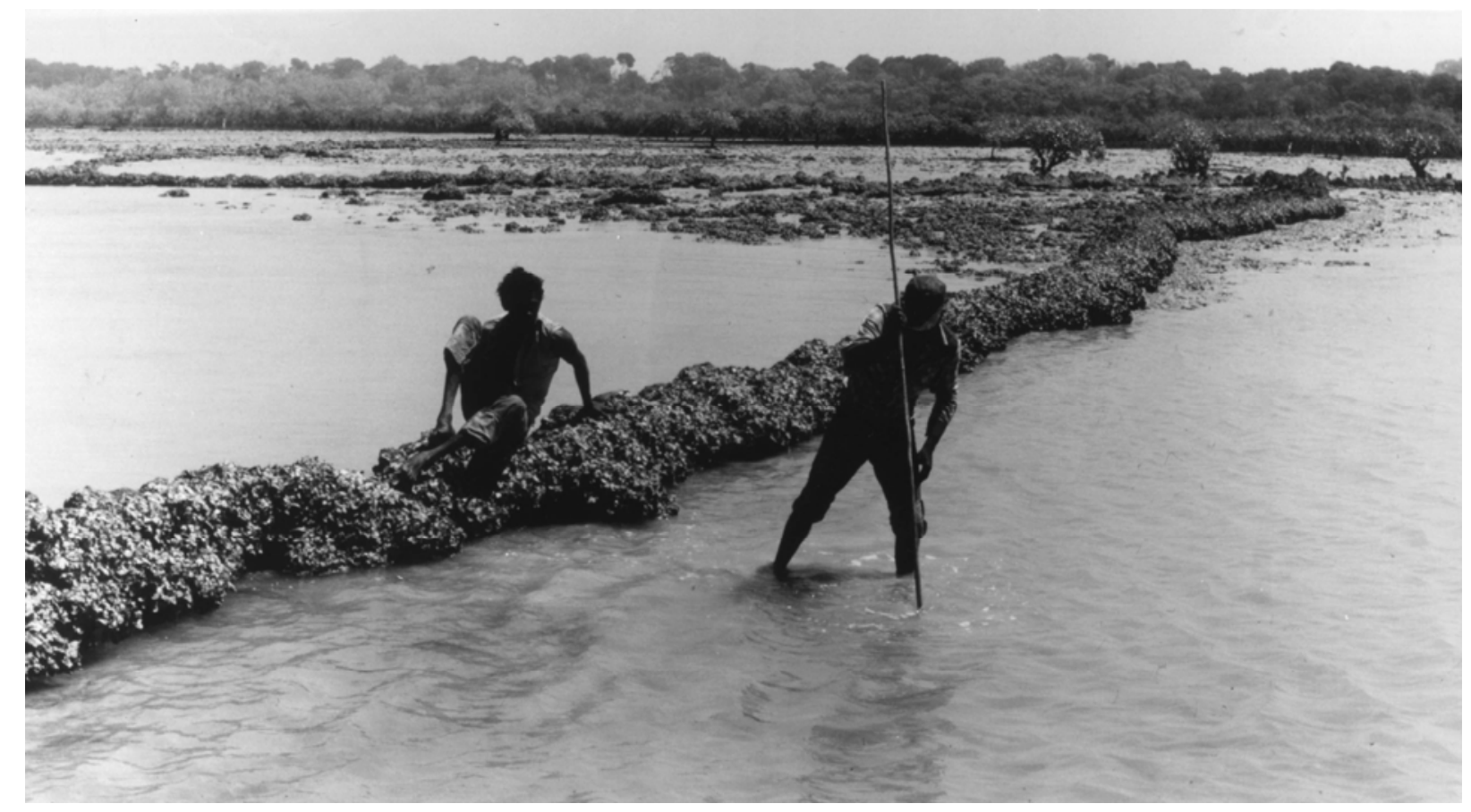

Figure 16. Ronnie Jupiter spearing a crab in a fish trap at Bayley Point, Gulf of Carpentaria (Photograph: Richard Robins, September 1983).

6 (features of pen 5) are straight. Robins et al. (1998:Figure 28) have described and mapped these traps in detail. A diffuse scatter of shell is present on the foredune including oyster (Ostrea sp.) and cockle (Anadara granosa).

In the vicinity of Edward River on western Cape York, Thomson (1936:73) noted that the Koko Tai'yuri [Thaayorre] constructed:

\begin{abstract}
extensive fishing fences on the mud flats of the Gulf; they dam up the flood waters after the rains so that they can the better employ fish poisons in the pools, when the stupefied fish can be speared readily. Organised drives are conducted by big parties armed with nets and spears in the tidal waterways of the rivers, and fish are also taken on lines with hooks made from wood and bone.
\end{abstract}

In a study of the Edward River region, Taylor and Gorecki (in Britnell 1991:8) found brush fish traps in the intertidal zone, which may still be used by members of the local Aboriginal community, although this is not further discussed by Britnell.

\section{Northeast Queensland}

Recorded fish traps in northeast Queensland are concentrated around Hinchinbrook Island (Figure 17). The northernmost trap recorded on the mainland east coast of Queensland is in Quarantine Bay, near Cooktown (EP:A81). This stone wall trap is arc-shaped and was in good condition when recorded in 1978. There was no local knowledge of who built the trap and Britnell (pers. comm., 1996) has subsequently suggested it is nonAboriginal in origin. A survey plan of the site in the ICHD does not assist in determining its origin and further investigation is required. Britnell (1991:56) also reported a trap on the north shore of Cooktown that was built by Aboriginal people after World War II, but which has since disappeared. The mission residents on their return from Woorabinda also constructed a site near Nob Point after
World War II (Britnell 1991:Figure 6.1). Neither site has been allocated a site number and is not included in the database. Further to the south a fish trap is recorded on Snapper Island off Cape Kimberley in far north Queensland (EN:C33). It is reported as having 'huge retaining walls' but no other details are provided. Cribb (1997:Figure 1) has reported the remains of a fish trap at Sunny Bay (FN:B97) near Cairns. He was unable to estimate the dimensions of the site. He also notes that another trap is present around the bay at Giangurra but does not provide further details and the site has not been allocated a site number or included in the site database. A fish trap with $1 \mathrm{~m}$ high walls is reported on High Island (FM:A31) southeast of Cairns, but no other details are provided.

FM:B64 is a weir reported by Duke and Collins (1994b:14,16) at Browns Beach, south of Innisfail. It is described as a natural formation of rock outcrops. It was near a recognised Aboriginal gathering ground that was reportedly built to provide food for those attending gatherings. On the southern side of Clump Point, near Mission Beach, Bird (1994a:18) identified a trap (FM:B42) which covers an area $52 \mathrm{~m}$ in width by $39 \mathrm{~m}$ in length and which is surrounded on all sides by basalt boulders. She also located two poorly preserved stone arrangements in Boat Bay (FM:B44), around the point from the trap, but was unable to identify either arrangement as being conclusively of Aboriginal construction. There are a number of photographs of this site on record but no site plan.

A complex of traps at Scraggy Point and Missionary Bay on Hinchinbrook Island are more widely known and have been described on a number of occasions (Banfield 1909:54; Brayshaw 1977:251; Campbell 1979, 1982; Jones 1961:8; Stephens 1946; Sutton 1986:12; Walsh 1986). Seven traps are recorded at Missionary Bay (FL:A49); each is 'arc'-shaped and stands alone. The trap at Scraggy Point (FL:A23) has a total area of $20,000 \mathrm{~m}^{2}$ 


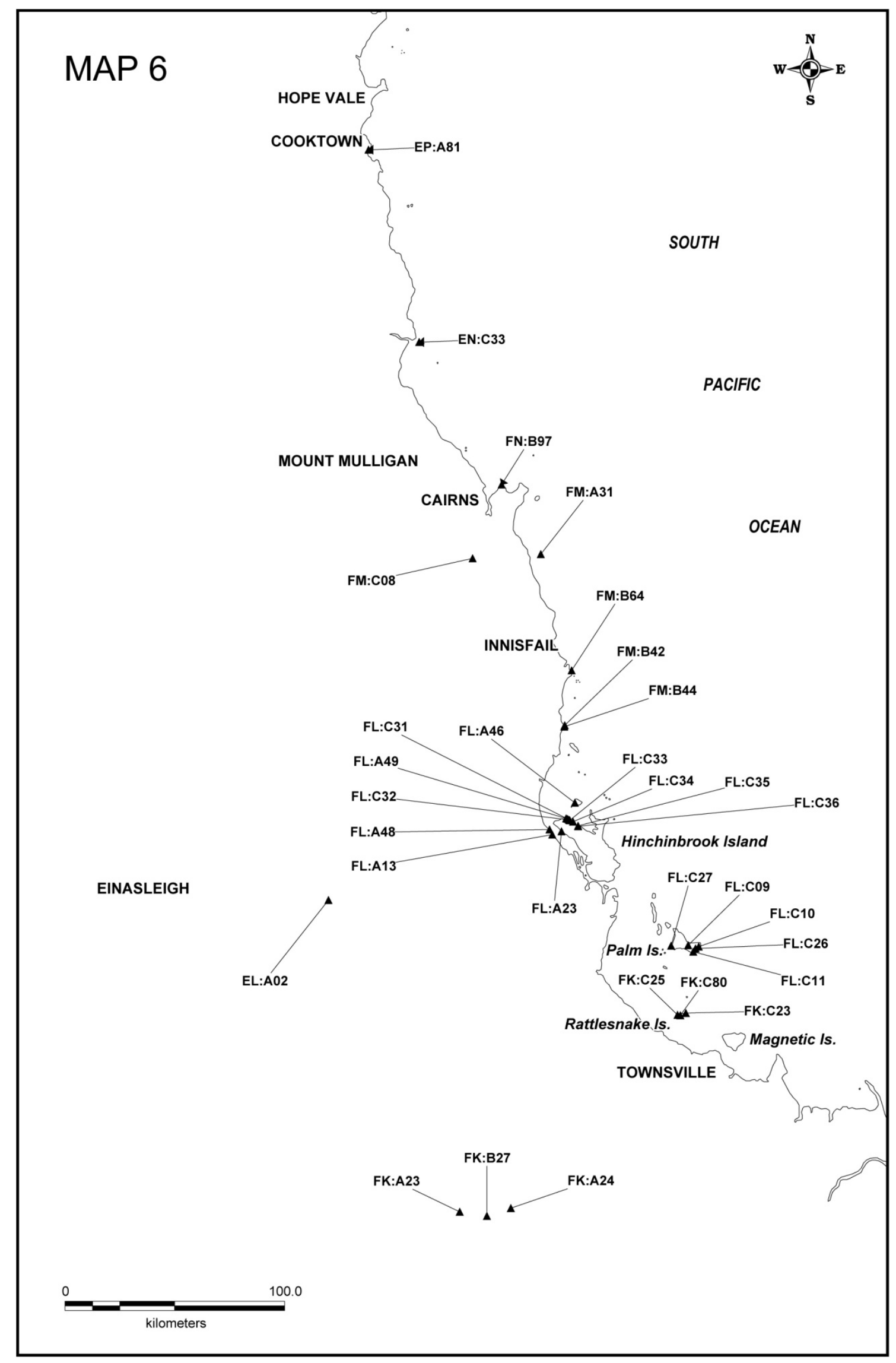

Figure 17. Fish traps registered on the ICHD, northeast Queensland. 
and is described on the site card as consisting of 'loops, pools, breakwaters and funnels' with mangroves covering much of it (Figures 18-19). Campbell (1979, 1982) identified the remains of an earlier trap system below the lowest tide level, which he proposed may have been built at a time of lower sea or land levels and which he suggested could be up to 8000 years old. Stephens (1945) suggested that the Scraggy Point trap had not been used since the 1890s while Walsh (1986:10) thought that the sophisticated design of some of the walls meant they were probably built by early European settlers. Stephens (1946:3) has produced a sketch of the trap at Scraggy Point while Campbell (1979:Figure 3) produced a sketch of these traps drawn from an aerial photograph taken in 1976 and a more complex plan drawn from an oblique photograph taken in 1978 (Campbell 1982:Figure 2). Campbell's (1982) Figure 1 has three fish trap symbols at Scraggy Point and one just to the south now listed as FL:C31-FL:C36. Campbell also reported two fish traps at Oyster Point on the adjacent mainland in the 1970s. These are noted on Campbell's (1982) Figure 1. They have been allocated State file numbers FL:A13 and FL:A48. However, Bird (1994b) could not locate them during fieldwork in 1994. Bird discussed this with Campbell who indicated that the sites were in poor condition when originally recorded. Bird concludes that they may have been covered by mud and sand in the intervening period.

A stone wall trap on nearby Goold Island (FL:A46) has been largely buried by sediment. The trap is set in a drainage channel $40 \mathrm{~m}$ southwest of a freshwater creek mouth. It is arc-shaped and has a double wall at the apex enclosing an area of approximately $4000 \mathrm{~m}^{2}$ (Campbell 1979:27). Maximum wall height of the trap is $52 \mathrm{~cm}$ although most walls have collapsed (Figure 20). Walsh (1986) has produced a useful sketch of this site.

Fishtraps have been reported on Rattlesnake (FK:C25) and Herald (FK:C23) Islands (Hatte and Heijm 1999) and a number of traps have been reported on Palm Island that are apparently regularly used and maintained by members of the contemporary Aboriginal community (Bird 1996b:5, citing N. Heijm). Hatte (1997; Hatte and Manbarra Nagarra Wangarra Aboriginal Corporation 2009) has recorded three sites on Palm Island and one on nearby Barber Island (FL:C09-FL:C11). Site FL:C09 is described as a large fish trap in the corner of North East Bay. FL:C10 is described as a very large fishtrap complex in Horseshoe Bay. Its estimated minimum dimensions are 200m x 300m. FL:C11 is described as a large fish trap on the northern side of Barber Island. Hatte (1997:Figure 1) also notes the presence of other fish traps at Barber Bay (FL:C26) and Casement Bay (FL:C27), but no further details are provided.

A stone wall fish trap approximately $300 \mathrm{~m}$ south of R.M. Creek at Upstart Bay (GK:A52) stretches 15m from nearby mangroves across the mudflats (Bird 1987:123) (Figure 1). Bird indicates that part of the wall is covered by mud and that the trap as a whole might therefore be more extensive. A general locational map of this site is available but no plan. An arc-shaped stone wall trap was located on a tidal flat at Abbot Point (GK:A10), to the south of Cape Upstart. The site was recorded by the Aboriginal Ranger, Bruce Butler in 1980 and the site card indicates a survey and sketch map were attached but they have not been located. GK:A10 has more recently been relocated and described by Bird (2009:57-59; Bird refers to the site as JU2). It was located $500 \mathrm{~m}$ west of the location recorded on the DERM Indigenous Sites Database. It is located in the intertidal zone fronting a remnant beach ridge containing shell midden material. It is arc-shaped and $40 \mathrm{~m}$ in length. It is well-preserved with walls standing approximately 40 to $50 \mathrm{~cm}$ in height. It is constructed from local boulders from the sandy tidal flats with rocks of roughly uniform size placed between some of the larger naturally positioned boulders. The structure appears to be still functioning as a fish trap on the receding tide, although there appears to be some sediment build-up on the landward side of the wall, which may be reducing its overall efficiency (Figures 21-23).

In the same location Bird (2010) recorded further fish traps to the west of GK:A10 which are not recorded on the DERM database. Shark Bay 1 (SB1) is described as an arc-shaped fish trap. It is located close to the beach on the edge of the intertidal sand flats around $9 \mathrm{~m}$ from high water mark. It is not well-preserved being impacted by a substantial build-up of sediment. The wall is $20 \mathrm{~m}$ in length. The walls of the trap are partly collapsed but some of the boulders are cemented together with oysters. Two lines of stones are described as associated with SB1; one is $7 \mathrm{~m}$ in length, the other 8 to $10 \mathrm{~m}$ in length.

Shark Bay 2 (SB2) is described as curved and extending $15 \mathrm{~m}$ in length. It is composed of large boulders with more uniformly sized, smaller boulders placed between the larger ones. The walls have in places partially collapsed. The full extent of the landward and seaward margins of the trap was difficult to detect (Bird 2010).

A stone wall trap at Adelaide Point, near Bowen (GJ:A37), is described by Hill (1981:9) as arc-shaped with long arms at the landward end, and broken at the seaward end. It is $1.5 \mathrm{~m}$ in width and approximately $6.5 \mathrm{~m}$ in length.

Seven ambiguous arrangements of stone have been recorded on Mine Island, near Cape Upstart. Lines of stones are located around the edge of the island in the shape of arcs, funnels and straight walls. These lines are no more than one stone high and individual stones are spaced apart. Milne (1990:95) argued that the stone lines may have been foundations for organic walls, although she was not able to rule out the possibility that they were stone arrangements serving a different purpose to that of fish traps. Andrew Border (pers. comm., 1996) who has inspected the site believes they are stone arrangements rather than fish traps. Barker et al. (2010) suggests they are ceremonial arrangements (see also McNiven 2003). Brayshaw (1990:160) also doubts they are fish traps suggesting water only reaches the site at exceptionally high tides, although this may not always have been the case and that the stones are too widely spaced to be effective as fish traps. Milne (1990:Figures 4.2-4.10) has provided plans of many of the stone arrangements but they do not appear to be fish traps and remain enigmatic.

In a few areas of north Queensland traps and weirs have been reported that were made of organic materials. Roth (1901), for example, described such a weir at Princess Charlotte Bay as being 100 feet (30m) long and formed of a composite cross-piece along which dozens of thin switches from 8-10 feet (2.4-3m) were placed. Upright forked timbers supported the 5-6 logs that made the cross-piece which reached the height of flood levels. 


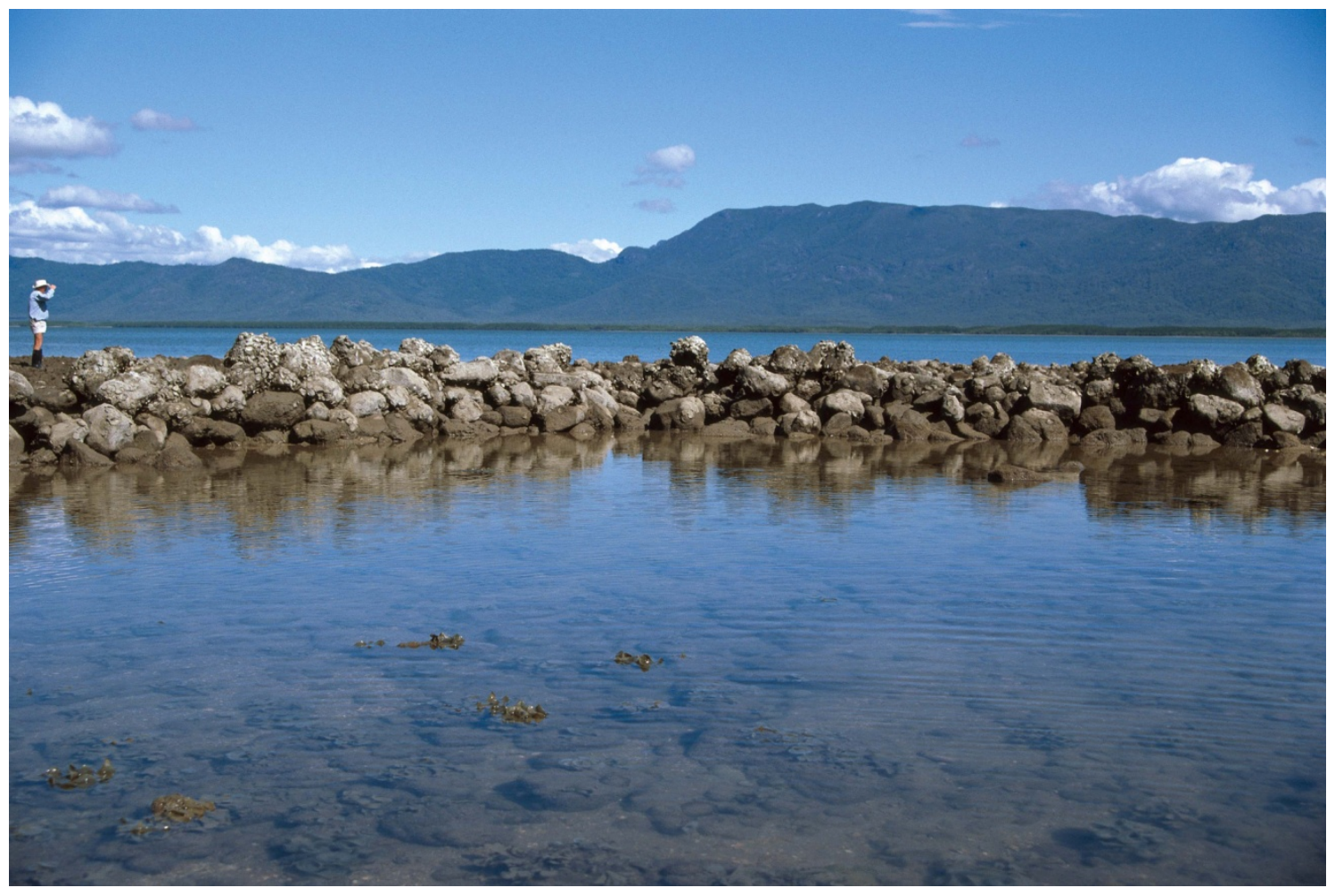

Figure 18. Fish trap FL:A23 at Scraggy Point, Hinchinbrook Island (DERM ICHD Slide Collection).

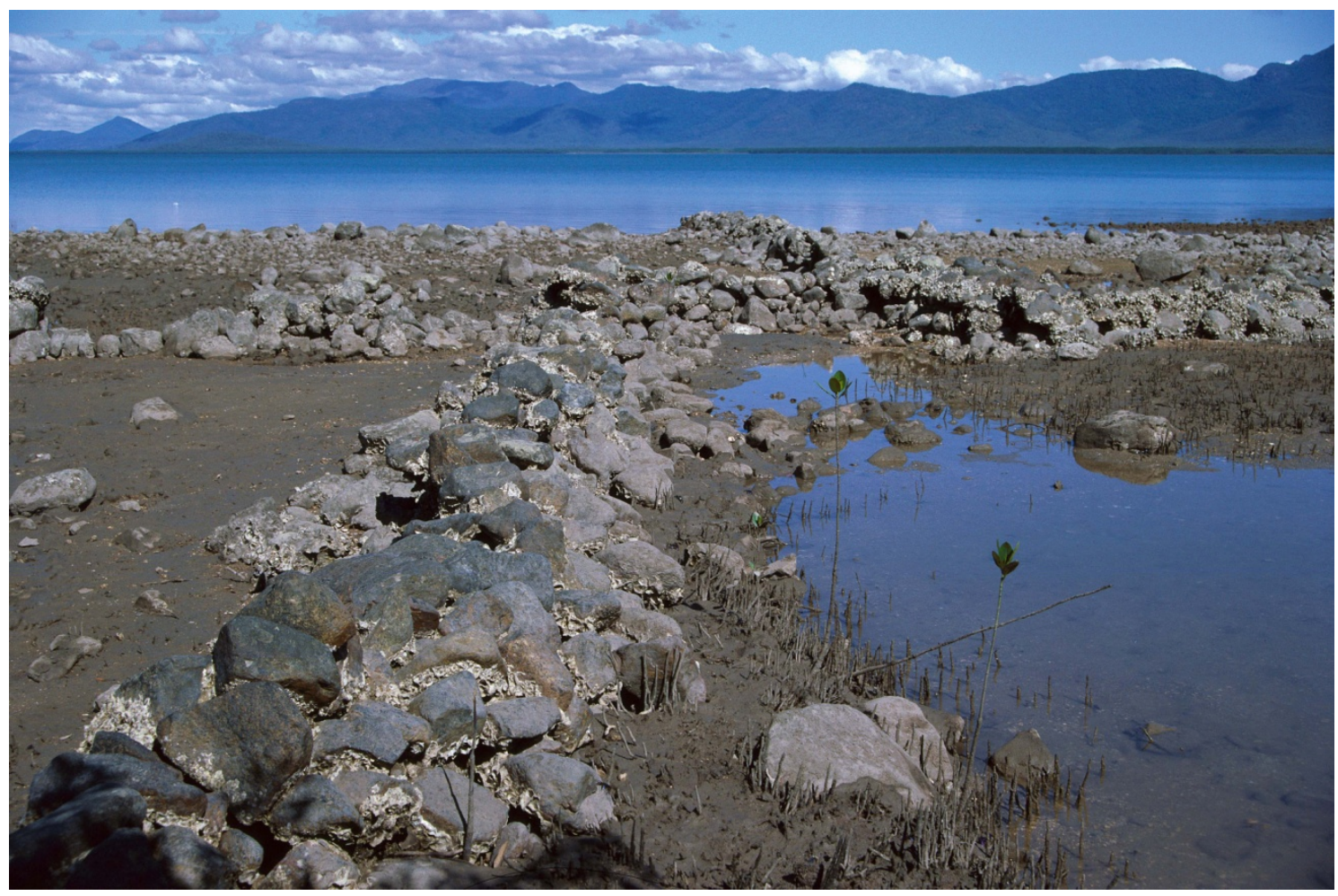

Figure 19. Fish trap FL:A23 at Scraggy Point, Hinchinbrook Island (DERM ICHD Slide Collection). 


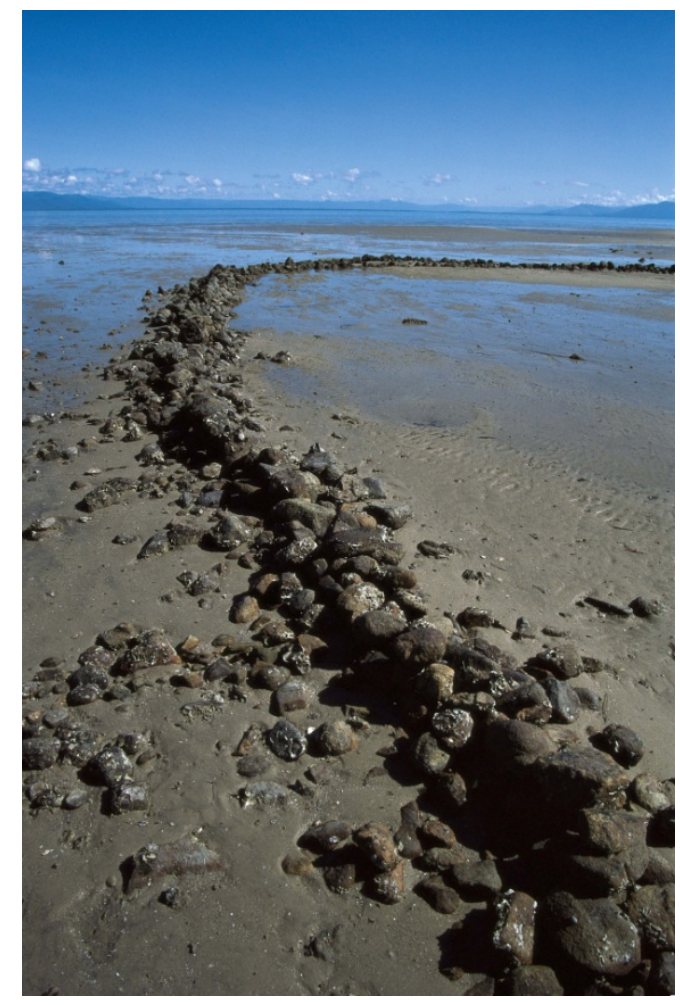

Figure 20. Fish trap FL:A46 on Goold Island, near Hinchinbrook Island (DERM ICHD Slide Collection).

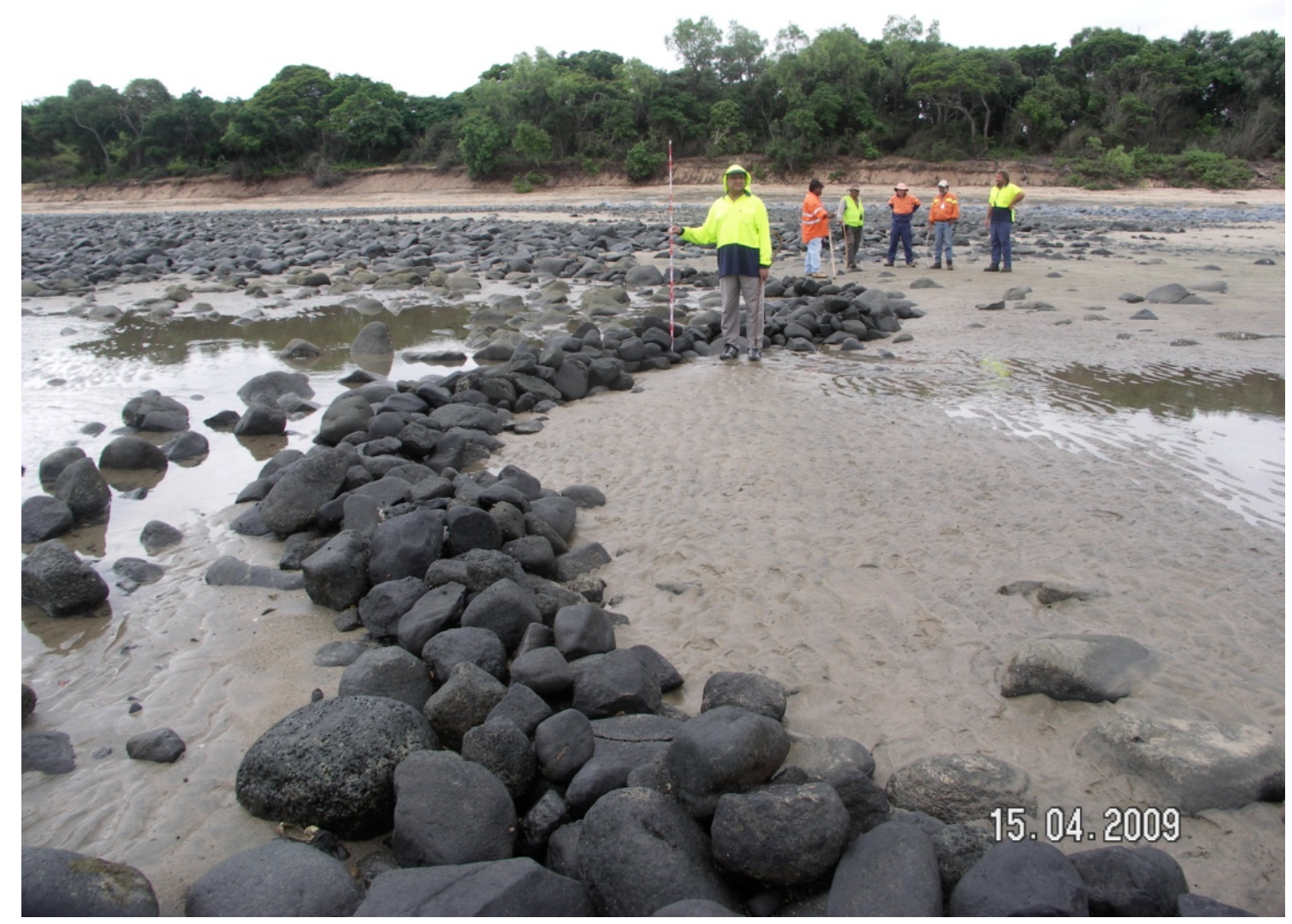

Figure 21. Fish trap GK:A10 at Abbott Point, Mackay region, 14 April 2009 (Bird 2009:Plate 171). 


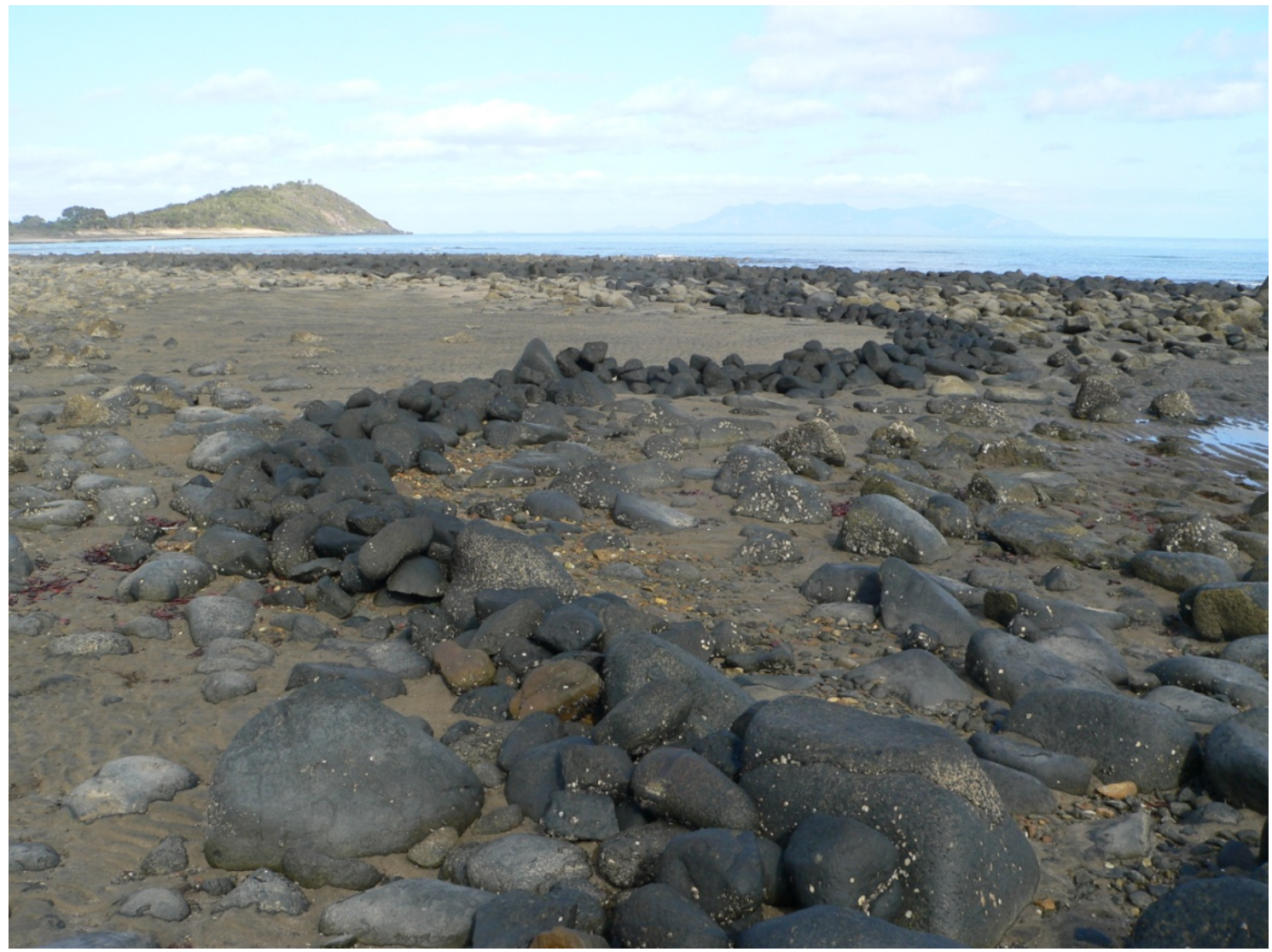

Figure 22. Fish trap GK:A10 at Abbott Point, Mackay region (DERM ICHD Slide Collection).

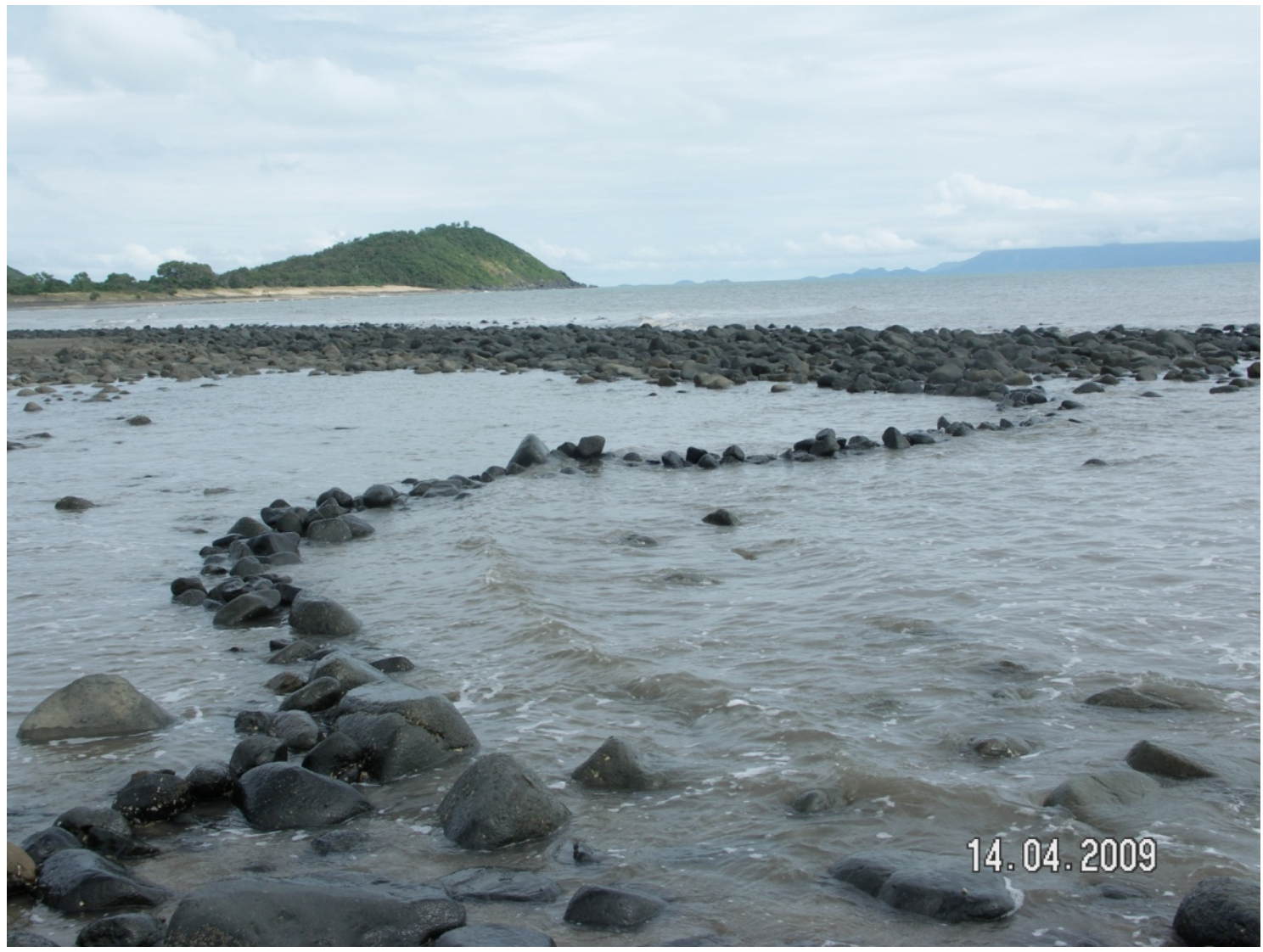

Figure 23. Fish trap GK:A10 at Abbott Point, Mackay region, 14 April 2009 (Bird 2009:Plate 19). 
The switches that were firmly stuck in the mud rested at an angle on the upstream side of the weir to resist water movement. Nets were fixed at the extreme edges of the weir to trap fish trying to escape, and as the water receded fish were speared or captured (Roth 1901:23). Hale and Tindale (1933:110) also observed an organic weir at Bathurst Head, Princess Charlotte Bay. It comprised a brush wall approximately $7.5 \mathrm{~m}$ long that dammed a mangrove creek. Further to the south on Dunk Island, Banfield (1977:141) indicated that traps were made from lawyer cane (Calamus sp.). Jukes (1847:86-87) observed an organic weir being used by women, while travelling by boat along a tidal creek at Upstart Bay in the 1840s, and Bird (1987:50) has subsequently identified this watercourse as Lefthand Branch Creek, a tributary of Saltwater Creek.

\section{Central Queensland}

Eighteen fish trap sites are recorded on the ICHD for central Queensland (Figures 24-25). Barker and Bernard (2007) have recently undertaken an assessment of some of these fish traps located between Bowen and Sarina and their observations have been incorporated here. Barker (1992a:33) has recorded a stone weir (HJ:A76) at Woodwark Bay that extends $15 \mathrm{~m}$ across a tidal creek (Figure 1). In an earlier survey Barker (1988:8,10), also located stone wall fish traps at Midge Point (HJ:A29) and at the southeastern point of Covering Creek (HJ:A36). The Midge Point trap is of square shape, $16 \mathrm{~m}$ in length by $14 \mathrm{~m}$ across with an average wall height of $70 \mathrm{~cm}$. The trap at Covering Creek, is a single stone wall placed between two natural rock walls. The stone wall is aligned northeast, is $13 \mathrm{~m}$ long and $60 \mathrm{~cm}$ tall at its highest point and rests on a rock platform approximately $240 \mathrm{~m}$ east of the high water mark. Discussions with local residents and the presence of a graded road to the Midge Point trap led Barker (1992a:10,12) to conclude that non-Aboriginal fishing people built it. A graded road leading to the Covering Creek trap also led Barker to conclude it was of non-Aboriginal construction. Barker found enough difference between the Midge Point and Covering Creek traps and the weir at Woodwark Bay to argue that the latter was of Aboriginal construction. Another stone structure at Midge Point (HJ:A06) revisited by Barker and Bernard (2007) is recorded as concentric in shape with a maximum wall height of $40 \mathrm{~cm}$ and rocks heavily encrusted with oyster. Barker (1992a) also reports the presence of another fish trap at Woodwark Bay (HJ:A03) with dimensions 50m x 50m. Barker and Bernard (2007) discuss two sites - one at Adelaide Point (Duck Creek), the other at Dingo Beach - which are of European origin. Barker (1992b) has reported a circle of stone (HJ:A96) on the mangrove mudflat of South Repulse Island. It is described as easily recognised as a fish trap but no other details are available.

Winsor (1982:162) reported a stone wall trap as having existed on Brampton Island, in the Whitsunday Group, but there is no other record to verify this claim and the site has not been allocated a site number. A stone wall trap is also reported on Green Island (HJ:A34) as arcshaped with walls that extended $200 \mathrm{~m}$ from a natural rock wall. The built wall was between $30-45 \mathrm{~cm}$ high and the middle section was missing, although whether this was a breach or intentionally designed is unknown. Site plans are not available for this site. McGarry (1987:Plate 3), who reported the site but did not observe it, obtained the information from local residents.

South of Midge Point two stone wall traps have been recorded at Mentmore Beach (HJ:B03) and Dewars Point (HJ:A15). The Mentmore Beach trap is described as extensive with walls $60-90 \mathrm{~cm}$ high, while the Dewars Point trap is partially covered by sand. However, no survey plans of these sites are available. HJ:A14 is a fish trap at Seaforth Beach reported by McGarry (1987) and recorded in more detail by Barker and Bernard (2007). The trap comprises a concentric line of individual stones with a maximum wall height of $10 \mathrm{~cm}$. A trap on Rabbit Island (HJ:A35) was reported as a ruined 'arrowhead' trap, but McGarry (1987:54-55) could find no evidence of it. Andrew Border (pers. comm. 1996) has subsequently located it and considers it is a modern trap made of wood.

A stone wall weir at Sand Bay, Cape Hillsborough (HJ:A18), was recorded by Border and Hall (1994:2-3) as stretching approximately $65 \mathrm{~m}$ across the mouth of a small intertidal cove enclosing an area of $5500 \mathrm{~m}^{2}$. Border and Hall suggest the wall was originally linear in shape and that much had disappeared. A useful sketch of this site can be found in Border and Hall (1994:Figure 2). Barker and Bernard (2007) report a wall height of $30 \mathrm{~cm}$ (Figures 26-27). Another weir (HJ:A07), said to be associated with nearby middens, has been recorded in a small inlet at Cape Hillsborough, and was described as a line of stones that sealed two rock outcrops. The recorder of HJ:A07 did not have a map of the region and therefore estimated the weir's location. The descriptions of HJ:A18 and HJ:A07 are so similar they might be assumed to be the same site (Andrew Border, pers. comm., 1996), however, further investigation is required.

A trap at Reliance Creek, as well as weirs at McCready Creek, Pioneer River and Gallagher Creek, has been described by McGarry (1987). The trap at Reliance Creek (HH:A04) was a series of stone walls approximately 3036cm high. It was not actually seen by McGarry. HH:A16 at Sunset Bay was also not seen by McGarry (1987). It was described as a scatter of stones over an estuarine flat. Little remains of a site (HH:A19) reported at Eimeo Beach and it cannot be conclusively considered to have been a fish trap. The weir at Gallagher Creek (HH:A17) was described as a single wall that was later divided by a track and its original length was estimated to be $68 \mathrm{~m}$. The weir at McCready Creek (HH:A15) jutted 5m into a 10mwide rock pool and is claimed to have been partly dismantled after World War II. Little remains of what was reported to have been a series of fish traps in the area. McGarry described two weirs at Pioneer River, one was $2.9 \mathrm{~m}$ long and enclosed a rock pool while the second was upstream of weir 1 and was a stone wall $6.3 \mathrm{~m}$ long by 1.76m wide (both listed as HH:A20). Border (1994:15) was unable to locate either weir despite a number of surveys of the region. Anecdotal evidence from a Walkerston resident, however, suggests that a South Sea Islander (George Efrey or Outrey?) used a rock fish trap at the site. McGarry has provided rough sketches of HH:A15 and HH:A17 on the site cards for these sites but they are not informative. Bird (1996b:4) has described a stone wall arc-shaped fish trap at Hay Point (HH:A75). The trap is near the shoreline and runs about $60-65 \mathrm{~m}$ across intertidal mud flats. It had a maximum width of 


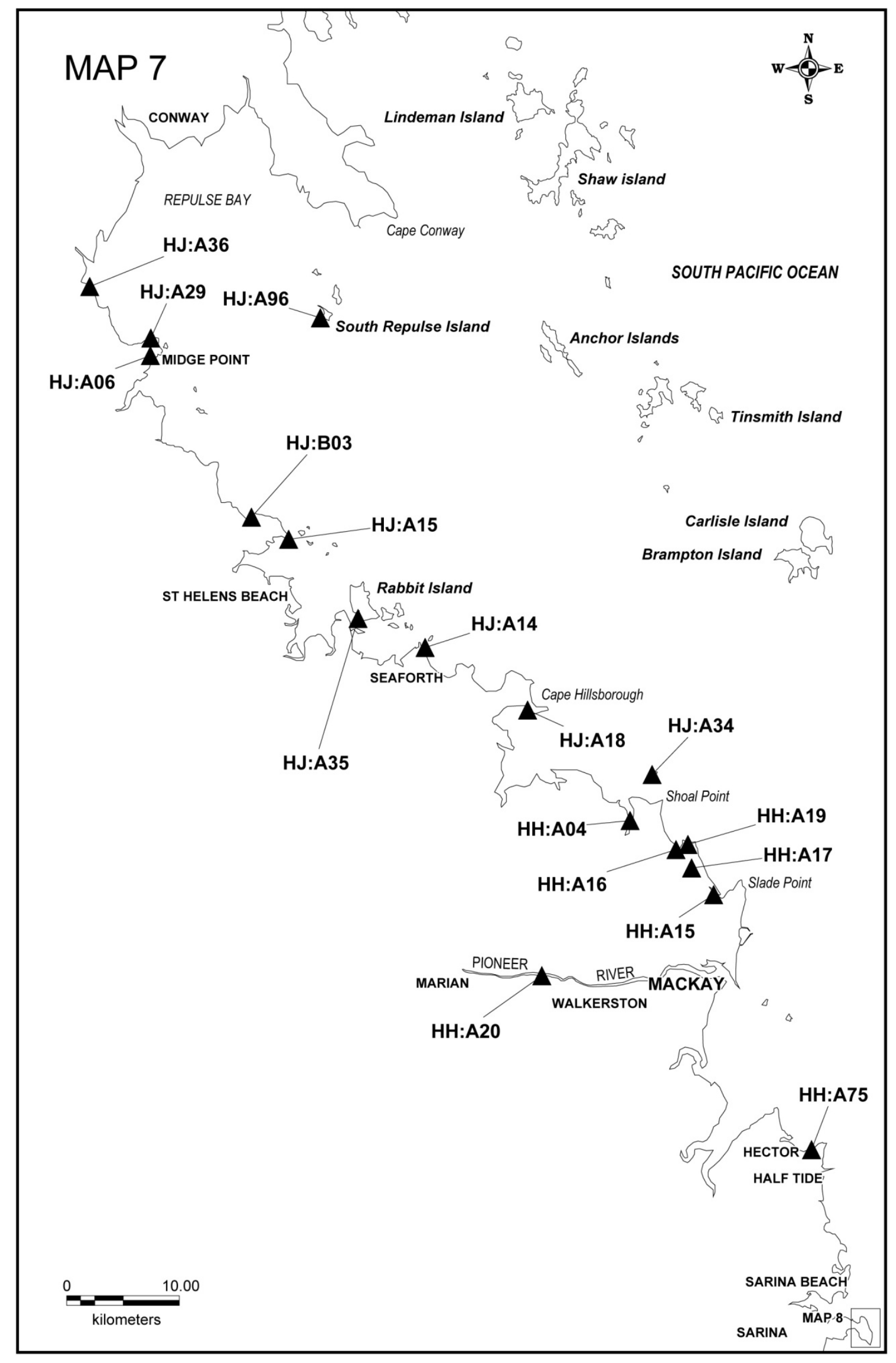

Figure 24. Fish traps registered on the ICHD, Central Queensland Region. 


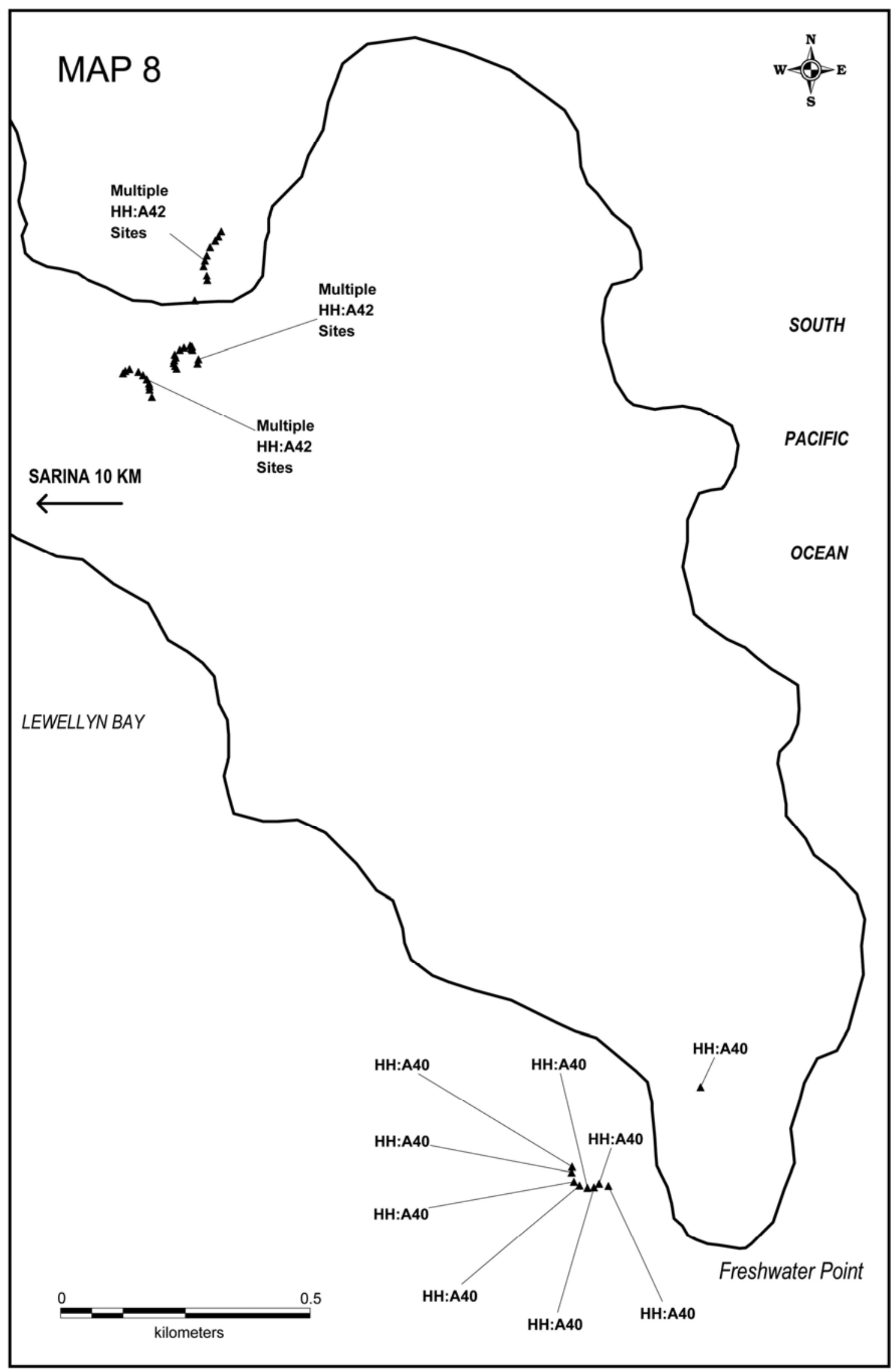

Figure 25. Fish traps registered on the ICHD, Freshwater Point, Central Queensland Region. 


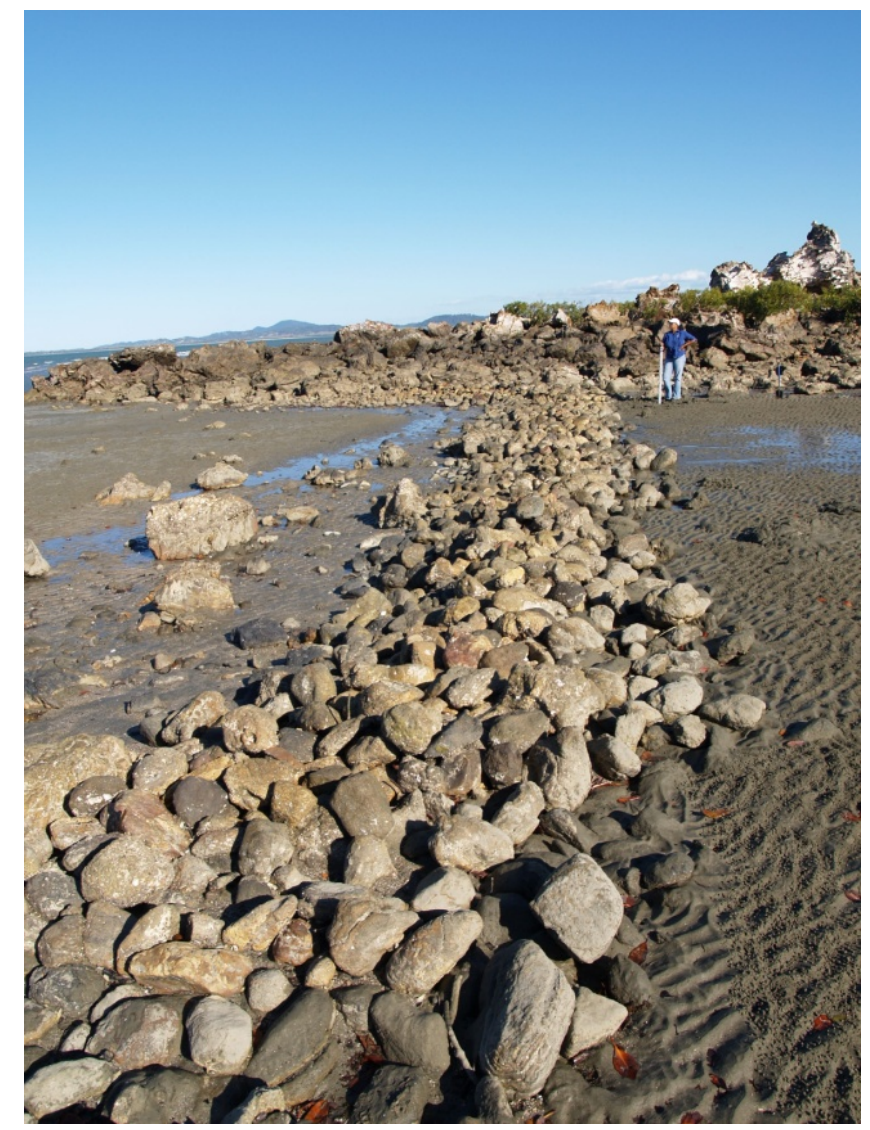

Figure 26. Fish trap HJ:A18 at Cape Hillsborough (Barker and Bernard 2007:Figure 15). Note spread out/deflated nature of stones.

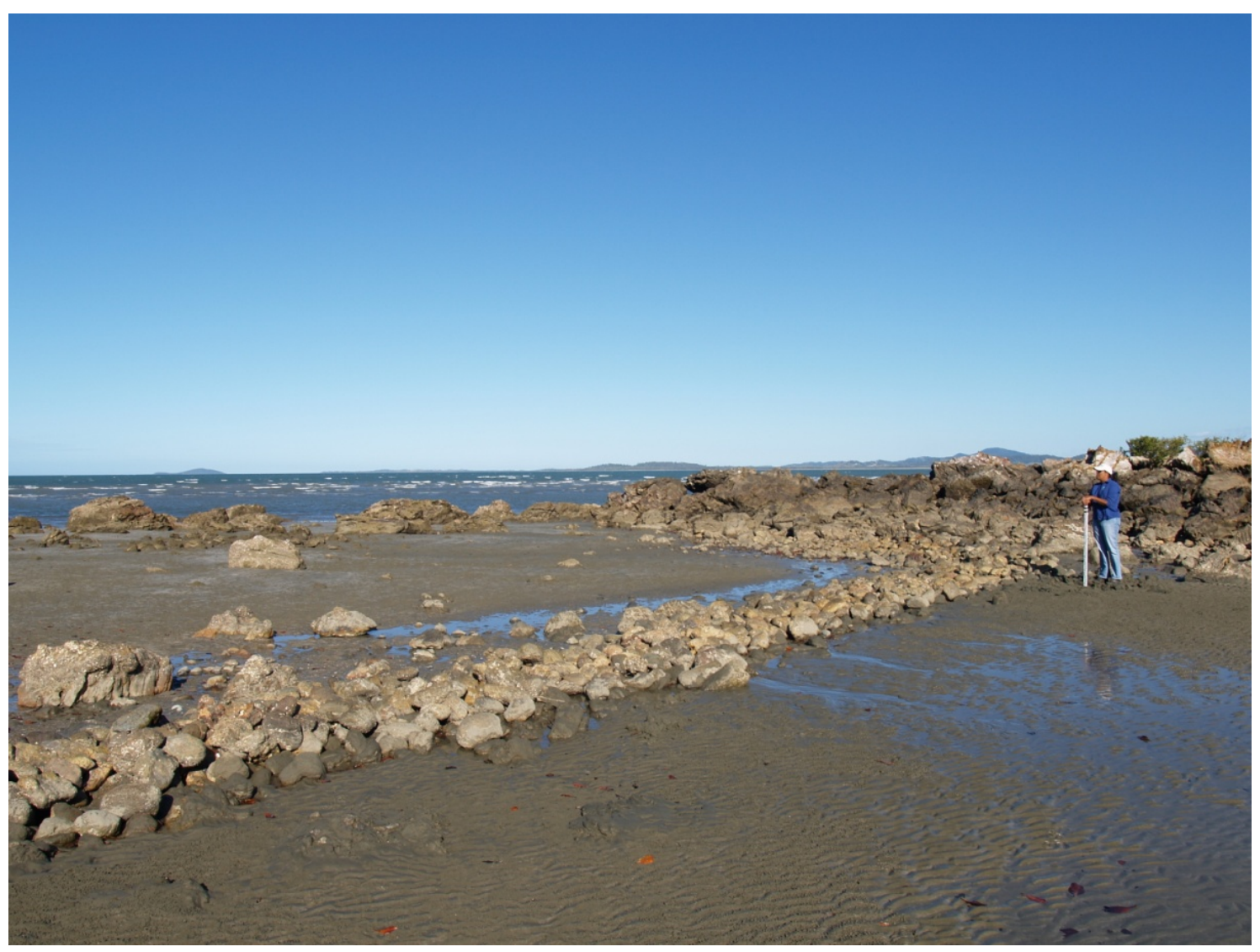

Figure 27. Fish trap HJ:A18 at Cape Hillsborough (Barker and Bernard 2007:Figure 16). 
$2.2 \mathrm{~m}$ and the walls had a maximum height of $40 \mathrm{~cm}$. The walls appeared to have partially collapsed over time and wave and tidal movement had moved individual stones and several sections of the wall. Despite this the site was described as being in relatively good condition. There are photographs of this site but no site plan.

Three traps have been recorded at Freshwater Point, south of Mackay (Figure 25). The first (HH:A40), on the southern side of the Point, was arc-shaped, comprising two pens made of stone and was estimated at $90 \mathrm{~m}$ long by $40 \mathrm{~m}$ wide with a maximum wall height of $20 \mathrm{~cm}$ (Barker and Bernard 2007). Barker and Bernard (2007) conducted a test excavation of the inside of the trap wall reporting that the stones sit on mud and sand underlain by green clay. The clays sit on a rocky rubble layer (Figures 2829). The second (HH:A42) comprised two stone wall traps approximately $80 \mathrm{~m}$ apart. Both traps were arcshaped and were located in the intertidal zone near the mouth of Sarina Inlet. Border has provided useful sketches of both these sites on his submitted site cards. Barker and Bernard (2007) report a maximum wall height of $20 \mathrm{~cm}$. There are multiple fish traps in the area of Freshwater Point with imprecise recording of known trap locations as clear in the plotting of HH:A42 on the inland of the peninsula (Figure 25) (see also Barker and Bernard 2007). Barker and Bernard (2007) also report a fish trap at Fig Tree Point.

Border (1992:22) located two walls of stone (HH:A74), which extended $80 \mathrm{~m}$ from the beach to the inter-tidal zone, on West Hill Island, but he was reticent to identify these traps as being Aboriginal constructions. Creighton (1984:15, 127), mentioned a stone wall weir in a creek at the end of Long Beach on South (Great) Keppel Island and a trap in Mazie Bay Creek, on North Keppel Island. Rowland who has undertaken extensive surveys of the island has not located either of these traps (see Rowland 2008 for references). Rowland did observe a small linear stone wall at Mazie Bay but this was confirmed by a local resident as being built in the 1930s to shelter his boat. The sites on the Keppel Islands have not been allocated site numbers and are not included in Appendix A.

South of Mackay the coastline appears to be largely devoid of stone traps and weirs. Apart from an arc-shaped stone wall trap at Richards Point on Rodds Peninsula (KF:A12) (Burke 1993:46) and a nearby trap at Mort Creek (Ulm 2006), there are no other traps or weirs reported south of Mackay to as far as Burnett Heads (Figure 1). It is unclear whether this is due to the extensive development of this coastline or is a true reflection of absence. Further surveying of the coastline would clarify the situation. There is no plan but a rough sketch map of the trap at Rodds Peninsula available. Ulm (2006:Figure 2.12; see also Ulm and Lilley 1999:Figure 13) presents a photograph of this feature and describes this is as 'a probable stone-walled tidal fishtrap' (Ulm 2006:101) but notes extensive disturbance of this area associated with heavy mineral sand mining in the 1970s.

Ulm (2006:97-98) reports a probable stone walled tidal fish trap on the western margin of Mort Creek, $4 \mathrm{~km}$ south of the Richards Point trap. The oyster-encrusted rocks appear to be anthropogenic extensions of the larger boulder outcrops which extend towards the creek from the shore. The rocks on the intertidal flats are much smaller than those under the canopy of the adjacent mangrove fringe. The portability of these smaller rocks and the absence of larger boulders in this area suggested to Ulm that the rocks were transported to extend oyster habitats and/or to form a stone-walled trap. The feature consists of several tiers of rocks, with lower tiers visible through the top of the mangrove muds. The rocks form two low, linear banks which are raised above the level of the surrounding flats by accumulating muds. Although the two arcs curve towards each other, they do not meet. The southern arc appears to be broader than the northern one. The abundance of fish remains recovered from the adjacent shell midden deposits provided Ulm with circumstantial evidence for an Indigenous origin of the feature. On the basis of 12 radiocarbon dates available for the adjacent deposits, Ulm argues that the site, including the fish trap, was little used after 2000 years ago.

\section{Southeast Queensland}

In southern Queensland stone wall fish traps have been recorded at Burnett Heads (KE:A22) and on Woody Island (KD:A17) (Figures 1 and 30). No plans of these sites are on record. The Woody Island trap is described as permanently underwater in the intertidal zone (Frankland 1990:33; McNiven 1992:21; see also Lauer 1979:68). The Burnett Heads trap is situated just inside the mouth of the Burnett River and is arc-shaped with at least two pens. The wall has two sections, the first is $30 \mathrm{~m}$ long and the second $15-20 \mathrm{~m}$, with a break of about $15-20 \mathrm{~m}$ separating these sections. The wall is $1 \mathrm{~m}$ at its highest point but averaged less and intermittently joined up with natural rock outcrops. It is unclear whether the trap is of Aboriginal or South Sea Islander origin (Godwin 1992), although Foley $(1992: 18,22)$ argues they are Aboriginal constructions. Godwin (1992) reported the presence of many South Sea Islander-built walls in the Mon Repos area, which could bear upon any interpretation of the Burnett Heads trap.

McNiven (1994) recorded five stone wall fish trap complexes at Booral (Figures 30-32). No description of Trap Area 1 (KD:B23) (apart from an illustration, McNiven 1994:Figure 2.3), which is located 100m south of Area 2, is provided. Trap Area 2 (KD:A15) consists of five walls arranged in two major groups. A southern group consisted of four 20-40m long arc-shaped walls linked to a number of natural rock walls while to the north was a single 90m long arc-shaped wall, intersecting natural walls. Trap Area 3 (KD:A14) consisted of four continuous and discontinuous arc-shaped walls varying in length between 30-40m. Each constructed wall intersected a natural wall, while the two northern (seaward) walls intersected each other. The northernmost of these walls had a 2m wide gap. Trap Area 4 (KD:A13) consisted of three arc-shaped walls which varied in length from 'a few' up to $70 \mathrm{~m}$ and larger walls intersected at least one natural wall. Trap Area 5 (KD:B24) had two separate arcshaped walls. One was $25 \mathrm{~m}$ long and both ends joined up with natural rock walls while the other wall meandered for $70 \mathrm{~m}$ through mangroves before connecting with a natural wall. It is possible that the walls McNiven reported were the remnants of a larger, more extensive trap complex. McNiven (1994: Figure 2.3, Figure 4.1) has comprehensively mapped these sites. 


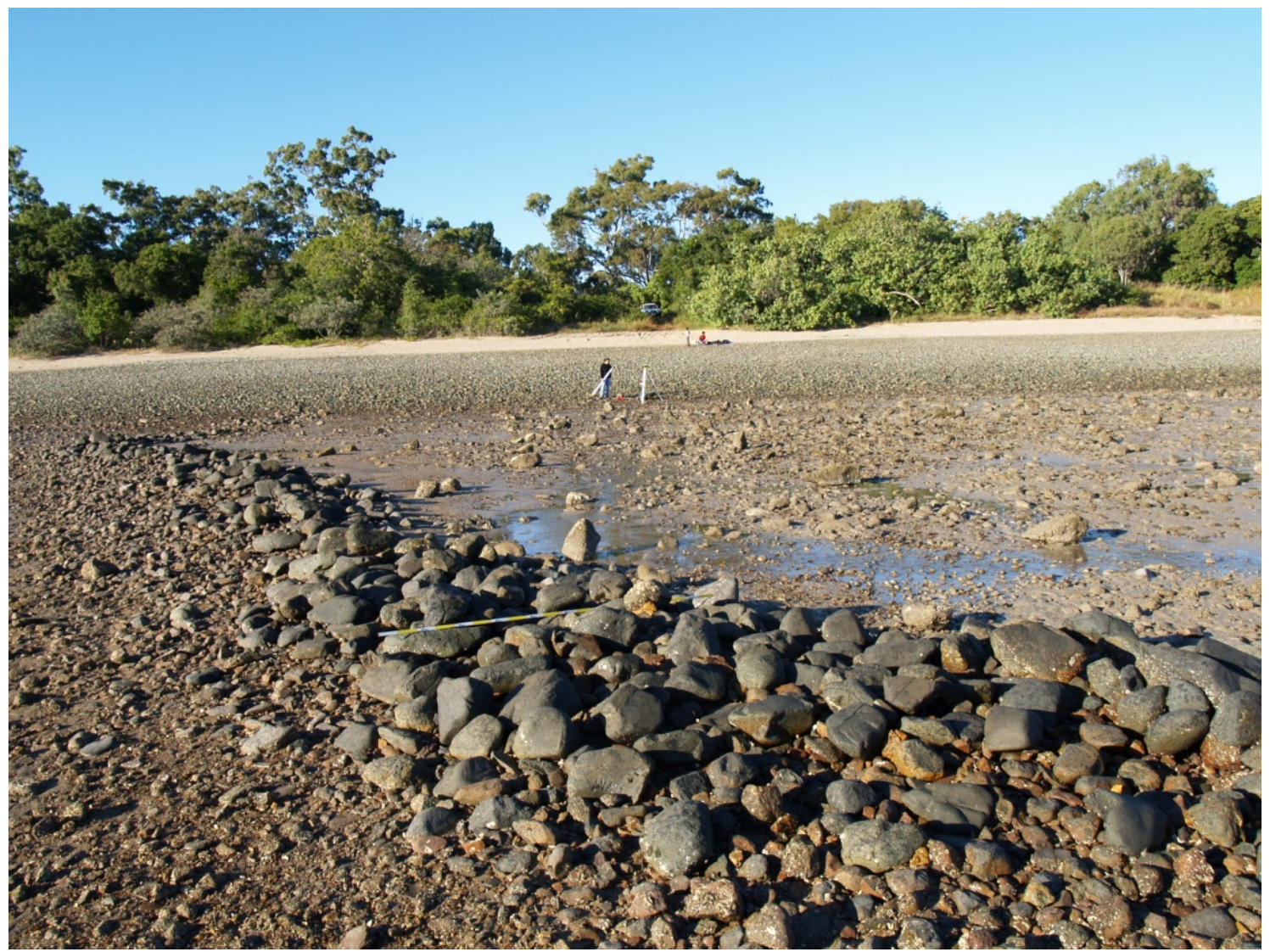

Figure 28. Fish trap HH:A40 at Freshwater Point (Barker and Bernard 2007:Figure 19).

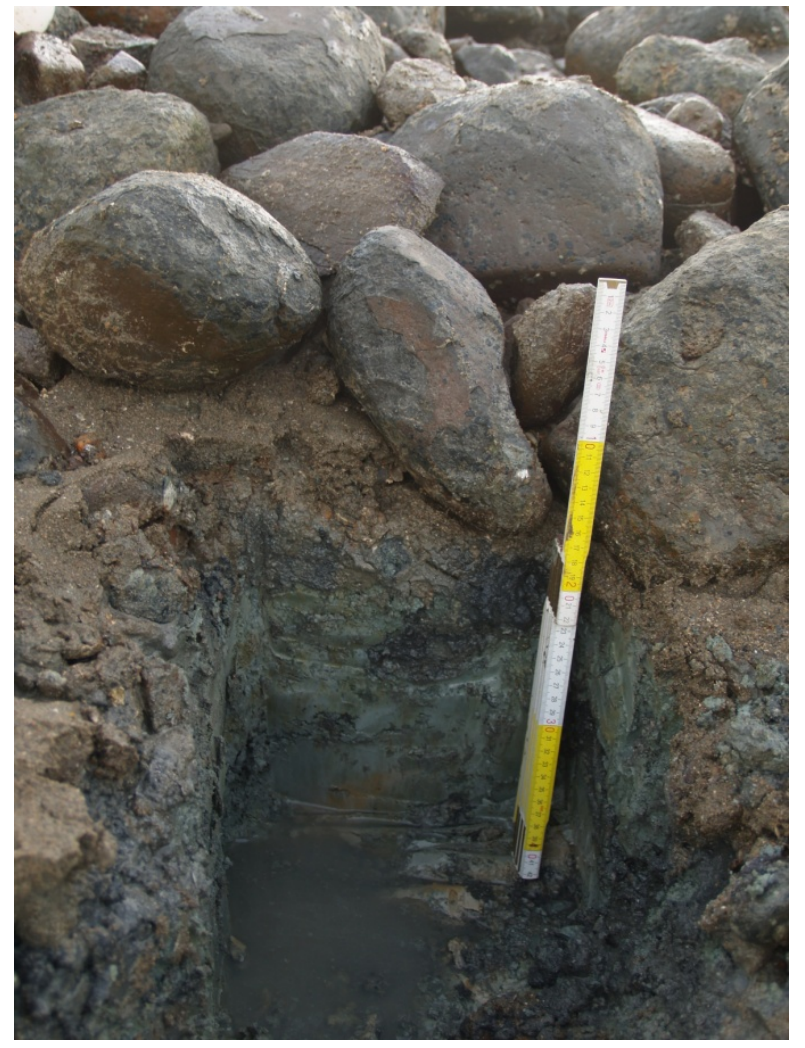

Figure 29. Excavated section of fish trap HH:A40 at Freshwater Point (Barker and Bernard 2007:Figure 21). 


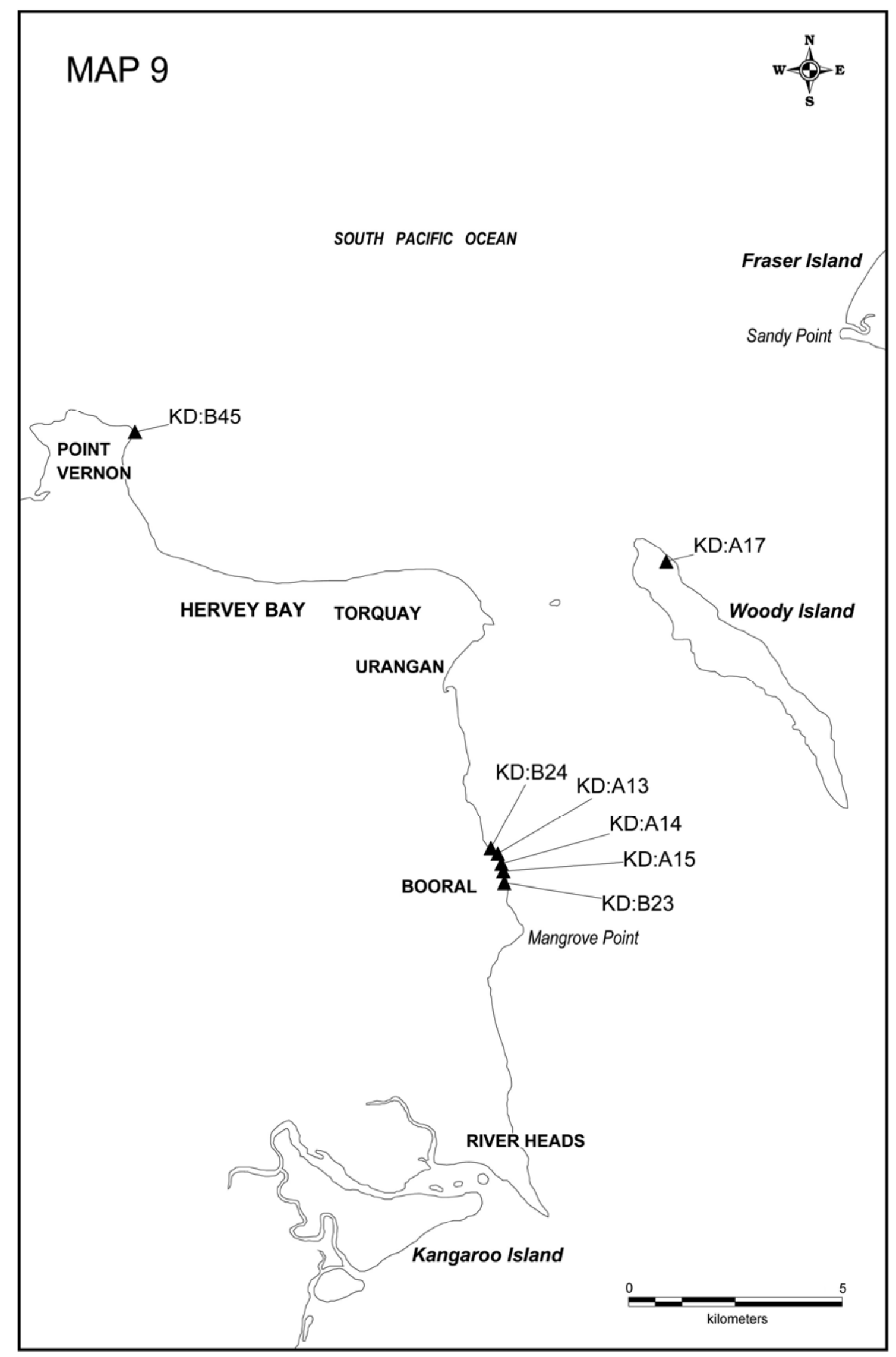

Figure 30. Fish traps registered on the ICHD, Great Sandy Straits, southeast Queensland. 


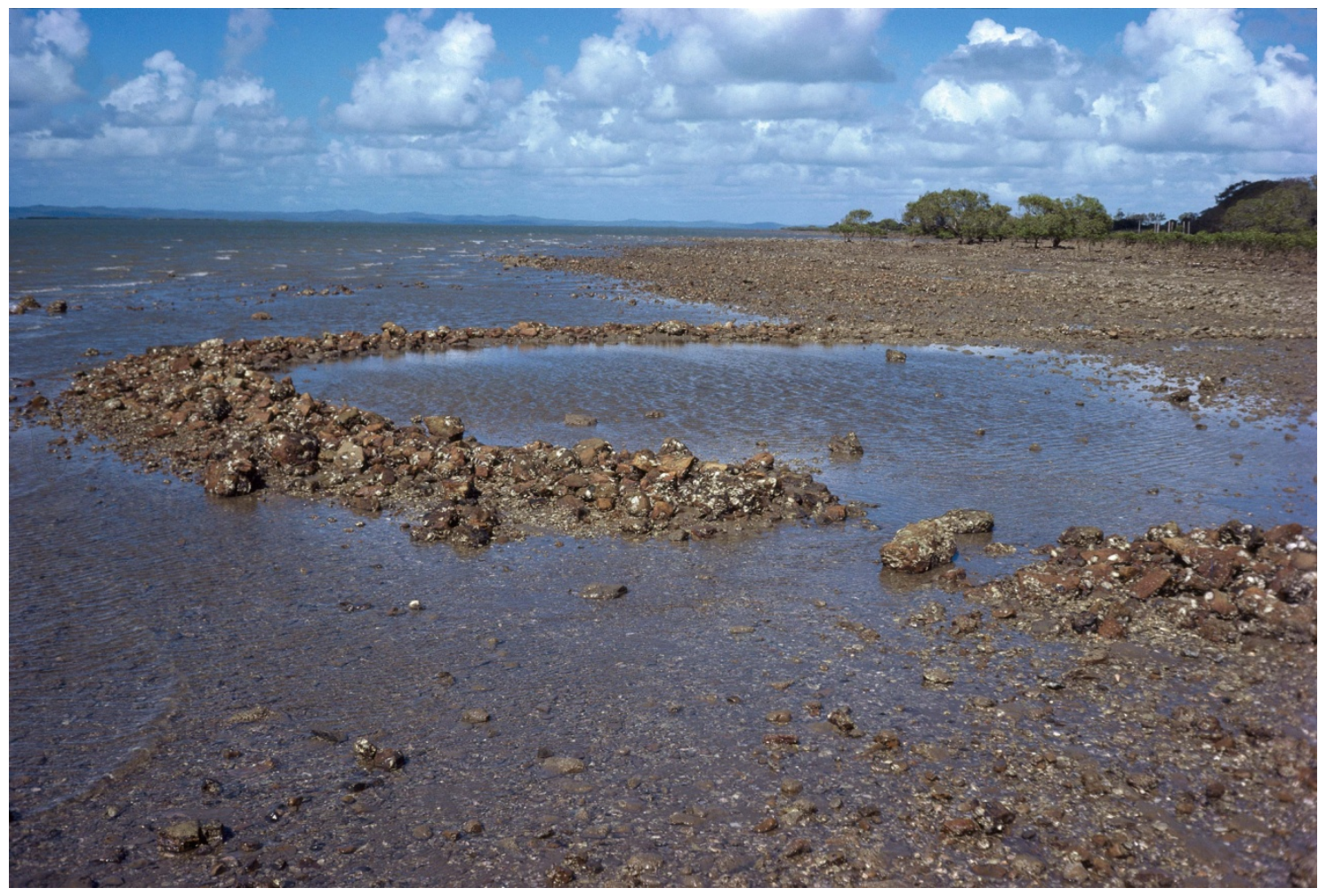

Figure 31. Fish trap KD:A13 at Booral, Great Sandy Staits (DERM ICHD Slide Collection).

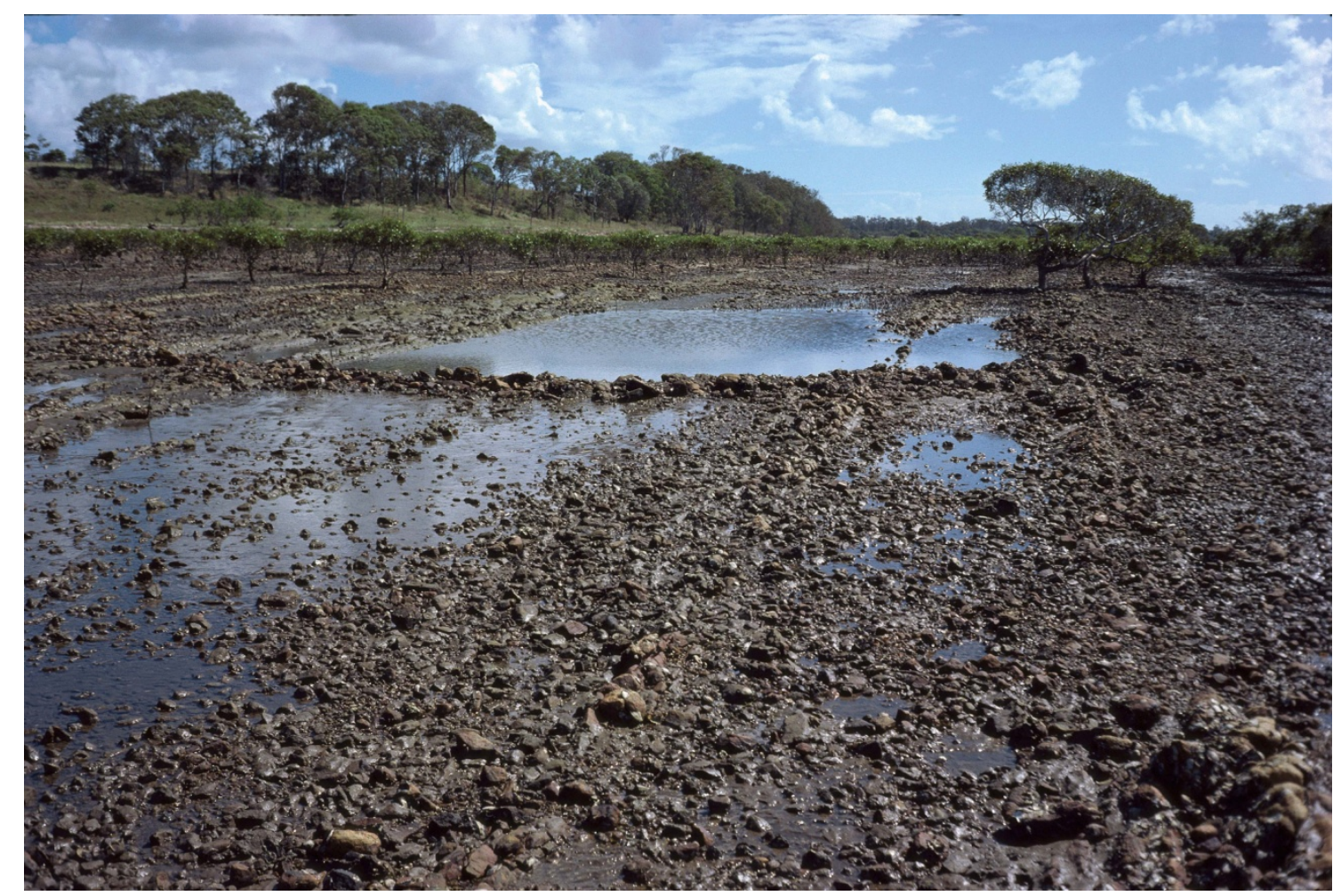

Figure 32. Fish trap KD:A14 at Booral, Great Sandy Staits (DERM ICHD Slide Collection). 
A semi-circular fish trap approximately 23.3m long and $26 \mathrm{~m}$ at its widest point is recorded at Point Vernon, Hervey Bay (KD:B45). The height of the wall is up to $0.5 \mathrm{~m}$ with two courses of flat slabs of stones. The wall consists of outer slabs with smaller rock infill. Observations by one of us (SU) note the presence of wooden pylons at the eastern margin suggest that this might be recent swimming enclosure rather than an ancient fish trap.

A fish trap is recorded on the southeastern shore of Lake Weyba (KC:E41). However its precise location is uncertain and available details of the site are poor. The rough sketch map of the site attached to the site card raises some doubts as to the builders of this trap. Photographs of the site held on file are not of assistance in further defining the nature of the site. A stone wall structure at Toorbul Point, near Bribie Island (LB:A37) (Figures 33-34), is widely regarded as an Aboriginal fish trap although its origins are uncertain. The structure is arc-shaped, with a single wall $73 \mathrm{~m}$ in length and $35 \mathrm{~m}$ across at its widest point with an average wall height of around $30 \mathrm{~cm}$. A number of aquatic species including various shellfish, crabs and prawns have been observed in association with the structure (Hogan et al. 1992:Table 3). There has been considerable debate as to whether the structure is an Aboriginal or South Sea Islander construction (Stockton 1975; Walters 1985), or a trap at all (Anonymous 1990). No plan of this site has been made but Connah and Jones (1983:Figure 2) have produced a very clear aerial photograph of the site. Cleary (letter to Alfredson 11 April 1995 in Alfredson 1995) identified the remains of a trap, presumably stone, at Pebble Beach in the Clontarf Bay area but insufficient details are provided to assess the site. A stone wall trap at Tallebudgera Creek (LA:A38) on the Gold Coast has been described as basalt boulders arranged to form an oval enclosure 100m long by $30 \mathrm{~m}$ wide. However, photographic evidence (Black 1995: Plates 60-61) suggests the arrangement had either eroded or was not designed for the purpose of harvesting fish.

In southern Queensland, traps and weirs made of organic materials appear to have been common in the early days of settlement. Petrie (1904:72-73), for example, described how fish were trapped in creeks along the southeast coast in the mid-nineteenth century:

The narrow and shallow parts of a creek would be blocked by stakes and bushes put across, and in this wall of bushes two or three openings would be left wide enough to permit of a blackfellow standing at each of them with his hand net ready (of course, nets for fish were much smaller than those for dugong). They would not go near, however, until the tide was on the turn, when they went and stood up to their necks in the water, ready to catch the fish. As a net began to fill the owner would close the mouth, and lifting up the pocket part, he would catch hold of each fish in turn, and, putting the head in his mouth, would give it a bite through the net to kill it. All the fish being killed, and so unable to escape, the man placed the net again in the opening, and stood ready for more, and so they went on till the tide had gone down, emptying their nets now and again, if they got too heavy, by throwing the fish to the bank.

Matthew Flinders also observed a number of organic fish traps near Clontarf Point (in Steele 1972:19).

\section{Summary}

Most traps and weirs on the Queensland coast are isolated structures and, in the case of traps, the majority have a single pen. Almost all exceptions to this trend are found north of Townsville. Multiple-pen traps occur at Hinchinbrook, Goold and Palm Island on the east coast. At Bayley Point, Point Parker and among the Wellesley Islands in the Gulf of Carpentaria multiple-pen fish traps are more common. In Torres Strait, and particularly on Moa, Erub, Mer, Mabuiag and Ugar they in some cases surround almost the entire coastline of the island. Of those traps south of Hinchinbrook Island, only those at Freshwater Point, Burnett Heads and Booral have two or more pens. While these are multiple-pen traps, with the exception of the Booral traps, they are not of the same order of magnitude as the traps north of Townsville. Nearly all the traps that are described have arc-shaped walls. The Scraggy Point trap has funnel-shaped pens, presumably meaning ' $\mathrm{V}$ '- or ' $U$ '-shaped. The exception to this regularity is the rectangular trap at Midge Point, although Barker (1988:10) argued it is not of Aboriginal construction. Some traps, for example, those at Moa, Bayley Point, Scraggy Point and Woody Island appear to have been built in stages since the traps have associated walls or features that were partly buried or permanently underwater at the time of recording. It therefore appears that new traps may have been built as the coastline changed, while older walls or features were abandoned. Traps are usually located at points and estuaries and not on open beaches. Traps and weirs on the leeward side of a point or in an estuary are sheltered from the brunt of wave and tidal action. Moreover, these are places that attract the greatest diversity (although not necessarily number) of aquatic fauna (see below).

Recorded organic weirs and traps are rare along the coast. However, it is likely that organic traps and weirs were more widespread but that natural processes have resulted in poor preservation. Organic traps were observed at Princess Charlotte Bay, Upstart Bay, among the Wellesley Islands, and Clontarf Point. These observations were made in the last century or the early part of this century and no coastal organic trap or weir has been recorded in the last 50 years.

There is some indication that Aboriginal people used nets to harvest fish from traps and weirs. Roth (1901), Jukes (1847), Flinders (1814) and Petrie (1904) referred to nets being used in conjunction with traps or weirs at Princess Charlotte Bay, Lefthand Branch Creek, Clontarf Point and the southeast coast, respectively. While net fishing was observed at traps, spearing or simply collecting marooned fish was also common. Thomson (1936) reported that poisoning, spearing, netting and line fishing were used by people of the Gulf. Robins et al. (1995:83, 1998) suggest that fish were speared in the Bayley Point trap and Tindale (1974:111) indicated the same for the Bentinck Island traps. Thompson (in Moore 1979) claimed people of Muralag harvested stranded fish by hand.

Finally, certain traps along the coast were built or maintained by non-Aboriginal people. As discussed above, Barker (1988) argued that the traps at Midge Point and, probably, Covering Creek were not of Aboriginal construction. McGarry (1987) suggested that first Aboriginal people, then South Sea Islanders of the 


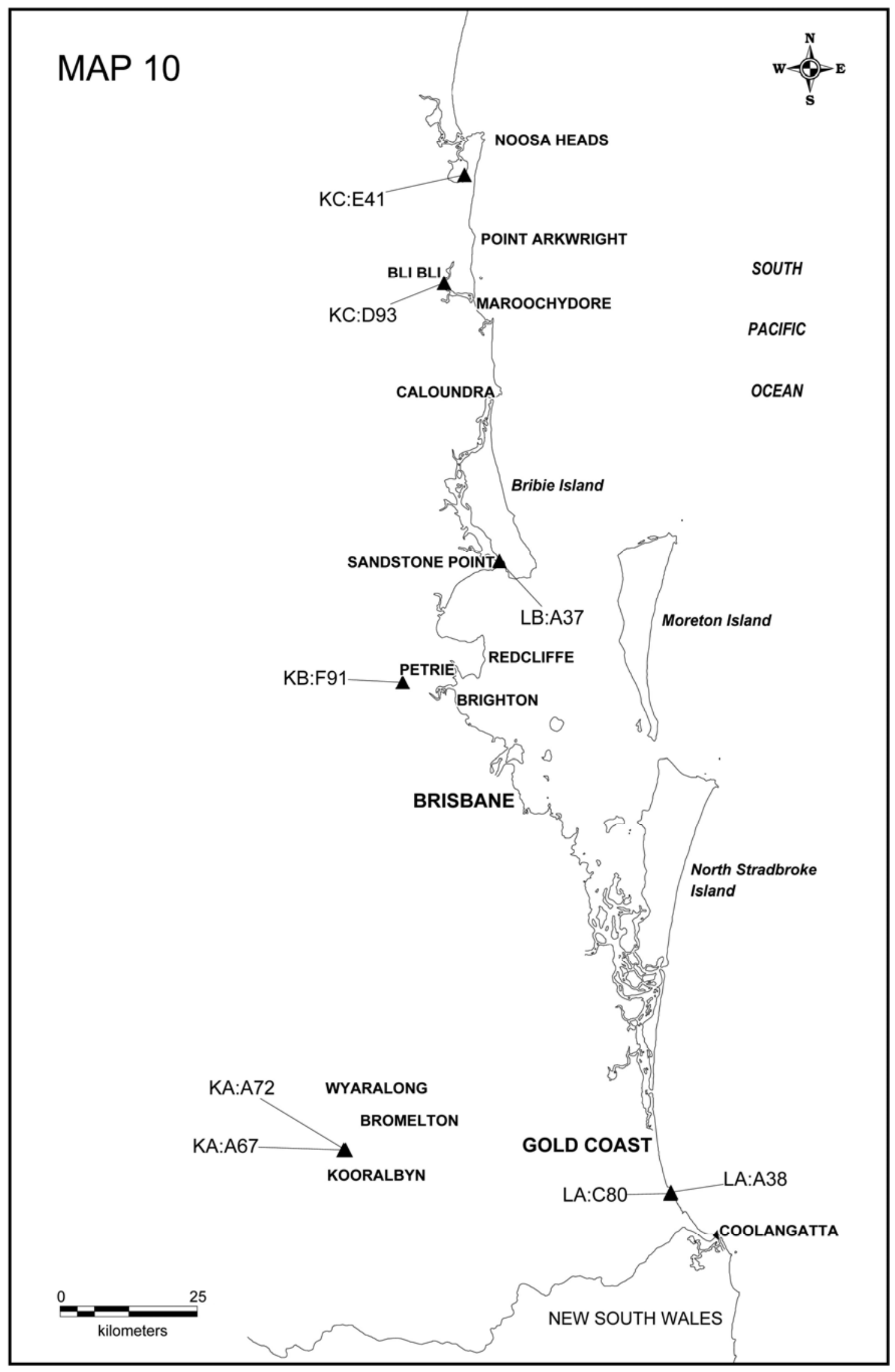

Figure 33. Fish traps registered on the ICHD, Great Sandy Straits, southeast Queensland. 


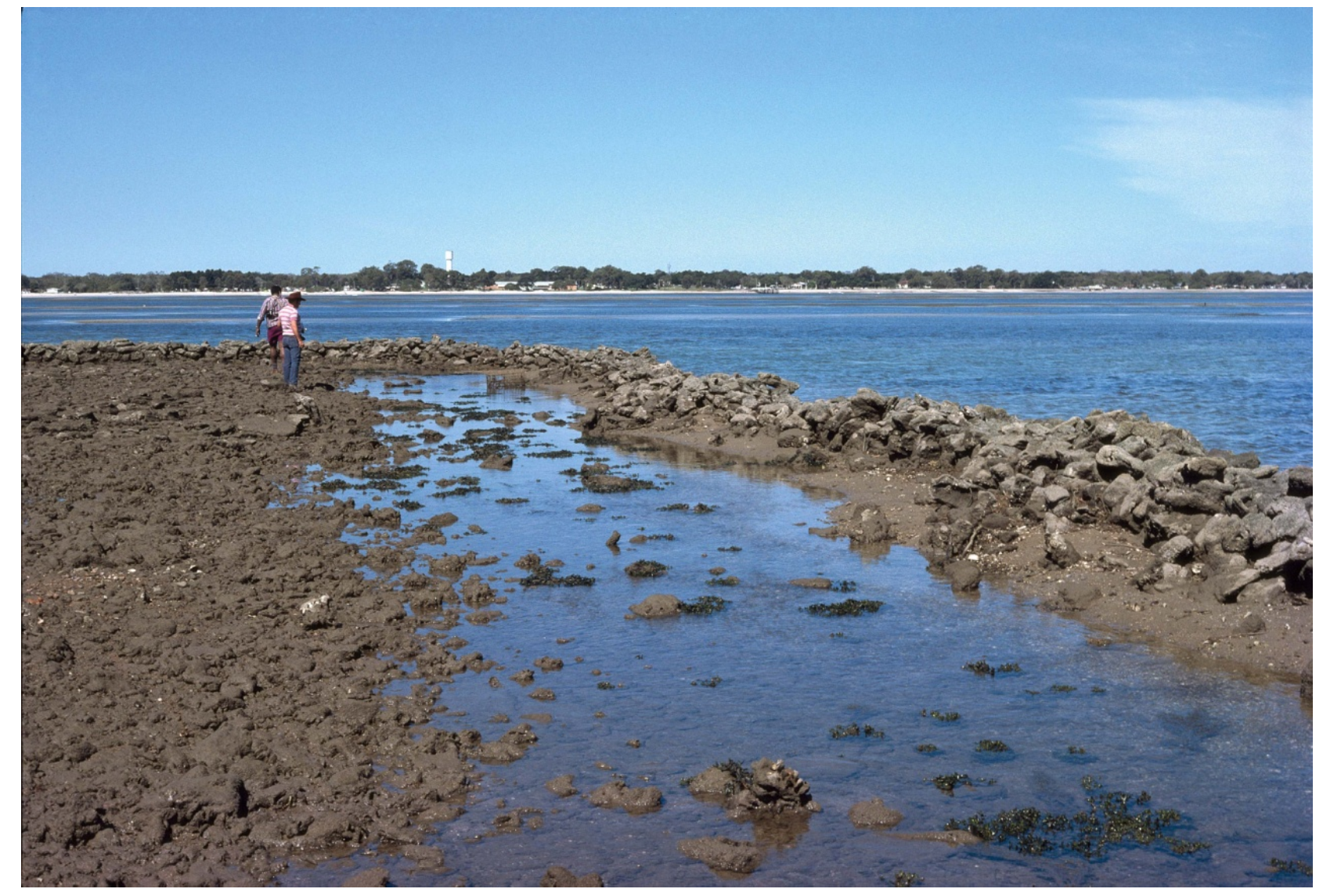

Figure 34. Fish trap LB:A37 at Toorbul Point, Great Sandy Staits (DERM ICHD Slide Collection).

Mackay region fished at the traps at McCready and Reliance Creeks and the weir at Gallagher Creek. The Reliance Creek trap was apparently used by Aboriginal people until the 1930s, and then by South Sea Islanders in the late 1940s and 1950s (McGarry 1987:59). South Sea Islanders also maintained the weir at Gallagher Creek (McGarry 1987:68). Likewise, Godwin (1992) was unable to say whether the Burnett Heads trap was an Aboriginal or South Sea Islander construction. There is genuine confusion with regards to the origins of the Toorbul Point trap with claims ranging from Aboriginal (Walters 1985), to possibly South Sea Islander (Stockton 1975), or European (Anonymous 1990).

\section{Types and Distribution of Traps and Weirs: Inland}

\section{Gulf of Carpentaria}

In the Gulf of Carpentaria Leichhardt passed two weirs, the first a 'fishing weir' in a creek near the Gilbert River (Leichhardt 1847:330) and the second in a mangrove creek near the Leichhardt River 'formed by many rows of dry sticks’ (Leichhardt 1847:347). Wright (1988:Table 8) also refers to Aboriginal people of the Leichhardt-Gilbert district as driving fish into organic traps made from boughs. Figure 35 illustrates the use of vegetation to form a trap in a tidal estuary on Mornington Island. Stone wall weirs in the 'North-West Central Districts' are described by Roth (1897:Plate XI, 1901:23) which had a break in the centre below which was a platform of woven grass through which water rushed leaving fish stranded on the platform. The platforms were built upon and surrounded by stones, and were covered by boughs. Instead of, or sometimes in addition to the platform, a net was fixed 32 | 2011 | Vol. 14 | q a r with two sticks on the lower side of the break to catch fish.

The Wik people of the Coen-Archer River region apparently built weirs and traps in small creeks and lagoons at the end of the dry season (McConnell 1930a:101), and decaying traps and weirs were located in lagoons (Ornyauwa) south of the Archer River (McConnell 1930b:198). They were used to catch fish as they swam upstream after the rain, and as they returned. Sutton (1994:39) notes that the Wik people of 'earlier times' made fish traps, probably from brush.

An organic weir on the Mitchell River was reported by Done (1929:68):

At the end of the wet season [fish] are caught by the people in a way peculiar to themselves. A weir of green bushes and grass is built across the stream, rising about 6 feet $[1.82 \mathrm{~m}]$ above the level of the water. This height is necessary because the fish will leap over obstacles in the path. A large hole is left in the centre of the barricade above the water, and the upper side of this hole is covered by a large basket arrangement. 


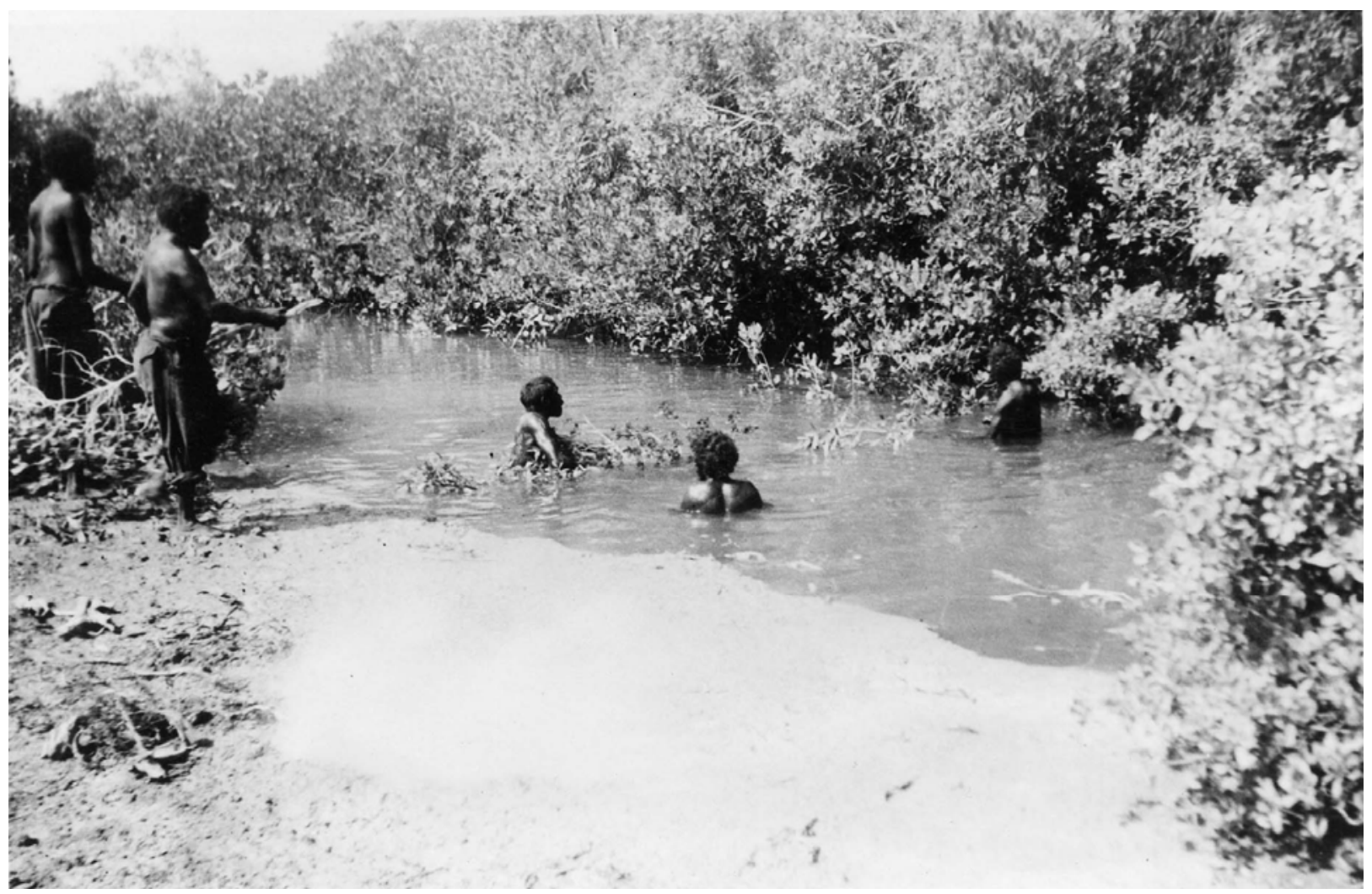

Figure 35. Use of vegetation to form a trap in a tidal estuary on Mornington Island (Photograph: F. McCarthy).

\section{Northeast Queensland}

An arc-shaped stone wall fish trap has been reported on the Mulgrave River (Bottoms 1990:11). Tenison-Woods (1882) reported crossing this river in 1882 noting that it was a great fishing station of the natives, perhaps because it was the only one where dams could be conveniently built. The Yidindji fish trap (FM:C08) is listed on the ICHD but no description is provided. Roth (1901:23) claimed baskets or cages were probably used to collect fish caught in traps at the Mulgrave as well as at the Russell and Barron Rivers. In 1885 Christie Palmerston noted on the Beatrice River, a tributary of the North Johnstone that:

\footnotetext{
aborigines have constructed a large fishery by damming one of the channels, and having a tiny floodgate in its centre, where they had fixed a long conically shaped basket in which they entrap the fish (in Savage 1989:170).
}

A stone wall weir $8 \mathrm{~m}$ long by $50 \mathrm{~cm}$ high (EL:A02) at the base of a waterfall on Glenlofty Creek, a tributary of the Burdekin River, has been reported by Brayshaw (1977:621). This weir was supposedly used to catch black bream (Acanthropagrus australis) at the end of the wet season when floodwaters were receding.

Flecker (1951) describes two stone wall fish traps at the Great Basalt Wall. In this location basalt rises in steplike formation to create rivulets that are full of fish during the wet season and traps were apparently built to exploit this seasonal abundance. The first trap consisted of several narrow races about $60 \mathrm{~cm}$ wide with walls approximately $60 \mathrm{~cm}$ high (FK:A23). A number of these races were complex and some also had associated deep holes which Flecker argued may have been used for holding fish. A trap was also found at a lake approximately $3 \mathrm{~km}$ west of Southwick that connects Lolworth and Fletcher Creeks. The trap sat in a $27.5 \mathrm{~m}$ wide channel that connected two lakes and the two walls converged to form a ' $\mathrm{V}$ ', which regulated the flow of fish between these lakes (FK:A24). Another site (FK:B27) is listed as being in the eastern section of the Great Basalt Wall 10km northwest of Lockwell but no further details are provided. FE:A10 is described as a dam formed from large boulders on Cheshire Station near Tambo.

Mulligan observed a weir being built, again of unspecified materials, while crossing the St George River in 1874:

[Aborigines] immediately abandoned a laborious piece of work they were engaged at, in making a wing-dam across a back bend or wing of the river in order to poison the water with branches and leaves to catch fish (in Jack 1921:434).

On the Normanby River in 1879 Jack (1921:488) described a 'native fishing station' where the mouth of a gully had been stopped by a fence of stakes and twisted branches. Jack assumed that barramundi had been caught in abundance because of 'the heaps of large scales lying about.'

Leichhardt (1847:188) came across an organic weir on the Suttor River, where it had broken down into a series of billabongs:

Recent camps of the natives were on each of them, and a beaten path led from one to the other. A weir made of sticks for catching fish crossed one of these holes. Bones of large fish, turtle shells, and heaps of muscles, were strewed round the fireplaces. 
Coyyan (1918) presents a particularly informative description of the capture of fish on inland waterways and rivers in the Tully area of north Queensland:

Fish play an important part with people. From the rivers great quantities are caught. Their method is to form small eddies with stones on the river rapids. Over the rapids at certain times the fish will go in shoals. Just as the day is beginning to dawn the fisherman and his mate will noislessly [sic] approach the lower end of the rapid. His device for throwing them out of the water is made from the lawyer vine, and is in appearance like two big fans joined together. The fisherman will walk in the water and throw the fish on to the land with his instrument, while his mate on land will secure the catch. This work must be done quietly as possible, and it is really wonderful how dexterous they are at the game. As soon as the sun begins to rise this style of fishing is abandoned.

I have known fisherman to catch over a hundredweight of fish by this method in a remarkably short space of time ... The fish are placed in leaves and then baked in hot ashes. When cooked the whole fish remains intact.

\section{Central Queensland}

In inland Queensland a stone wall weir is reported on the Burke River within 1km of Boulia (BG:A01) with a wall $30 \mathrm{~m}$ long and about $30 \mathrm{~cm}$ wide. On the Georgina River, Banfield (1909:53-54) described a large permanent organic weir:

\begin{abstract}
A tree had been felled across the stream so that the respective bank supported each end of the trunk. Straight stakes were driven firmly into the bed of the creek as closely together as possible, the heads resting against the horizontal tree trunk. This palisading formed the base of an embankment of packed grass and rubbish, sufficiently tight to raise the level of the stream about three feet [ $90 \mathrm{~cm}]$. In the middle of the embankment and about one foot $[30 \mathrm{~cm}]$ below water level a hole about one foot square had been cut. A platform about ten feet [3m] long by three feet wide $[90 \mathrm{~cm}]$, having a fall of about one foot and formed of a number of straight saplings laid parallel with the stream, and supported by a couple of transverse bearers on four stout forked sticks received the escape from the sluice. At the lower end of the platform was a rough weir of twisted grass that was continued up each side for about half its length. Water passed with little hindrance through the platform, while jew-fish, yellow-tail and bream were retained in considerable numbers.
\end{abstract}

\section{South Queensland}

McKinlay (186?:69) observed a 'native fishing weir' on one of the Diamantina River channels in 1862. In 1847, Kennedy observed Aboriginal people camped at a 'rocky ford' on the Barcoo River (Beale 1983:133), but it is uncertain whether this was a natural or artificial feature.

At Gray's Creek, near the Queensland border, William Wills (1863:195) described an organic trap in 1861:

At the upper end of the creek we found in its bed what appeared to be an arrangement for catching fish: it consisted of a small oval mud paddock about twelve feet [3.6m] by eight feet $[2.4 \mathrm{~m}]$, the sides of which were about nine inches $[22.8 \mathrm{~cm}]$ above the bottom of the hole, and the top of the fence covered with long grass, so arranged that the ends of the blades overhung scantily by several inches the sides of the hole.

Dargin (1976:22) identified similar mud pens in use in the Darling-Barwon district during times of low water.

In 1845, Sturt came upon a lake in the Cooper Creek district where 'a line of poles ran across it' (Sturt 1849:36). The lake had 'native paths' and huts associated with it but it is unclear whether the line of poles was a device for catching birds or fish. Stone wall fish traps have been recorded in Cooper Creek, near Nappamerrie Station which were just covered by water at the time of recording (CB:A10). A stone wall weir (DC:A08) was observed on Thylungra Homestead east of Kyabra Creek, a tributary of Cooper Creek and a stone artefact scatter was found nearby.

Traps were observed on the Bulloo River in 1861, where:

at the northern termination of the water-hole, where the creek branched with insignificant channels, numbers of ingeniously-constructed fishing dams showed that the natives derived a considerable sustenance from its waters (Wright 1862:518).

In the Channel Country trapping was important and fish were penned for future use:

[The Aborigines] went to a great deal of trouble to trap game and fish. In the streams, and watercourses especially in the deeper permanent holes he constructed traps; some were huge affairs built of stone or stiffly staked woven reeds resembling small pens. In these pens were mustered fish by the hundreds in good seasons, and hence they were kept alive - and fat - until required for a feast (Duncan-Kemp 1968:275).

Two stone wall weirs have been recorded on the Bulloo River. No details of the first trap (EC:A15) are provided other than noting an association with the Bunthamarra people. The second trap (EB:A01), known as the Piastre trap, was observed in 1972 on Manu Manu Creek, one of the branches of the Bulloo south of Quilpie (Rowlands and Rowlands 1972:10) (Figure 36). This trap was situated on a rocky bar near two permanent billabongs and consisted of four banks of stones $70-80 \mathrm{~cm}$ high. The first two banks extended from either side of the creek to within $1 \mathrm{~m}$ of each other, while the other banks were on the upstream side of the $1 \mathrm{~m}$ gap and curved away, forming two large enclosures. The banks thus acted to channel fish into the $1 \mathrm{~m}$ gap where, presumably, nets or cages were set. The trap was in good condition in 1972 but had been degraded by successive floods.

The Piastre trap (EB:A01) has recently been recorded in detail by Richter et al. (2006). They note the presence of eight other sites in the area including seven artefact scatters/camp sites and a stone arrangement. The fish trap is on Manu Manu Creek approximately $7 \mathrm{~km}$ upstream of the junction with the Bulloo River.

In all, about $150 \mathrm{~m}$ of stone walls were identified and mapped (Figure 37). They consisted of arcs, V-shapes and a circle with stone walls ranging from $20 \mathrm{~cm}$ to $70 \mathrm{~cm}$ in height. A downstream main wall $60 \mathrm{~m}$ long crosses the creek in an arc at right angles running almost from bankto-bank. Two further arcs, one on the north side of the 


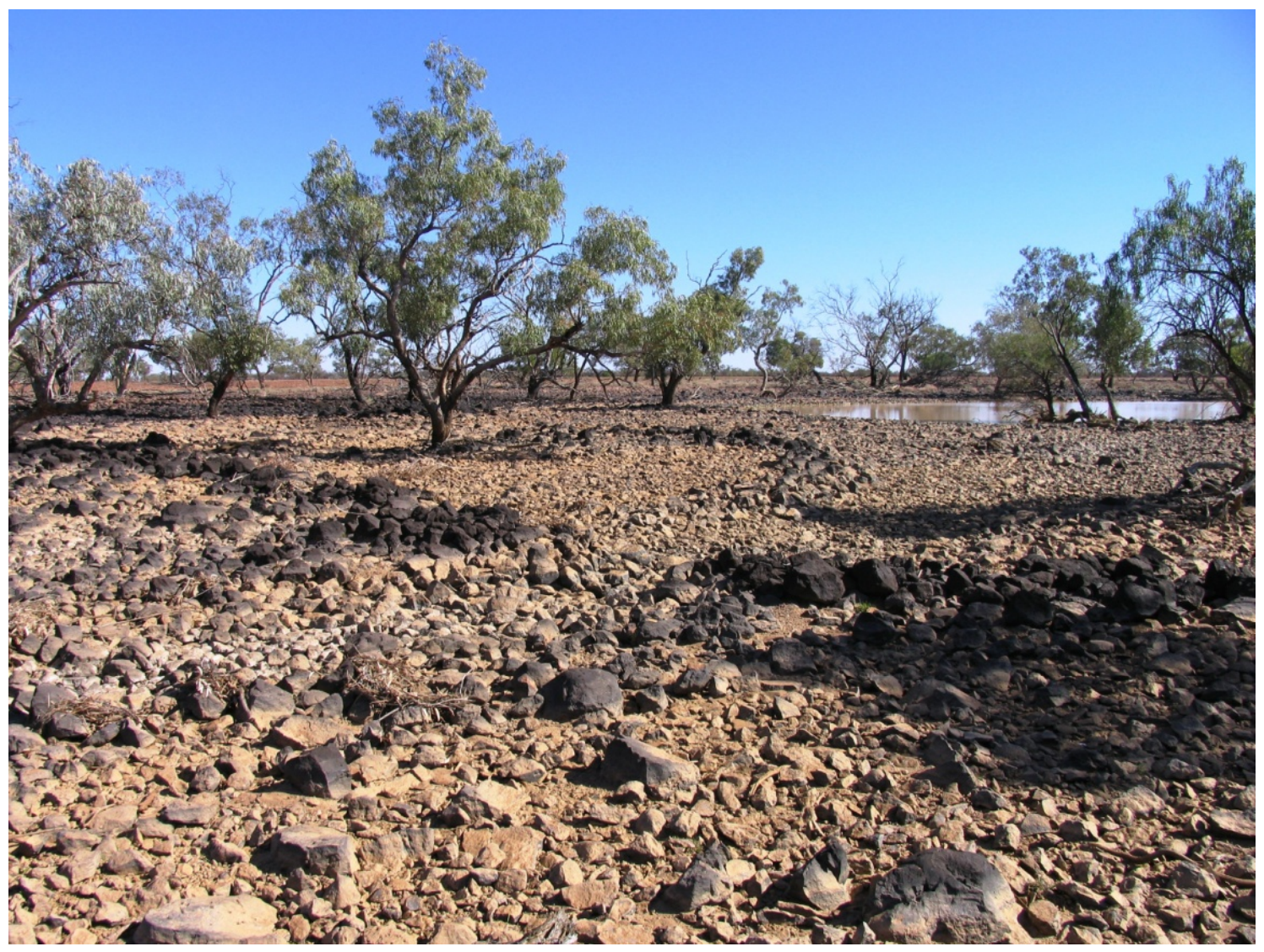

Figure 36. Fish trap EB:A01 (the Piastre trap) on Manu Manu Creek, south of Quilpie (DERM ICHD Slide Collection).

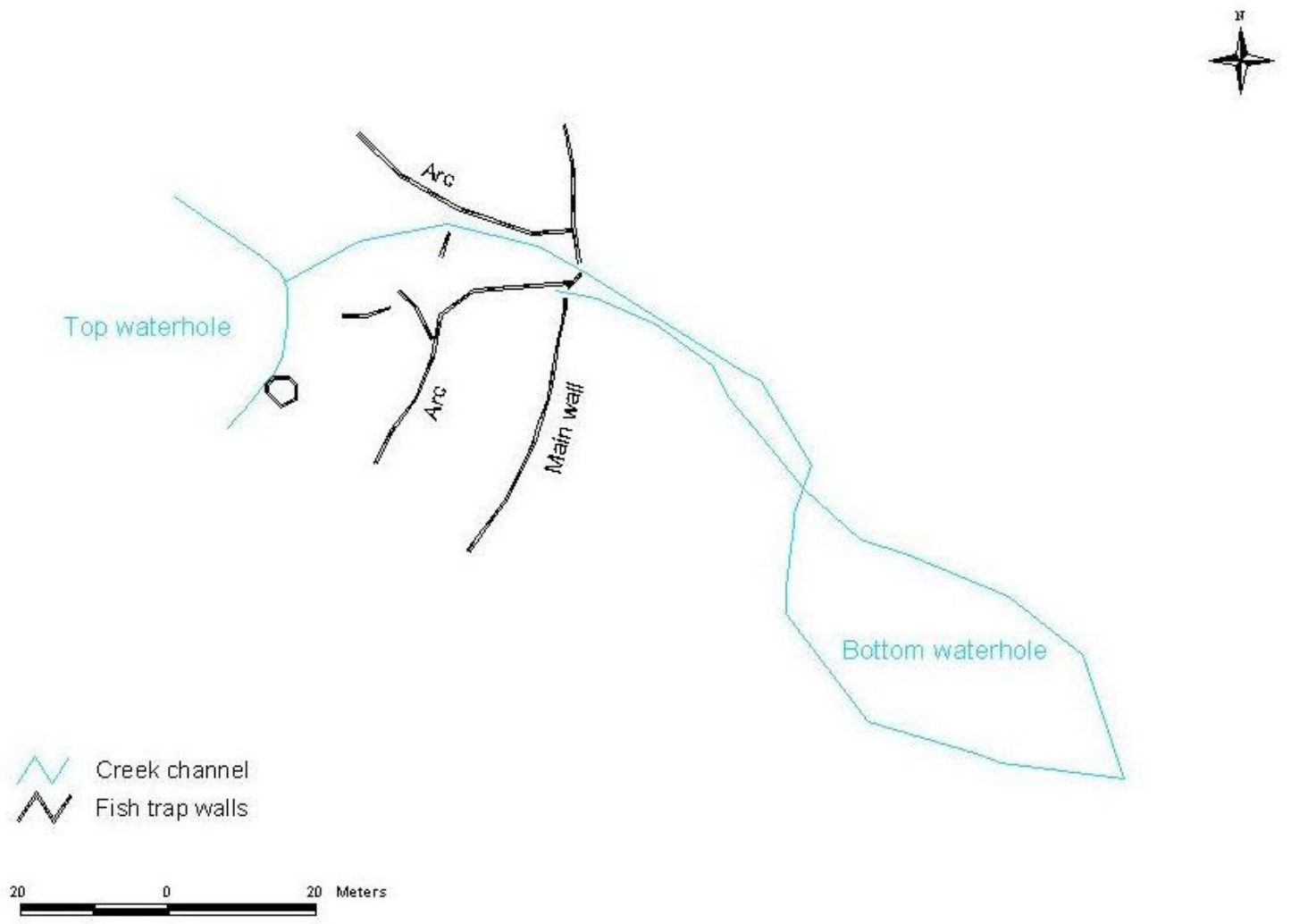

Figure 37. Plan of fish trap EB:A01 (the Piastre trap) on Manu Manu Creek, south of Quilpie (DERM ICHD Slide Collection). 
creek measuring 30m and a southern one 38m long meet up with the main wall in the centre of the creek. These two walls provide a V-shape to force fish through the centre of the main wall. The main walls provide a v-shape to force fish through the centre of the main wall. The main wall has two openings. Either side of these openings are piles of rocks which according to Richter et al. (2006) may have been used to either close the trap when being used or block the southern channel after water and fish have entered a holding pond between the southern $\mathrm{V}$ shaped arc and the main wall through back flow from the main channel. A small stone circle, about $2.5 \mathrm{~m}$ in diameter, was also noted on the edge of the upper pool and may have operated as a trap.

Richter et al. (2006) found that some damage had occurred at the site from its first recording in 1972. This is generally attributed to flood damage which has moved stones and decreased the height of the stone walls.

In August 2008 the then Department of Natural Resources and Water, the Mardigan Aboriginal Traditional Owners and the landowners of Piastre Station signed off on a Cultural Heritage Management Plan to manage an area covering 20 hectares which should ensure the ongoing management of this site.

An organic weir (HC:A42) was recorded at Snake Creek, southeast of Roma where it was noted the weir was associated with a group of axe-grinding grooves. Richardson (1983) described two stone wall fish traps between Cunnamulla and St George. The first at Balonne River (HB:A02) was destroyed in 1949 to make a European weir. The second at Nebine Creek (FA:A12) had been damaged in the early 1980s for similar purposes. Mitchell (1848:103) observed 'a native fishing fence' while crossing the Narran River in 1846, and noted that access to this weir was gained by means of 'a beaten track'. A site in the Chinchilla area (JC:A93) is listed as a weir but it is difficult to determine the nature of the site from the description.

Petrie (1904:74) described the capture of freshwater eels in Queensland's southeast:

fresh water eels were gradually caught in times of drought ... At other times [Aborigines] would dam a small portion of water with mud banks, leaving openings in each wall, and then, when the eels (or fish) went through, the holes would be blocked and small hand nets used to scoop up the fish; or they were speared.

Petrie (1904:73) specifically mentioned traps at North Pine River:

the portion of the North Pine River near where the railway bridge now crosses was known by that name [mandin], for it was a great place for fish, and the blacks used to have a breakwater of bushes built there.

Oxley (in Steele 1972:107) also observed a weir on Pine River in 1823. Flinders noted organic traps at Clontarf Point (see above).

\section{Summary}

A dichotomy occurs in the nature of traps and weirs east and west of the Great Dividing Range. Weirs are reported more often than traps east of the Great Dividing Range, while traps are more commonly reported west of the range, particularly in southwest Queensland. There are 36 | 2011 | Vol. 14 | q a r some traps east of the Great Dividing Range in North Queensland (Barron, Mulgrave, Russell and Tully Rivers) but these are matched in number by weirs. This dichotomy does not apply to building materials, where there is a similar proportion of stone and organic traps on either side of the Great Dividing Range. Some traps and weirs may have been built to capture food that was in temporary abundance. For example, most waterways of the southwest only flow at certain times of the year and otherwise become disconnected waterholes. Fish generally spawn in those periods when water flow is at a maximum. It would therefore be reasonable to assume that some traps and weirs were built in times when fish were most active and conditions for catching them at their best. Baskets, cages and platforms seem to have been used to collect aquatic fauna, although spearing or collecting marooned fish was also possible. Baskets or cages were observed at many traps in north Queensland while platforms were observed in central Queensland and the Gulf. Nets were used in southeast Queensland and sometimes in the Gulf, instead of platforms. In the case of southeast Queensland, it is unclear how far inland nets were used, given Petrie's (1904) silence on the precise distribution of fishing techniques.

\section{Interpretation and Discussion}

\section{Aboriginal, Non-Aboriginal or Natural Construction?}

Aboriginal and Torres Strait Islander people may have built traps and weirs in Australia since at least the early Holocene (Head 1989) and perhaps earlier. At Lake Condah in Victoria, for example, Head (1989) notes that some traps could have been operable from at least 8000 years ago, but were perhaps only associated with continuous occupation in the last 2000 years. Attempts to directly date the antiquity of the traps have met with limited success, with hints of a mid-Holocene age (McNiven et al. 2009). However, since 1788 no less than four groups have built or used traps and weirs in Queensland including Aboriginal people, Torres Strait Islanders, South Sea Islanders, and other non-Aboriginal peoples (including Europeans). A fish trap or weir has a limited number of potential forms and none of these could be considered to be characteristic of a single group. Aboriginal, Torres Strait Islander and South Sea Islander people as well as non-Aboriginal people all built ' $\mathrm{V}$ '-or arc-shaped traps (Codrington 1891:318; Hornell 1950:153-157; Jenkins 1974:7). The exception is that Europeans occasionally made their traps in a square shape (Barker 1988; Colhoun and Piper 1982; Godwin 1988; Hornell 1950:85; McGarry 1987:v), while no known Aboriginal or Torres Strait Islander traps were made in this shape. Nonetheless, there is no evidence that Europeans exclusively made square traps.

The problem of classification is compounded by the many instances in which different groups used the same trap or weir over time. For example, South Sea Islanders had knowledge of traps and weirs or had fishing techniques taught to them by Aboriginal or Torres Strait Islanders (Gistitin 1995:19; Mercer 1995:30,179). As a consequence, South Sea Islanders occasionally caught fish in abandoned Aboriginal traps, built their own traps and remodelled or maintained Aboriginal traps (Clive Moore, Department of History, University of Queensland, pers. comm., 1996).

Indigenous Fish Traps and Weirs of Queensland 
The location of a trap or weir may be identified from historical documents. For example, Bird (1987:50) was able to identify the location of a weir, which has now disappeared, as being at Lefthand Branch Creek in Upstart Bay (see above). Oral history may also assist in identifying traps and weirs. For example, Britnell (1991:56-57), through discussions with the local Aboriginal community, was able to identify and date a stone wall trap at Nob Point, Cape Bedford. He reported that the Aboriginal residents of the mission built the trap after World War II, but had not used traps and weirs previously. Unfortunately, historical documents and oral histories dealing with traps and weirs are not common. Neither historical documents, oral histories nor dating of a trap or weir is helpful in identifying those people who may have actually used a structure.

As discussed above it is possible for a trap or weir to have been built and used by one group and subsequently maintained and used by another. The stone structure at Toorbul Point (LB:A37) sits in the intertidal zone, has a low stone wall in the shape of an arc and fits the general description of an Aboriginal fish trap. However, $\mathrm{Mr}$ James Clark, whose family owns the land at Toorbul Point, claimed his grandfather directed South Sea Islander labourers to build the structure for the purpose of farming oysters (Anonymous 1990). Walters (1985:44-45) has argued that the Toorbul Point structure is an Aboriginal trap by virtue of it having been used by an Aborigine (Ms Ann Birt) to capture fish. The abundance of nearby middens containing fish bone might also lend credence to this view (see below).

A further problem is that other arrangements of stone are occasionally mistaken for fish traps (e.g. McNiven 2003; Walshe 1996; Woodford 1996). For example, it is likely that the fish trap identified at Tallebudgera Creek (LA:A38) served some other purpose. Photographs of the 'trap’ (Black 1995:Plates 60,61) suggest it either was not designed for the purpose of capturing aquatic resources or has greatly eroded. The 'trap' at Sunset Bay (HH:A16) and the weirs at Pioneer River are also unlikely to have been built for the purposes of trapping. The second-hand description of the Sunset Bay site, its reported location and photographs of the structure make it unlikely that this is a trap (McGarry 1987:Plates 9,10). Close analysis of the photographs (McGarry 1987:Plates 7,8) leads to a similar conclusion for at least one of the Pioneer River weirs. The stones appear to be natural deposits. There is no apparent structure or arrangement of stones and there is no size sorting of stones that might be expected in the case of a stone trap or weir.

The problems of identifying the function and builders of stone arrangements are many and varied and have not been addressed in detail by researchers. A partial solution to this problem is to set in place a convention for recording traps and weirs. This will avoid unnecessary confusion by establishing the defining traits of traps and weirs. A recording convention will also result in uniformity of collected data and allow better comparison between sites. Suggested criteria for recording traps and weirs are set out in Table 2.

\section{The Origin of Traps and Weirs}

The apparently simple structure of traps and weirs suggests that they could have been locally invented on a number of occasions. However, the widespread distribution of traps and weirs among fishing communities of the world (Connaway 2007; Hornell 1950:136,153-157; Jenkins 1974) might also imply the possibility of a common origin. McCarthy (1940), for example, argued that traps and weirs entered Australia via Torres Strait with a number of other imports in the Holocene. McConnell (1930a:97-100) noted that the Wik people of Cape York showed signs of prolonged contact with Papuan people and claimed that a legendary group of people called the pulwaiya had taught the Wik how to build and use traps (McConnell 1930b:187).

Throughout the Wellesley Islands it is generally believed that traps (Lardil: derndernym; Kaiadilt: ngurruwarra) were built by mythic ancestors. The North Wellesley Islanders believe the first Lardil people Maarnbil, Jirnjirn and Diwaldiwal - who brought culture and language to Mornington Island, shaped their traps. The Kaiadilt view is that the original construction of the many traps in the South Wellesleys is attributed to Bujuku (Black Crane) and Kaarrku (Seagull), but that older people also recall the contributions of human labour in building and maintaining the traps. In the vicinity of Bayley Point and Point Parker on the mainland coast, the rocks comprising fish traps are believed to be the flesh of the Bijarrba (Dugong) Dreaming ancestor (Memmott and Trigger 1998:112-114; see also Memmott et al. 2008).

The issue of origins is complex and remains to be addressed by further research. Some archaeologists support the view that most items of Aboriginal material culture were local innovations, while others hold that new implements and technology were brought into Australia by diffusion of ideas or migrations of people (e.g. Flood 1988:196). O'Connor and Veth (2000:128-129) see the construction of fish traps as a probable late Holocene innovation since reef systems that support them were probably not sufficiently developed in most areas prior to the late Holocene. They note that these issues are important but elude us because of the difficulty of dating fish traps. In some areas traps and weirs could have been a local innovation or an import, or both. The dating of traps and weirs may resolve some issues relating to this problem (see below).

\section{Distribution of Traps and Weirs}

There were 179 traps and weirs recorded on the Queensland Indigenous Cultural Heritage Database as of April 2010 (Appendix A). Of the 179 reported traps and weirs, 159 sites were located on the coast and 20 inland. Figure 1 and associated insets show their distribution throughout Queensland. They were widely distributed across Queensland during the frontier period (e.g. Roth 1901:23), and presumably before the arrival of nonIndigenous people. Traps and weirs occurred in some parts of the State more often than they did others, or at least have been reported more often in some areas.

Coastal traps and weirs are rare south of Mackay, which is in marked contrast to the relative abundance of traps and weirs to the north between Mackay and Cairns. A possible explanation for this is that Mackay marks the southern limit of protected, low energy coastlines. The Capricorn Channel is a break in the Barrier Reef southeast of Mackay that focuses the tide-wave between latitudes $21^{\circ}$ to $23^{\circ} \mathrm{S}$ into Broad Sound creating spring tides of 6- 
Table 2. Identification checklist for fish traps and weirs.

\section{Identification}

A trap is any structure having a length and shape that creates a pen or comprising at least two walls joined at a right angle. It is an artificial object.

A weir is a wall that seals natural conduits of water such as streams, creeks, coves and so forth. The wall may include natural features.

\section{General Guidelines}

1. Record the location of the trap or weir using a GPS or on a map or, if a map is not on hand, take care to record how to get to the site so that others can pinpoint it on a map.

2. Report the find to the Department of Environment and Resource Management, Cultural Heritage Coordination Unit. People often neglect to report a find because they think it is unimportant or somebody may have already reported it. Even if the authorities do know of the site, it is valuable for them to know its present condition.

3. Try to photograph or at least draw a picture of the trap/weir. The more images the Department of Environment and Resource Management, Cultural Heritage Coordination Unit has of a trap or weir available the more useful the information become to future researchers and Indigenous communities.

4. Record as much information as you can; often it is the details left out of a file or report that are important.

5. Any measurement taken of a trap should be explained - it is important to record what the measurement represents, how it was taken and even where it was taken.

\section{Checklist 1: Traps}

1. Describe trap. Is the trap an arc, square, 'V', maze, or other shape? Is it a single trap or part of a complex? Is it made of stone or organic materials?

2. Photograph or draw the trap. Try to get as many images as possible, including an overall view of the structure. Draw attention to any unusual features. If possible, use a scale (something standard size like a ruler, pen, clipboard etc).

3. Measure wall length. If wall is unbroken, nominate one end as a datum and measure to other end. If wall is broken, nominate a datum and measure remnant walls as well as the intervening gaps.

4. Measure apex. The apex of a trap is the longest line from the trap's outer termination to intersect a line connecting the trap's landward edges. That is:

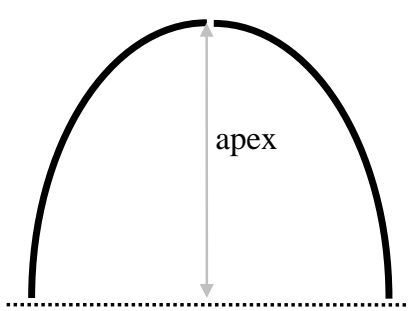

5. Measure width. Measuring the trap’s maximum width is generally sufficient.

6. Measure wall height. The wall should be measured for its maximum, minimum and average heights. It does not matter what dimensions you measure (i.e. top of wall to bottom of wall, or top of wall to ground) as long as they are clearly identified and used for each measurement. Count the number of stone courses.

7. Calculate area of enclosure. This is a simple calculation of area namely, length $\mathrm{x}$ width.

8. Describe the wall. Of what is the wall made? Does it have any unusual features? Does the wall have shellfish colonies growing on it?

9. Describe the pen. Is the floor sandy, rocky, vegetated? Does it have any unusual features? If there is more than one pen, are they the same depth?

10. Describe the context. Is the trap on a mudflat, open beach, tidal inlet, estuary, floodplain? Is there any other archaeological material in the immediate area?

11. Describe the condition. Does the trap appear run-down? Are there any agents contributing to its degradation (e.g. animals, erosion, human interference etc)?

12. Assess potential impact. Is the trap in a location where people will visit it on a regular basis? Is the trap likely to be affected by human activity? 
Table 2. Identification checklist for fish traps and weirs.

Checklist 2: Weirs
1. Describe the weir. Is it a single wall? Is it organic or stone?
2. Photograph or draw the weir. Try to get as many images as possible, including an overall view of the
structure. Draw attention to any unusual features. If possible, use a scale (something standard size like a
ruler, pen, clipboard etc).
3. Measure wall length. Nominate a datum and measure from this point. If the wall is broken, measure the
length of the remnant wall and the intervening gaps.
4. Measure wall height. The wall should be measured for its maximum, minimum and average heights. As with
traps, a standard should be set and used for each measurement. Count the number of stone courses.
5. Describe the wall. Of what is the wall made? Does it have any unusual features? Does the wall have shellfish
growing on it?
6. Describe the context. Is it in a stream, creek, inlet? Is it near any other features, like an estuary, river,
waterfall? Is there any other archaeological material in the immediate area?
7. Describe the condition. Is the weir in a state of disrepair? Are there agents of disrepair still affecting the
weir?
8. Assess potential impact. Is the weir in a location visited by people on a regular basis? Will the activities of
people affect the weir?

9m (Pickard et al. 1977:21). Such a range in tides would damage all but the most protected of traps in a relatively short period of time. Nevertheless, the general absence of traps and weirs continues south of $23^{\circ} \mathrm{S}$, which means that high tidal range is not the only factor contributing to the absence of traps and weirs. The Swain Reef terminates at $22^{\circ} 5^{\prime} \mathrm{S}$ creating surf beaches south of this point. As a consequence few locations south of $22^{\circ} 5$ 'S have the same protection as the coast north of $21^{\circ} \mathrm{S}$, a situation that would militate against the placing of traps. An added pressure on traps and weirs south of $21^{\circ} \mathrm{S}$ has been sustained and widespread development of the region. The single major concentration of traps and weirs south of $21^{\circ} \mathrm{S}$ is in the Great Sandy Strait at Booral, which is protected from extreme surf conditions by Fraser Island. The intensive use of the southeast corner of the State since 1824 may have destroyed some other traps and weirs in the region. For example, stone may have been removed from traps and weirs to be used for other purposes as it has from similar structures around Australia (e.g. Gill 1970:30; Massola 1969:78-79; McGarry 1987:61,67; Richardson 1983:39). Nevertheless, development has concentrated in specific areas and has not been uniform along the coast. Therefore development can not be the only reason for the apparent absence of traps and weirs in the State's southeast corner. It may be that traps and weirs were infrequently constructed in this part of the State.

Fish traps in the Gulf of Carpentaria are located among the Wellesley Islands group and on the adjacent mainland at Point Parker and Bayley Point. There is an apparent absence of traps and weirs elsewhere in the Gulf although weirs have been observed in a few rivers. Their apparent absence may be due in part to a lack of survey in these other areas, although it is unlikely sites of such dimensions as those described above would have been overlooked. Other explanations must therefore be considered. Across the Gulf region Memmott and Trigger
(1998:114) estimate a total of 334 individual traps (located at 108 sites) on the islands and along the mainland coast. In general most of the smaller islands have a relatively dense distribution of traps and sites. Bentinck Island is enormously rich in this respect with an average of one site every $0.9 \mathrm{~km}$, and a figure of one trap per $0.4 \mathrm{~km}$. In contrast on Mornington Island there is one site for roughly every $20 \mathrm{~km}$ of coastline. The range in tides found throughout the Gulf might account for the absence of traps and weirs on open sections of the coast. Tides range from $2.4 \mathrm{~m}$ at Weipa to $3.2 \mathrm{~m}$ at Karumba (Rhodes 1980:33) and given the magnitude of these tides it is not surprising that traps and weirs might only survive in sheltered positions like Point Bayley or Point Parker, and the leeward side of the islands. Nevertheless, there are many other protected areas in the Gulf region that do not appear to have an associated trap or weir. Alternatively, Memmott et al. (2008) have suggested that differences in fish trap distribution might be related to a greater dependence on this technology amongst Kaiadilt on the south Wellesley Islands. The southern coast of the Gulf is characterised by a narrow mangrove fringe and extremely wide, arid salt pans (Munro 1972:14), while the remainder is sandy beach. Boulders of ferruginous laterite can be found (Robins et al. 1995:8, 1998), but in general stone for making traps is limited. This is consistent with the observations of Leichhardt (1847) and Thomson (1936) that weirs in this area were also made of wood and that many other items of material culture were made of organic materials. Therefore, it is possible that traps and weirs were more widespread in the Gulf but, being organic, have disappeared.

There does not appear to be any obvious pattern to the distribution of traps and weirs in inland Queensland. Traps and weirs are found throughout inland Queensland with the exception of the Mitchell Grass Downs, where they are conspicuously absent. Traps and weirs do not appear inland with the same frequency as they do on the coast. It is unclear why this would be the case although it 
is possible that traps and weirs of inland Queensland were mostly made of organic materials and therefore have since degraded. In some areas other fishing techniques may have been important but have left no structural evidence. It is also likely that aquatic fauna of inland waterways do not have the wide distribution or relative abundance that they do on the coast and therefore, traps and weirs were localised. This explanation would apply to the seasonal waterways in the State's southwest but is less useful in explaining the relatively few traps and weirs reported on the perennial waterways of the Gulf or east of the Great Dividing Range. Here, however, regular seasonal flooding may have destroyed all but major traps and weirs. Social factors also played an important role in the placement of traps and weirs and these are discussed below.

\section{The Function of Traps and Weirs}

It is generally argued that traps and weirs are productive, labour intensive, efficient or reliable and in some cases all of the above. Some of these assumptions may be correct, others incorrect or exaggerated, while each is in need of closer study.

It is widely assumed that traps and weirs increase a group’s food supply (Balme 1983:31; Barker 1992b:53; Campbell 1978:129; Coleman 1982:9; Harris 1977:458459; Sutton 1986:12; Trigger 1987:79-80) and at extensive traps like those at Bayley Point, Point Parker or Scraggy Point this was probably the case. However, the majority of traps found in Queensland are small, having a single- or, occasionally, double-pen, while weirs are a single wall and these smaller devices may not have increased a group's food supply in any significant way. It has been assumed that trapping results in the growth of fish production (Campbell 1978; Coleman 1982; Walters 1985). However, while it is the case that production goes up a step, it is not the case that it continues to increase. On the other hand, trapping is a technique that raises the probability of a return but does not guarantee it. This is apparent from a study of returns from fish traps in Western Australia (Smith 1983). In this study it was demonstrated that while fish traps increased potential harvest they did not increase production per se. It also implies that people were looking for certainty of return or variety to their diet, or both. It further demonstrated that trapping was just one way among many of getting food and that trapping is only effective at times of the year when fish are available to be caught.

There is also no reason to assume that traps and weirs require high levels of organised labour. Building or maintaining a trap or weir is not necessarily labour intensive (Avery 1976:109; Coutts et al. 1978:33; Smith 1983:32; Stockton 1982:112). Traps have sometimes been dismantled when they are to go unused for a time to prevent the unnecessary waste of food (Smith 1983:31). The efficiency and reliability of a trap or weir is directly related to its condition and one that falls into disrepair is neither efficient nor reliable. Trapping requires that labour is spent on maintenance but this does not have to be continuous. For example, Bird et al. (1995:7) and Altman (1983:63) both described traps and weirs that were maintained on a yearly basis.

It would seem that relying exclusively on a trap or weir to capture fish would not significantly improve a return. This is a relevant point when discussing the contribution of trapping to the contents of an archaeological deposit (e.g. Barham 1981:14-15; Harris et al. 1985:47). Trap complexes such as those at Point Parker, Bayley Point and Scraggy Point, as well as Brewarrina, Toolondo and Lake Condah probably did provide large returns, requiring a considerable degree of social and economic organisation (cf. Altman 1983; Birdsell 1971:344; Daley 1931:25; Dargin 1976:32; Head 1989; Jukes 1847:182; Robins et al. 1995:83, 1998). Nevertheless traps and weirs are at least partially an automatic means of obtaining food, therefore reducing effort and time spent (after construction) and increasing probability of some return. Nevertheless fish traps were culturally important. On Sweers Island, for example, a dulmarra dangka (senior influential male member of the owning patriclan) would traditionally camp close to certain fish traps, to be on guard against wungiji dangka, 'stealing men' - other persons who might sneak in to steal fish and other foods from the traps (Memmott and Trigger 1998:118).

Intertidal zones along the coast can contain stone arrangements with features similar but not identical to fishtraps. These generally comprise small stones (usually less than $20 \mathrm{~cm}$ in diameter) arranged in curvi-linear lines and range in area from less than $100 \mathrm{~m}^{2}$ to large complexes covering thousands of square metres. They are located on recent (late Holocene) marine sands and muds in quite backwater areas, usually open areas behind mangrove forest near the upper high-water mark. While many of the sites incorporate funnel-, V- and U-shaped features characteristic of tidal fishtraps they are unlikely to function simply as 'subsistence' facilities. McNiven (2004:339:Figures 2-3, Plates 1-2) identifies four features suggesting they were not conducive to catching fish. First, many of the V-and U-shaped features are small in area and face the wrong direction to trap fish (i.e. apertures face the sea). Second, stones forming the sites are often spaced apart with no inter-linking walls as would be necessary to trap fish. Third, many of the stone features, such as circles, cairns, and complex mazes, provide no technical aid to trapping. Fourth, the sites tend to be located near the high-water mark areas inundated only episodically with shallow water during exceptionally large tides.

McNiven (2004:339) argues that these inter-tidal stone arrangements were engineered to engage with local tidal waters and tidal forces that were critical to local Aboriginal subsistence and mobility. Tidal waters nourish the vast mangrove forest and mudflats of the region that were key sources of animal and plant foods. In addition, understanding tidal movements was essential for scheduling use of the sea, especially the hazardous and lengthy voyages to offshore islands.

\section{Factors Affecting the Location of Traps and Weirs: Environment and Behaviour}

A number of environmental factors were important in determining the location of a trap or weir with the most obvious factor being the availability of aquatic fauna. That is, if there were no fish then there was no point in building a trap or weir. Moreover, the chance that a trap or weir will catch fish improves with the number of species using the area and the frequency with which they visit (e.g. Thomson 1938:195-196). The ideal location for 
a trap or weir is therefore where there are a high number of species that frequently use the area.

Tides and wave action influence the placing of traps and weirs (Avery 1976:109; also Bird 1992). A trap or weir wall must be high enough to be above water at low tide and thick enough to resist tidal and wave action, which would otherwise undermine the structure. The continual action of tides and waves will damage or destroy a trap or weir in a short time and such structures in a strong tidal or wave zone must be maintained at regular intervals. Therefore, traps and weirs are often placed to make use of natural features that reduce wear. Coastal traps and weirs are usually located on a point, estuary or mudflat and are also common in the vicinity of reefs (cf. Martin 1988:79). They are also found in sheltered areas such as the lee side of islands that also attract fish to forage or breed. Thus placing a trap or weir according to natural features can increase the diversity of the yield (e.g. Coutts et al. 1978:24-25, Memmott n.d. b). Time of year also plays a part in the productivity of a trap or weir. For example, weirs were probably built to capture fish as they moved into estuaries or intertidal streams to spawn. The return from traps and weirs can vary with the movement of fish. Smith (1983:33) argued that part of the reason the Malagun fish trap produced a low yield at the time of recording was because it was the wrong season for fishing.

Since behaviour consists of intangible things like motivation, incentive, preference and expectation it is difficult to determine what motivated people to build traps and weirs. Nevertheless, some behavioural factors can be inferred from the location of a trap or weir. It is obvious that people would not build a trap or weir unless fish were part of their diet. It may not follow, however, that those aquatic resources were a dominant or even major dietary staple of the people who built the trap or weir in question. Nevertheless, it is possible to calculate the importance of aquatic resources in a past diet, relative to other components (Collier and Hobson 1987; Noli and Avery 1988). Using a trap or weir can increase the variety of resources included in a diet and this is an important part of any diet (e.g. Jochim 1976:19-21). The nutritional value of a resource includes meat weight, protein content and energy content with taste being a social equivalent. If people are out foraging for other resources while a trap or weir is left to capture fish, there is potential for a wide array of foods in the diet. If foragers catch or gather what they were after (or even catch or gather something they were not after), and the trap or weir catches some fish, the foragers will have a variety of foods.

The number of traps or weirs in an area may relate to the size of the population that was exploiting resources. As argued above, traps and weirs act to increase production per unit area therefore the more traps or weirs servicing a region, the greater the chance of a return. This, in turn, can be used to accommodate a large population. Nevertheless, it does not follow that a lot of traps mean a large resident population. It may be those additional traps and weirs were built to service temporarily large populations, as might be the case in ceremonies or meetings. Large gatherings of Aboriginal people were frequently reported throughout Queensland for such events (e.g. Morwood 1986; Petrie 1904; Sullivan 1977).
In sum, a trap will increase the size of a catch compared to previous levels but will not continue to increase production. Further, such devices will raise the chance of catching some food but will not guarantee it and people must continue to look for food elsewhere. It seems a trap or weir is limited in what it can provide by a number of factors including design, position and availability of prey. Ultimately the device should be thought of as a back-up to existing foraging strategies rather than an infallible, automatic provider of resources. Nevertheless, the existence of a trap or weir in the archaeological record can be used to interpolate certain behavioural as well as foraging techniques.

\section{Dating Traps and Weirs}

The dating of traps is an ongoing problem in archaeology and relative dating methods are currently the most commonly used method. To date, this has largely been achieved through analysis of environmental conditions or inferences drawn from the content of adjacent archaeological deposits. McNiven (1994:Appendix C), for example, attempted to date the traps at Booral by absolute methods but without success. He argued that shellfish growing on rocks used to build the wall might be preserved within its interstices. Unfortunately he did not find shell in his excavations and concluded that any residue had long since eroded (see Dortch et al. 2006 for a similar attempt in the southwest of Western Australia).

Physical environmental changes have also been used to estimate the age of traps and weirs. Head (1989), for example, estimated that fish traps at Lake Condah, in western Victoria, may have been built prior to $8000 \mathrm{BP}$ and were most probably built after $4000 \mathrm{BP}$ when the lake was at its peak and probably used in the last 2000 years with continuous occupation. Builth et al. (2008:423) more recently have suggested that damming of the lake and construction of the associated weir was undertaken c.4600 years ago. However, it is unlikely that all 78 traps were built at the one time (cf. Coutts et al. 1978:180-181; Van Waarden and Wilson 1994). A series of traps at Broke Inlet on the Shannon River, Western Australia, which no longer function because a nearby sand bar was protecting the inlet from tidal movement has been dated by Dortch (1997:28) to the arrival of the sand bar at 4000 BP (Dix and Meagher 1976:180-181).

It is common for archaeologists to claim that a nearby midden is the same age as the fish trap with which it is associated, or even results from a trap or weir and therefore is the same age as the midden (e.g. Campbell 1982:105; Colhoun and Piper 1982:118; Martin 1988:83; Ulm 2004, 2006; Vale 2000). However developing a convincing method to demonstrate such an association has yet to be devised. A review of the Booral traps and middens by Bowen (1998) used both environmental context and change in the archaeological deposit in an attempt to date the traps. The strength of this combined environmental-behavioural dating is a degree of resolution greater than environment or behaviour would provide if considered alone. If further experiment shows the approach to be viable, archaeologists will be able to establish chronologies for other traps and weirs therefore enabling them to address broader issues such as the origin of these structures. 


\section{Managing Traps and Weirs}

Traps and weirs on the coast and inland waterways of Queensland are a rare site type. Traps with more than one pen occur only in the Torres Strait islands, the southern Gulf of Carpentaria, Hinchinbrook Island and at Booral. Stone weirs are even less common than traps. Most weirs were made of organic materials and have long since decayed. Environmental erosion and/or development will impact over time on the remaining traps and weirs thus making it essential that known structures be thoroughly recorded and managed. Enhanced climate and sea-level changes may hasten the impact of these factors (Rowland 1989, 1992, 1996).

If a trap or weir is located on land or shorelines that have particular values (i.e. aesthetic, economic, military, political or social) then the structure is at risk. A trap or weir may be protected while its surrounding area is developed but it can be the side effects of development that cause the most damage to a site. For example, development may increase the traffic of people through an area, thus impacting on a trap or weir. Further, developing the environment of a trap or weir can sometimes change conditions that previously protected the structure (cf. Bird 1996b:4). Protecting and monitoring a trap or weir must therefore continue after developers have modified an area. Protecting a trap or weir can be as simple as fencing off an area or the placement of signs. Spot-checking of a trap or weir after its immediate area has been developed is important as a way of monitoring the ongoing impacts of development. With few exceptions, traps and weirs in Queensland have been crisis-managed. In most cases where development has threatened a trap or weir, the investigating archaeologist has identified the structure as 'significant' and developers have been directed to avoid it. Such limited intervention is, to some extent, unavoidable. No government department or local government authority has the resources required to monitor each archaeological site in Queensland on a regular basis. However, these factors need not be in conflict with a pro-active management strategy as demonstrated by Border's (1996) plan for the Scraggy Point fish traps.

People have been visiting Scraggy Point for years. It is a popular location for recreational purposes, including fishing and is also a favourite anchorage for yachts and pleasure cruisers (Border 1996:3). The traps attract much public attention and have been sign-posted (Walsh 1986:18). The stone walls have been disturbed over time through anchoring or by the actions of tourists. Moreover, there is a risk of a cyclone or storm surge substantially damaging the traps. Border (1996:5) therefore identified four major management issues: visitor impact, anchor damage, natural impacts and maintenance. He proposed a three-phase management plan for the site. The first phase involved a detailed study of the traps and a programme of public education. The second phase entailed the placing of buoys at the traps to prevent anchoring and included the involvement of local Aboriginal groups to monitor the structures. The third phase proposed an assessment of the plan and its effectiveness. This proposal has few longterm costs and strikes a balance between otherwise expensive preventive measures and personal responsibility on the part of visitors. Nevertheless, the fragile nature of traps and weirs means that their long- term management will remain a challenge. Tides, waves, storm surges or infilling by water-borne sediments (e.g. Bird 1994a:18-19) will eventually undermine a trap or weir. A management plan that does not recognise the limited lifespan of a trap or weir will ultimately fail to protect the site. Therefore, a strategy of recording and research, which considers threats to preservation, is vital (e.g. McNiven 1992).

In some cases Aboriginal or Torres Strait Islander people are still using traps and weirs. The way in which Traditional Owners maintain and manage these structures need to be closely studied and used as guidelines for managing traps and weirs not currently in use. It is possible that Traditional Owners recognise relationships between a trap or weir and other features of the landscape and seascape, which are not obvious to other observers. Any such relationship would be an important consideration for a management plan or recommendation. Traditional management practices contain a wealth of related information about how, when and why a trap or weir is used. This information can be used for educating the public on the role and value of a trap or weir, by means of pamphlets, signs or the electronic media. Moreover, the information has a scientific value as it can serve as a basis for future research.

\section{Future Recording, Management and Monitoring of Traps and Weirs}

It is apparent from the above discussions that Indigenous traps and weirs of Queensland have, with a few exceptions, been poorly studied. A number of survey and recording, research and management options are therefore discussed that would broaden our understanding of these important sites.

First, more surveys of the coast and inland need to be undertaken to record remaining traps and weirs. It is recommended that a standardised convention for recording traps and weirs should be implemented to increase compatibility of resulting site descriptions, and such a convention is proposed in Table 2 . This should be tested and then modified as required. It is suggested that low-level aerial photographs should be taken of all traps and weirs so far listed on the Queensland Indigenous Cultural Heritage Database. A study of the entire Queensland coast should also be undertaken, involving analysis of aerial photographs and ground survey where appropriate. A similar study of inland Queensland should also be undertaken.

The opportunity exists for specific research, involving direct experimentation, to be conducted on traps and weirs (e.g. Keegan 1986; Smith 1983). An ongoing review of the literature and oral histories would further clarify the number, distribution, types and uses of traps and weirs. The development of techniques to distinguish Aboriginal from South Sea Islander and other nonAboriginal traps and weirs needs to be further researched. A study of Pacific Islander and Aboriginal traps and weirs might improve the success of an identificationclassification system. There are a wide-range of issues that could be further investigated such as the rates at which such structures decay, how they decay and what factors cause decay. The productivity of traps and weirs could be much more broadly investigated including how often do traps or weirs get a catch, how many fish are 
caught, what range size/age/sex/species of fish are caught, how these factors vary with time of year and so on. Other issues that could be further investigated include the role of trapping in relationship to other food-getting activities. The origin of traps and weirs and associated material culture needs to be further investigated and this might be assisted by the dating technique discussed by Bowen (1998) which needs to be further tested and developed.

In terms of management there is a need to identify a representative sample of local and regional sites and implement management plans at those levels. More consultation needs to be undertaken with Aboriginal and Torres Strait Islander communities in identifying existing management practices and potential reuse of the trap(s) or weir(s). Sites that are particularly susceptible to adverse impact, like those of Hinchinbrook Island or Booral, should be made the subject of immediate, detailed study. Management plans should include long-term protection measures such as sign-posting, fencing where necessary and spot-checking of a trap or weir. In the event of development, the extent of impact should be monitored and recorded for future reference.

\section{Summary and Conclusions}

Archival, library, graphic and oral references to the presence of traps and weirs in Queensland have been reviewed in this paper. This was done to obtain an overall perspective on the distribution, types, and management needs of these structures. For coastal Queensland, it was concluded that multiple pen traps were common on the Torres Strait islands and at a limited number of locations in the southern Gulf of Carpentaria. With the exception of Hinchinbrook Island and Booral, most traps and weirs south of Torres Strait and the Gulf were isolated structures, with traps having a single pen. Regardless of location on the coast, the walls of traps were most often in the shape of an arc. Similarly, traps and weirs were usually found at points and estuaries and only occasionally on open beaches. The aquatic fauna that were caught by a trap or weir were removed using a variety of techniques including netting, spearing or by hand. It was also found that some traps and weirs on the coast were built or used by non-Aboriginal people, including South Sea Islanders. The task of identifying whom may have built the various traps and weirs were identified as a problem that requires further investigation. Less information could be located on traps and weirs of inland Queensland. It appears that inland Queensland had many organic traps and weirs, which might indicate that aquatic resources were available for short periods. The only apparent consistency to their distribution is that weirs were common east of the Great Dividing Range, while traps were common to the west. A narrow range of material items was observed in association with inland traps and weirs; aquatic fauna was collected by baskets, cages, platforms and nets.

A number of points were made in respect to the classification and distribution of traps and weirs. First, it was found that traps and weirs were built or used by a number of non-Aboriginal and Torres Strait Islander groups, including South Sea Islanders and Europeans. Associating traps and weirs with the group that built or used it is confounded by the seeming universality of shape and design among these structures. Second, most traps and weirs on the coast are located between Cairns and Mackay, at the southern Gulf of Carpentaria or among the Torres Strait islands. Third, traps and weirs were generally found on low energy coastlines that are protected from strong tides and waves. It is unclear whether traps and weirs were only built in protected areas or that the structures in these areas had survived longer than those in less protected areas. Finally, there are no apparent consistencies in the distribution of traps and weirs for inland Queensland. Traps and weirs were generally widespread throughout inland Queensland with the exception of the Mitchell Grass Downs where they were notably absent.

In considering the role of traps and weirs in food production, it was argued that a single-pen trap or weir probably brought a modest increase to a group's food supply but did not greatly increase production. However, this might not be the case for traps of a larger scale, such as Scraggy Point, Booral, and certain traps of the Torres Strait and the Gulf that may well have increased production. Nevertheless, a group that builds a trap or weir has a greater chance of catching some food although it is not a certainty.

It was found that traps or weirs reveal much information concerning the environment and human behaviour, which may be used to date a site. It was also concluded that traps and weirs are a rare site type, which can be adversely affected by the pressures of development and the environment; thus, there is a need for recording and managing. There are provisions under various State and Federal legislation, policies and procedures to manage traps and weirs yet, with occasional exceptions, most have been crisis-managed. Most management plans or recommendations have protected traps and weirs but have ignored the other priorities of long-term research and monitoring.

Several broader themes came of this study that requires further attention. These themes are identified below. Nets, spears, poisons, baskets, cages and platforms were used in association with traps and weirs. These items may be of some use in solving the problems of identification and classification discussed above. It may be that the different groups who used traps or weirs each had specific ways of extracting fish caught in traps and weirs. Moreover, any difference might be evident in the items people used to take fish from the trap or weir. For example, some Aboriginal groups used spears to take fish from their traps whereas Melanesians often used nets or hand lines. If it can be shown that such differences existed, research of museum collections could be instrumental in identifying the builders of a trap or weir as well as the period in which they used the structure. Such a study would add a new depth to the current understanding of fishing techniques used in conjunction with traps and weirs. It might also define the distribution of traps and weirs as well as particular extractive techniques.

The capacity of a trap or weir to produce food was explored but it was the mechanical aspect of trapping that received the most attention. The human aspects of food production still require defining. Social factors (the 'why' of production) can determine the size, shape, position and evolution of a trap or weir as well as when it was used and by whom. Discussion with Aboriginal and Torres Strait Islander communities is better placed to 
characterise these factors than archaeology; yet apart from studies among the Wellesley Islands and adjoining mainland, little information has been gathered on the human aspect of trapping. Observations of traps and weirs recorded during the frontier period can provide only the most superficial statements concerning social factors. Anthropological studies must begin in the near future before information is permanently lost.

It was argued that traps and weirs were unevenly spread along the Queensland coast and that there was no apparent consistency to their inland distribution. However, the current distribution of traps and weirs might be misleading since those built of organic materials may have decayed. The key question is whether organic and inorganic traps and weirs overlapped within a group's territory. In other words, did people build stone and brush traps and weirs in the same place, wherever they built, or did they build stone traps in one place and organic traps in another? This is an important consideration with significant implications. If organic and inorganic traps and weirs overlapped within a group's territory then, the distribution of traps and weirs today is virtually the same as it was in the frontier period. However if organic and inorganic traps and weirs did not overlap within a group's territory, their present distribution might be unrepresentative. In other words, the traps and weirs that can be observed today might be the remnants of a widespread network, which has since lost its organic component to decay. Certainly there are many examples of organic traps and weirs that were observed in the frontier period and have since disappeared. Nevertheless, this argument must be carefully considered as it is based on negative evidence. It is acceptable to argue sites were 'once there, now gone' but first one must show that sites were 'once there'. Such an undertaking would require a detailed study of historical records to quantify distribution of traps and weirs throughout the frontier period.

The interpretation of traps and weirs as archaeological and historical structures, or, indeed, as manageable resources has been distinctly biased toward a European perspective. The views of Aboriginal or Torres Strait Islander people are poorly represented in the available data, as are their techniques for managing traps and weirs. This is most obvious when it comes to discussing how traps and weirs were used and what role they played in the organisation of food-getting activities. Without reference to the experiences and knowledge of Traditional Owners, researchers are forced to interpret from limited data. Furthermore, the under-representation of their views withholds official recognition from Aboriginal and Torres Strait Islander people and denies them a stake in the ongoing management of these important sites.

Perhaps the clearest conclusion drawn from this review is the generally poor level of recording of known fish traps. Only in the Gulf Country have Connah and Jones (1983) undertaken low level aerial photography. In the Gulf Country and on Hinchinbrook Island Robins et al. (1985,1998) and Campbell (1982) have undertaken systematic surveys respectively. Some sites in the Torres Strait have been drawn from high-level aerial photography but have not been ground-truthed. The majority of fish traps remain reported as often very poor sketch maps with limited photographic coverage. There is therefore a need to undertake a detailed survey of these sites using low-level aerial photography and groundtruthing. Techniques such as GPS mapping may also be useful (e.g. Dare 1994). In the long-term whether or not enhanced climate/sea level change has an impact on these sites they will be destroyed by natural and human impacts.

\section{Acknowledgements}

The project on which this paper is based was funded by a grant from the Australian Heritage Commission 1994-1995 National Estate Grants Program awarded to Mike Rowland. The then Environmental Protection Agency provided facilities that enabled Greg Bowen and Mike Rowland to undertake the initial research on which this paper was based. The initial findings were reported in Bowen and Rowland (1999). Cameo Dalley of The University of Queensland greatly assisted with recent updates and checking of Appendix A and Meredith Roe, Project Officer, Cultural Heritage Coordination Unit, Department of Environment and Resource Management prepared the site maps. This research was supported in part by the Australian Research Council's Discovery Projects funding scheme (project number DP0663047).

A number of people assisted with this project and we would like to express our thanks to them. Clive Moore of the Department of History, The University of Queensland, provided advice on the history of South Sea Islanders in Queensland. The staff of the John Oxley Library and the Fryer Library, The University of Queensland, assisted with references and advice. Monica Garner of the then Environmental Protection Agency Library was instrumental in obtaining reports, articles and books through inter-library loan. Danielle Burette of the then Department of Natural Resources, Mines and Water assisted with further reference material. Helen Cooke of the South Australia Department of State Aboriginal Affairs, and Sharon Veale of New South Wales National Parks and Wildlife Service provided information and contacts. Ian McNiven, Val Attenbrow, Anne Clarke, Peter Hiscock, Garrick Hitchcock and Paul Memmott generously provided feedback or advice on a number of issues. Thanks are also due to all those who allowed their unpublished work to be cited in this volume.

For permissions to reproduced photographs and figures, we thank Bryce Barker, Michele Bird, Melissa Carter, Graham Connah, Alan Jones, Richard Robins, Anthony Barham, John Richter and Cambridge University Press.

Special thanks are due to all those staff of the Cultural Heritage Branch, Queensland then Environmental Protection Agency and Cultural Heritage Coordination Unit, then Department of Natural Resources, Mines and Water who have assisted with this report in a practical way and who gave support and encouragement. Dr Nicky Horsfall in particular provided a critical analysis of an initial draft of the Bowen and Rowland report and Andrew Border has provided more recent first-hand observations on some of the sites mentioned in the text.

Finally, a special thanks to Isabel Tarrago (Director, Cultural Heritage Coordination Unit, Department of Environment and Resource Management) for supporting updating of this report to its current form.

\section{References}

Alfredson, G. 1995 A Cultural Heritage Assessment of Hays Inlet Environmental Park Redcliffe City. Unpublished report to Chenoweth and Associates Pty Ltd, Brisbane.

Allen, J. and P. Corris (eds) 1977 The Journal of John Sweatman: A Nineteenth Century Surveying Voyage in North Australia and Torres Strait. St Lucia, QLD: University of Queensland Press.

Altman, J. 1983 Eastern Gunwinggu fish trapping at Gunbatgarri. The Beagle 1:59-71. 
Anonymous 1990 Oyster man sets record straight. Bribie Island Weekly 8 February 1990.

Avery, G. 1976 Discussion on the age and use of tidal fish-traps (Visvywers). South African Archaeological Bulletin 30:105113.

Balme, J. 1983 Prehistoric fishing in the Lower Darling, western New South Wales. In C. Grigson and J. Clutton-Brock (eds), Animals and Archaeology: 2: Shell Middens, Fishes and Birds, pp.19-32. BAR International Series 183. Oxford: British Archaeological Reports.

Banfield, E.J. 1909 Blacks as fishermen: Expedients, devices, stratagems. Queensland Geographical Journal 24:43-62.

Banfield, E.J. 1977 The Confessions of a Beachcomber. Melbourne: Angus and Robertson.

Bannerman, N. and C. Jones 1999 Fish-trap types: A component of the maritime cultural landscape. International Journal of Nautical Archaeology 28(1):70-84.

Barham, A.J. 1981 Land Use and Environmental Change in the Western Torres Strait Islands, Northern Queensland, Australia. Unpublished report to Queensland Department of Environment, Brisbane.

Barham, A.J. 2000 Late Holocene maritime societies in the Torres Strait Islands, northern Australia-cultural arrival or cultural emergence. In S. O'Connor and P. Veth (eds), East of Wallace's Line: Studies of Past and Present Maritime Cultures of the Indo-Pacific Region, pp.223-314. Rotterdam: AA Balkema.

Barham, A., M. Rowland and G. Hitchcock 2004 Torres Strait bepotaim: An overview of archaeological and ethnoarchaeological investigations and research. In I. McNiven and M. Quinnell (eds), Torres Strait Archaeology and Material Culture, pp.1-72. Memoirs of the Queensland Museum, Cultural Heritage Series 3(1). Brisbane: Queensland Museum.

Barker, B.C. 1988 A Preliminary Archaeological Survey of the Proposed Aqua Del Ray Resort, Midge Point, Pioneer Shire Whitsunday, Central Queensland Coast. Unpublished report to Sinclair Knight and Partners Pty Ltd.

Barker, B.C. 1992a An Assessment of the Cultural Heritage Values of the Mainland Coast of the Whitsunday Region Extending from George Point to Repulse Bay. Unpublished report to the Queensland Department of Environment and Heritage, Brisbane.

Barker, B.C. 1992b An Assessment of the Heritage Sites in the Whitsunday Region as Part of the Whitsunday Regional Management Plan. Unpublished report to the Queensland Department of Environment and Heritage, Brisbane.

Barker, B. and R. Bernard 2007 Fishtraps on the Central Queensland Coast: Bowen to Sarina: An Assessment of their Condition, Significance and Future Impacts. Unpublished report to Mackay/Whitsunday Natural Resource Group.

Barker, B., L. Lamb and Gudjuda Aboriginal Reference Group 2010 Juru spirituality and ceremony: Preliminary results of excavations associated with salt flat stone arrangements at Mine Island, central Queensland coast. In S.K. May, M. Travers and M. Berry (eds), Australian Archaeological Association Annual Conference - Programme and Abstracts, pp.79-80. Adelaide: Griffin Press.

Beale, E. 1983 Kennedy the Barcoo and Beyond 1847: The Journals of Edmund Besley Court Kennedy and Alfred Allatson Turner with New Information on Kennedy's Life. Hobart: Blubber Head Press.
Bird, M.K. 1987 Life's a Beach: A Preliminary Investigation of the Coastal Archaeology of Wunjunga (Beach Mount), Upstart Bay, North Queensland. Unpublished BA (Hons) thesis, Department of Behavioural Sciences, James Cook University, Townsville.

Bird, M.K. 1992 The impact of tropical cyclones on the archaeological record: An Australian example. Archaeology in Oceania 27(2):75-86.

Bird, M.K. 1994a Archaeological Assessment of the Proposed Mission Beach Harbour Pty Ltd Development Site, Clump Point, Mission Beach. Unpublished report to Mission Beach Harbour Pty Ltd, Brisbane.

Bird, M.K. 1994b Cultural Heritage Assessment of the Proposed Port Hinchinbrook Resort Development Site, Oyster Point, North Queensland. Unpublished report to Queensland Department of Environment and Heritage, Brisbane.

Bird, M.K. 1996a Report on the Cultural Heritage Assessment of a Proposed Radio Communications Development Site, Bentinck Island, Southern Gulf of Carpentaria. Unpublished report to Telstra, Brisbane.

Bird, M.K. 1996b Appendix to Archaeological Assessment Report: Dalrymple Bay Coal Terminal and Hay Point Coal Terminal Mackay, Central Queensland. In Port of Hay Point Draft Impact Assessment Study (IAS) Analysis of Submissions \& Supplementary Information. Unpublished report to Ports Corporation of Queensland, Brisbane.

Bird, M. 2009 Cultural Heritage Impact Assessment Study Port of Abbot Point x110 Infrastructure Development Project. Unpublished report to GHD Pty.

Bird, M. 2010 Addendum Cultural Heritage Report Port of Abbot Point Proposed Multi Cargo Facility (MCF) Project. Unpublished report to GHD Pty Ltd.

Bird, R.B., D.W Bird,. and J.M. Beaton, 1995 Children and traditional subsistence on Mer (Murray Island), Torres Strait. Australian Aboriginal Studies 1:2-17.

Birdsell, J.B. 1971 Ecology, spacing mechanisms and adaptive behaviour in Aboriginal land tenure. In R. Crocombe (ed.), Land Tenure in the Pacific, pp.334-361. Melbourne: Oxford University Press.

Black, R. 1995 A Cultural Resource Management Plan for the Tallebudgera Greenspace. Unpublished report to the Queensland Department of Environment and Heritage, Brisbane.

Border, A. 1992 NIAS Northumberland Island Archaeological Surveys (1991). (NEGP 1991/93: Great Barrier Reef Marine Park Archaeological Project, Stage 1 Survey). Unpublished report to Queensland Department of Environment and Heritage, Brisbane.

Border, A. 1994 An Overview Study of Aboriginal and Historic Cultural Heritage Resources in the Teemburra Creek Dam Irrigation Water Demand Areas, Pioneer River Valley, Central Queensland and a Plan for their Management. Unpublished report to CMPS \& F, Brisbane.

Border, A. 1996 The Haven (Scraggy Point) Aboriginal Stone Fish Trap, Hinchinbrook Island: Draft Management Plan. Unpublished report to Queensland Department of Environment, Brisbane.

Border, A. and H.J. Hall. 1994 An Archaeological Survey of Cape Hillsborough National Park, Central Queensland Coast. Unpublished report to the Australian Heritage Commission and the Queensland Department of Environment and Heritage, Brisbane. 
Bottoms, T. 1990 Malanbarra Aboriginal Corporation Five Year Plan. Unpublished report by Yalga-binbi Institute for Community Development in consultation with Malanbarra Aboriginal Corporation.

Bowen, G.M. 1998 Towards a generic technique for dating stone fish traps and weirs. Australian Archaeology 47:39-43.

Bowen G.M. and M.J. Rowland. 1999 Indigenous Traps and Weirs of Queensland: An Overview, Assessment and Recommendations. Unpublished report to the Australian Heritage Commission, Canberra, and Department of Environment, Brisbane.

Boyd, A.J. 1895 Narrative of Captain G. Pennefather's exploration of the Coen, Archer and Batavia Rivers, and of the islands of the western coast of the Gulf of Carpentaria in 1880. Proceedings and Transactions of the Royal Geographical Society of Australasia, Queensland Branch 11:46-61.

Brayshaw, H.C. 1977 Aboriginal Material Culture in the Herbert/Burdekin District, North Queensland. Unpublished $\mathrm{PhD}$ thesis, Department of History, James Cook, Townsville.

Brayshaw, H.C. 1990 Well Beaten Paths: Aborigines of the Herbert Burdekin District, North Queensland: An Ethnographic and Archaeological Study. Townsville: Department of History James Cook University of North Queensland..

Britnell, D. 1991 Out of Site - Out of Mind, DHIIDHAARR, People, Sites and Places at Cape Bedford, Hopevale, North Queensland. Unpublished BA (Hons) thesis, Department of Anthropology and Archaeology, James Cook University, Townsville.

Builth, H., A.P. Kershaw, C. White, A. Roach, L. Hartney, M. McKenzie, T. Lewis and G. Jacobsen 2008 Environmental and cultural change on the Mt Eccles lava-flow landscapes of southwest Victoria, Australia. The Holocene 18(3):413424.

Burke, C. 1993 A Survey of Aboriginal Archaeological Sites on the Curtis Coast, Central Queensland. Unpublished report to the Queensland Department of Environment and Heritage, Brisbane.

Campbell, J.B. 1979 Settlement patterns on offshore islands in north-eastern Queensland. Australian Archaeology 9:18-32.

Campbell, J.B. 1982 Automatic seafood retrieval systems: The evidence from Hinchinbrook Island and its implications. In S. Bowdler (ed.), Coastal Archaeology in Eastern Australia, pp.96-107. Canberra: Research School of Pacific Studies, Australian National University Press.

Campbell, V. 1978 Two fishtraps located on the mid-north coast of New South Wales. In I. McBryde (ed.), Records of Times Past, pp.122-134. Canberra: Australian Institute of Aboriginal Studies.

Clarke, P.A. 2002 Early Aboriginal fishing technology in the Lower Murray, South Australia. Records of the South Australian Museum 35(2):147-167.

Codrington, R.H. 1891 The Melanesians: Studies in their Anthropology and Folk-Lore. Oxford: Clarendon Press.

Coleman, J. 1982 A new look at the north coast: Fish traps and 'villages'. In S. Bowdler (ed.), Coastal Archaeology in Eastern Australia, pp.1-10. Canberra: Department of Prehistory, Research School of Pacific Studies, Australian National University.
Colhoun, E.A. and A. Piper 1982 Stone fishtraps at Cooks Corner, Freycinet Peninsula, Eastern Tasmania. Australian Archaeology 14:115-118.

Collier, S. and K.A. Hobson 1987 The importance of marine protein in the diet of coastal Australian Aboriginals. Current Anthropology 28:559-564.

Colliver, F.S. 1970 A survey of monuments and antiquities in Queensland. In F.D. McCarthy (ed.), Aboriginal Antiquities in Australia, pp.3-14. Canberra: Australian Institute of Aboriginal Studies.

Connah, G. and A. Jones 1983 Aerial archaeology in Australia. Aerial Archaeology 9:1-23.

Connaway, J.M. 2007 Fishweirs: A World Perspective with Emphasis on the Fishweirs of Mississippi. Archaeological Report 33, Mississippi: Mississippi Department of Archives and History, Jackson.

Coutts, P.J.F., R.K. Frank and P.J. Hughes 1978 Aboriginal engineers of the Western District, Victoria. Records of the Victorian Archaeological Survey 7. Melbourne: Victorian Archaeological Survey.

Coyyan 1918 The Aboriginals (for the "Post" and "Herald") IX Their Food. The Northern Herald Thursday May 21918.

Creighton, C. 1984 Keppel Islands Environmental Survey: A Baseline for Archaeological Reconstruction and Resource Management. Unpublished manuscript, Queensland Department of Environment, Brisbane.

Cribb, R. 1997 Report on the Cultural Heritage Survey for False Cape, Cairns, Far North Queensland. Unpublished report to Trinity Cove Resorts Pty Ltd, Brisbane.

Daley, C. 1931 Food of the Australian Aborigines. Victorian Naturalist 48:23-31.

Dare, P. 1994 Mapping ancient Saxon fish traps using GPS. GPS World 5(2)28-29, 32-34, 36.

Dargin, P. 1976 Aboriginal Fisheries of the Darling-Barwon Rivers. Brewarrina: Brewarrina Historical Society.

Dix, W.C. and S.J. Meagher. 1976 Fish traps in the south-west of Western Australia. Records of the Western Australian Museum 4:171-187.

Done, J. 1929 Mitchell River. Queensland Geographical Journal 42-44:64-68.

Dortch, C.E. 1997 New perceptions of the chronology and development of Aboriginal fishing in south-western Australia. World Archaeology 29:15-35.

Dortch, J., C. Dortch and R. Reynolds 2006 Test excavation at the Oyster Harbour stone traps, King George Sand, Western Australia. An investigation aimed at determining the construction method and maximum age of the structures. Australian Archaeology 62:38-43.

Duke, A and S. Collins 1994a Report to Department of Defence Cultural Heritage Survey, Cowley Beach Training Areas.

Duke, A. and S. Collins 1994b Jirrbal Heritage and History Project Cultural Mapping. Unpublished report to Jiddabul Aboriginal Corporation, Cairns.

Duncan-Kemp, A.M. 1968 Where Strange Gods Call. Brisbane: Smith and Paterson.

Flecker, P.O. 1951 Remains of Aboriginal habitation on the Great Barrier Wall. North Queensland Naturalist 19:1-3. 
Flinders, M. 1814 A Voyage to Terra Australis: undertaken for the purpose of completing the discovery of that vast country, and prosecuted in the years 1801, 1802, and 1803, in His Majesty's ship the Investigator ...2 Vols, London.

Flood, J. 1988 Archaeology of the Dreamtime. Sydney: Collins Publishers.

Foley, S.P. 1992 Aboriginal Cultural Heritage Location of Sites of Significance to the Aboriginal Community Great Sandy Region, Southeastern Queensland. Brisbane: Unpublished report to Queensland Department of Environment and Heritage.

Frankland, K. 1990 Booral: A Preliminary Investigation of an Archaeological Site in the Great Sandy Strait Region, Southeast Queensland. Unpublished BA (Hons) thesis, Department of Anthropology and Sociology, University of Queensland, Brisbane.

Ghaleb, B. 1990 An Ethnoarchaeological Study of Mabuiag Island, Torres Strait, Northern Australia. Unpublished PhD thesis, Institute of Archaeology, University College, London.

Gill, E.D. 1970 Aboriginal antiquities of Victoria. In F.D McCarthy (ed.), Aboriginal Antiquities in Australia, pp.2733. Australian Institute of Aboriginal Studies, Canberra.

Gistitin, C. 1995 Quite a Colony: South Sea Islanders in Central Queensland 1867 to 1993. Brisbane: ÆBIS Publishing.

Godwin, L. 1988 Around the traps: A reappraisal of stone fishing weirs in northern New South Wales. Archaeology in Oceania 23(2):45-59.

Godwin, L. 1992 Inspection of Fishtrap, Burnett Heads (KE:A22), 5.8.92. Unpublished manuscript of Queensland Department of Environment and Heritage, Brisbane.

Haddon, A.C. 1912 Reports of the Cambridge Anthropological Expedition to Torres Straits. Vol 4 Arts and Crafts. Cambridge: Cambridge University Press.

Haddon, A.C. 1935 Reports of the Cambridge Anthropological Expedition to Torres Strait, Vol 1. Cambridge: Cambridge University Press.

Hale, H.H. and N.B. Tindale 1933 The Aborigines of Princess Charlotte Bay, North Queensland: Part 1. Records of the South Australian Museum 5:64-116.

Harris, D.R. 1977 Subsistence strategies across Torres Strait. In J. Allen, J. Golson and R. Jones (eds), Sunda and Sahul, pp.421-463. London: Academic Press.

Harris, D.R., A.J. Barham and B. Ghaleb 1985 Archaeology and Recent Palaeo-Environmental History of Torres Strait, Northern Australia; Part IIA of the Torres Strait Research Project. Unpublished report to the Research and Exploration Committee of the National Geographic Society, Brisbane.

Hatte, E. 1997 Final Report Palm Island Rock Art Protection Study. Grant Nos R93/469 and R94/4904. Report to Australian Institute of Aboriginal and Torres Strait Islander Studies, Canberra.

Hatte 2007. Reference will then be on page 49 Hatte, E. 2007 Indigenous Cultural Heritage Study, Phase 2, of the Halifax Bay Defence Practice Area (HBDPA), Department of Defence.

Hatte, E. and N. Heijm 1999 An Assessment of the Cultural Heritage Values of the Halifax Bay Defence Practice Area. Unpublished report to PPK Environment and Infrastructures Pty Ltd, Brisbane.
Hatte, E. and Manbarra Nangarra Wangarra Aboriginal Corporation 2009 An Assessment of the Cultural Heritage Values of a Section of South Eastern Great Palm Island. Unpublished report to Queensland Department of Environment and Resource Management.

Head, L. 1989 Using palaeoecology to date Aboriginal fish traps at Lake Condah, Victoria. Archaeology in Oceania 24:110115.

Hill, I.W. 1981 An Archaeological Report on the Bowen Refinery Area (Comalco Ltd). Unpublished report to Queensland Department of Aboriginal and Islanders' Advancement, Brisbane.

Hiscock, P. and S. Mitchell 1993 Stone Artefacts Quarries and Reduction Sites in Australia: Toward a Profile. Australian Heritage Commission Technical Publication Series 4. Canberra: Australian Government Publishing Service.

Hogan, K., R Hunt, S., Karabut, , T .Larsen, , R. Luxton, and K Mantle,. 1992 Sandstone Point Fishtrap Impact Assessment Report and Site Management Plan. Unpublished manuscript of the Faculty of Applied Science, University of Queensland (Gatton College).

Hornell, J. 1950 Fishing in Many Waters. Cambridge: Cambridge University Press.

Jack, R.L. 1921 Northmost Australia: Three Centuries of Exploration, Discovery, and Adventure in and Around the Cape York Peninsula, Queensland, Volume II. London: Simpkin, Marshall, Hamilton, Kent \& Co. Ltd.

Jenkins, J.G. 1974 Fish weirs and traps. Folk Life 12:5-19.

Jochim, M.A. 1976 Hunter-Gatherer Subsistence and Settlement: A Predictive Model. San Francisco: Academic Press.

Johannes, R.E. and J.W. MacFarlane 1991 Traditional Fishing in the Torres Strait Islands. Hobart: CSIRO, Division of Fisheries.

Jones, D. 1961 Cardwell Shire Story. Brisbane: Jacaranda Press.

Jukes, J.B. 1847 Narrative of the Surveying Voyage of HMS Fly Commanded by Captain F.P. Blackwood, R.N. in Torres Strait, New Guinea and Other Islands of the Eastern Archipelago During the Years 1842-1846; Together with an Excursion Into the Eastern Part of Java, Volume I. London: Boone.

Keegan, W.F. 1986 The ecology of Lucayan Arawak fishing practices. American Antiquity 51:816-825.

King, M. 1995 Fisheries Biology, Assessment and Management. Oxford: Fishing News Books.

Lauer, P.K. 1979 The museum's role in fieldwork: The Fraser Island study. University of Queensland Anthropology Museum Occasional Papers in Anthropology 9:31-72.

Lawrie, M. 1970 Myths and Legends of Torres Strait. St Lucia, QLD: University of Queensland Press.

Leichhardt, L. 1847 Journal of an Overland Expedition in Australia from Moreton Bay to Port Essington 1844-1845. London: Boone.

Lourandos, H. 1997 Continent of Hunter-Gatherers: New Perspectives in Australian Prehistory. Oakleigh, VIC: Cambridge University Press.

Marks, E.N. 1953 A visit to Murray and Darnley Islands. Queensland Naturalist 14:112-120. 
Martin, S. 1988 Eyre Peninsula and West Coast Aboriginal Fish Trap Survey. Adelaide: Unpublished manuscript of South Australia Department of Environment and Planning.

Massola, A. 1969 Journey to Aboriginal Victoria. Rigsby, Adelaide.

McCarthy, F.D. 1940 Aboriginal Australian material culture: Causative factors in its composition. Mankind 2:241-320.

McConnell, U. 1930a The Wik-Munkan Tribe of Cape York Peninsula, Part I. Oceania 1:97-104.

McConnell, U. 1930b The Wik-Munkan Tribe of Cape York Peninsula, Part II. Oceania 1:181-205.

McGarry, J.M. 1987 Fishtraps in the Mackay District: A Preliminary Investigation. Unpublished BA (Hons) thesis, Department of Prehistory and Anthropology, Australian National University, Canberra.

McKinlay, J. 186? McKinlay's Journal of Exploration in the Interior of Australia, (Burke Relief Expedition). Melbourne: F.F. Bailliere.

McNiven, I.J. 1992 Cultural Heritage Management Plan Great Sandy Region Southeastern Queensland. Unpublished report to Queensland Department of Environment and Heritage, Brisbane.

McNiven, I.J. 1994 Booral: Cultural Heritage Management Plan. Unpublished report to the Queensland Department of Environment and Heritage, Brisbane.

McNiven, I. 2003 Saltwater people: Spiritscapes, maritime rituals and the archaeology of Australian indigenous seascapes. World Archaeology 35(3):329-349.

McNiven, I., T. Denham, P. Kershaw, H. Builth and G. Jacobsen 2009 Antiquity of Gunditjmara Eel Traps Project. Unpublished report to AINSE. Retrieved 17 November 2010 from

http://www.ainse.edu.au/_data/assets/pdf_file/0004/47308/ r_09007.pdf.

Memmott, P. n.d. 'a' Literature Discussion. Unpublished manuscript of Paul Memmott and Associates, Brisbane.

Memmott, P. n.d. 'b' Rock Wall Fish Traps of Wellesley Islands. Unpublished manuscript of Paul Memmott and Associates, Brisbane.

Memmott, P. 1996 Report No 1 on Sacred Sites in the North Wellesley Islands. Unpublished Report to the Department of Environment and Heritage, Brisbane.

Memmott, P., R. Robins and E. Stock 2008 What exactly is a fish trap?: Methodological issues for the study of Aboriginal intertidal rock wall fish traps, Wellesley Islands region, Gulf of Carpentaria, Australia. In Connolly J. and M. Campbell (eds) Comparative Island Archaeologies, pp.73-96. British International Series S1829, Oxford: Archaeopress.

Memmott, P. and Trigger, D.S. 1998 Indigenous marine tenure in the Wellesley Islands Region, Gulf of Carpentaria. In N. Peterson and B. Rigsby (eds), Customary Marine Tenure in Australia, pp.109-124. Oceania Monographs 48. Sydney: Oceania Monographs.

Mercer, P. 1995 White Australia Defied, Pacific Islander Settlement in North Queensland. Studies in North Queensland History 21. Townsville: Department of History and Politics, James Cook University.

Meriam, J.L. and L.G. Kraige, 1987 Engineering Mechanics Volume I, Statics. New York: John Wiley and Sons Inc.
Milne, S. 1990 Food for Thought: A Functional Analysis of the Stone Structures at Mine Island, Cape Upstart. Unpublished BA (Hons) thesis, Division of Anthropology and Archaeology, James Cook University, Townsville.

Mitchell, T.L. 1848 Journal of an Expedition into the Interior of Tropical Australia, in Search of a Route from Sydney to the Gulf of Carpentaria. London: Longman, Brown, Green and Longmans.

Moore, D.R. 1979 Islanders and Aborigines at Cape York: An Ethnographic Reconstruction Based on the 1848-1850 'Rattlesnake' Journals of O.W. Brierly and Information he Obtained from Barbara Thompson. Canberra: Australian Institute of Aboriginal Studies.

Morwood, M. 1986 The archaeology of art: Excavations at Gatton and Maidenwell Rockshelters, S.E. Queensland. Queensland Archaeological Research 3:88-132.

Mulvaney, J. and J. Kamminga. 1999 Prehistory of Australia. Sydney: Allen and Unwin.

Munro, I.S.R. 1972 Introduction and station lists. In The Fauna of the Gulf of Carpentaria, pp.1-38. Fisheries Notes (New Series) 2, Fisheries Branch, Queensland Department of Primary Industries.

Noli, D. and G Avery,. 1988 Protein poisoning and coastal subsistence. Journal of Archaeological Science 15:395-401.

O’Connor, S. and P. Veth 2000 The world's first mariners: Savannah dwellers in an island continent. In S. O'Connor and P. Veth (eds), East of Wallace's Line: Studies of Past and Present Maritime Cultures of the Indo-Pacific Region, pp.99-137. Rotterdam: AA Balkema.

Petrie, C.C. 1904 Tom Petrie's Reminiscences of Early Queensland. Watson, Ferguson \& Co., Brisbane.

Pickard, G.L., J.R. Donguy, C. Henin and F. Rougerie 1977 A Review of the Physical Oceanography of the Great Barrier Reef and Western Coral Sea. Australian Institute of Marine Science Monograph Series 2. Canberra: AGPS.

Rhodes, E.G. 1980 Modes of Holocene Coastal Progradation, Gulf of Carpentaria. Unpublished PhD thesis, Department of Biogeography and Geomorphology, Research School of Pacific Studies, Australian National University, Canberra.

Richardson, N. 1983 A Preliminary Report on Background Research for the Moonie to Jackson Pipeline Archaeology Project. Unpublished report to Archaeology Branch, Queensland Department of Aboriginal and Islanders' Advancement, Brisbane.

Richter, J., O. Murphy, M. McNiven and B. Munn 2006 Report on the Cultural Significance of Piastre Fish Trap. Unpublished report to the Cultural Heritage Coordination Unit, Department of Natural Resources and Water.

Robins, R.P., E.C. Stock and D.S. Trigger 1995 A Report on Geomorphological, Anthropological and Archaeological Investigations of the Coastal Lands from Point Parker to Eight Mile Creek, Southern Gulf of Carpentaria. Unpublished report to Australian Heritage Commission, Canberra, and Queensland Department of Environment and Heritage, Brisbane.

Robins, R.P., E.C. Stock and D.S. Trigger 1998 Saltwater people, saltwater country: Geomorphological, anthropological and archaeological investigations of the coastal lands in the southern Gulf country of Queensland. Memoirs of the Queensland Museum, Cultural Heritage Series 1(1):75-125. 
Ross, P.J. 2009 Ngarrindjeri Fish Traps of the Lower Murray Lakes and Northern Cooroy Estuary, South Australia. Unpublished Master of Maritime Archaeology thesis, Department of Archaeology, Flinders University, Adelaide.

Roth, W.E. 1897 Ethnological Studies Among the North-West Central Queensland Aborigines. Brisbane: Government Printer.

Roth, W.E. 1901 Food, its Search, Capture, and Preparation. North Queensland Ethnography Bulletin 3. Brisbane: Government Printer.

Roughsey, D. 1971 Moon and Rainbow: The Autobiography of an Aboriginal. Sydney: Reed.

Rowland, M.J. 1989 Population increase, intensification or a result of preservation? Exploring site distribution patterns on the coast of Queensland. Australian Aboriginal Studies 2:3242.

Rowland, M.J. 1992 Climate change, sea-level rise and the archaeological record. Australian Archaeology 34:29-33.

Rowland, M.J. 1996 Climate change and its impact on Australia's cultural heritage. In L. Smith and A. Clarke (eds), Issues in Management Archaeology, pp.128-135. Tempus 5. St Lucia, Queensland: Anthropology Museum, University of Queensland.

Rowland, M.J. 2008 Colonization, environment and insularity: prehistoric island use in the Great Barrier Reef Province, Queensland Australia. In J. Connolly and M. Campbell (eds), Comparative Island Archaeologies, pp.85-104. BAR International Series S1829, Oxford: Archaeopress.

Rowlands, R.J. and J.M. Rowlands 1972 Aboriginal Stone Arrangements: Report on Field Work in South Western Queensland June-August, 1972. Unpublished manuscript of Queensland Department of Environment, Brisbane.

Savage, P. 1989 Christie Palmerston, Explorer. Townsville: Department of History and Politics, James Cook University.

Smith, M. 1983 Joules from pools: Social and techno-economic aspects of Bardi stone fish traps. In M. Smith (ed.), Archaeology at ANZAAS 1983, pp.29-45. Perth: Western Australian Museum.

Smith, S. 1998 Freshwater Point Archaeological Survey. (incomplete cover sheet).

Steele, J.G. 1972 Explorers of the Moreton Bay District 17701830. St Lucia, Queensland: University of Queensland Press.

Stephens, S.E. 1945 Relics of the Hinchinbrook Island Aborigines. The North Queensland Naturalist 7:1-3.

Stephens, S.E. 1946 An Aboriginal fish trap. The North Queensland Naturalist 8:1-3.

Stockton, J. 1975 An Aboriginal fishtrap from southern Queensland? Mankind 10:44-45.

Stockton, J. 1982 Stone wall fish-traps in Tasmania. Australian Archaeology 14:107-114.

Sturt, C. 1849 Narrative of an Expedition into Central Australia, Performed under the Authority of Her Majesty's Government, during the Years 1844, 5 and 6. Together with a Notice of the Province of South Australia, in 1847, Volume II. London: T. and W. Boone.

Sullivan, H. 1977 Aboriginal Gatherings in Southeast Queensland. Unpublished BA (Hons) thesis, Australian National University, Canberra.
Sutton, P. 1994 Material culture traditions of the Wik People, Cape York Peninsula. Records of the South Australian Museum 27(1):31-52.

Sutton, S. 1986 A Report on an Archaeological Survey of Hinchinbrook Island and some Considerations of the Island's Prehistory. Unpublished manuscript of the Queensland Department of Environment, Brisbane.

Tenison-Woods, J.E. 1882 A visit to the Wild River. The Sydney Mail March 1882.

Thomson, D.F. 1936 Notes on some bone and stone implements from North Queensland. The Journal of the Royal Anthropological Institute of Great Britain and Ireland 66:71-74.

Thomson, D.F. 1938 A new type of fish trap from Arnhem Land. Man 38:193-198.

Tindale, N.B. 1962 Geographical knowledge of the Kaiadilt People of Bentinck Island. Records of the South Australian Museum 14:259-296.

Tindale, N.B. 1974 Aboriginal Tribes of Australia. Los Angeles: University of California Press..

Trigger, D.S. 1987 Inland, coast and islands: Traditional Aboriginal society and material culture in a region of the southern Gulf of Carpentaria. Records of the South Australian Museum 21:69-84.

Ulm, S. 2004 Themes in the archaeology of mid-to-late Holocene Australia. In T. Murray (ed.), Archaeology from Australia, pp.187-208. Melbourne: Australian Scholarly Publishing.

Ulm, S. 2006 Coastal Themes: An Archaeology of the Southern Curtis Coast, Queensland. Terra Australis 24. Canberra: ANU E Press.

Ulm, S. and I. Lilley 1999 The archaeology of the southern Curtis Coast: An overview. Queensland Archaeological Research 11:59-84.

Vale, D. 2000 The Arrawarra beach stone structure: Another perspective. Australian Archaeology 51:67-68.

Van Waarden, N. and R. Wilson 1994 Developing a hydrological model of the Lake Condah fish traps in western Victoria using GIS. In I. Johnson (ed.), Methods in the Mountains, pp.81-90. Sydney University Archaeological Methods Series 2. Sydney: Archaeological Computing Laboratory.

Walsh, G. 1986 Hinchinbrook Island National Park: Cultural Resource Management and Development. Unpublished report to Queensland National Parks and Wildlife Service, Brisbane.

Walshe, K. 1996 Archaeological Assessment of Possible Aboriginal Fish Trap - River Anacotilla Fish Trap Complex - Anacotilla Beach, Wirrina Cove, South Australia. Unpublished report to South Australian Department of State Aboriginal Affairs, Adelaide.

Walters, I.N. 1985 The Toorbul Point Aboriginal fish trap. Queensland Archaeological Research 2:38-49.

Welz, A.I. 2002 Fish Trap Placement! The Environmental and Cultural influences in Fish Trap Placement along the Australian Coastline. Unpublished BA (Hons) thesis, Department of Archaeology, Flinders University, Adelaide.

Wills, W.J. 1863 A Successful Exploration through the Interior of Australia: From Melbourne to the Gulf of Carpentaria/ from the Journals and Letters of William John Wills/ Edited by his Father, William Wills. London: Bentley. 
Winsor, V. 1982 Island that We Knew. Mackay: Winsor.

Woodford, J. 1996 Dip into History Solves Harbour Mystery. Sydney Morning Herald February 1996.

Wright, B. 1988 Between Two Rivers, the Aborigines of the Leichhardt Gilbert Region of North West Queensland. Cultural Resource Management Monograph Series 7. Brisbane: Department of Community Services.

Wright, W. 1862 Exploring expedition from Victoria to the Gulf of Carpentaria, The Journal of the Royal Geographical Society 32:430-529. 
Appendix A. List of fish traps and weirs registered on the Queensland Indigenous Cultural Heritage Database.

\begin{tabular}{|c|c|c|c|c|c|c|c|c|c|c|}
\hline Site ID & Location & Site Name & Material & Type & Shape $^{1}$ & $\begin{array}{l}\text { No. of } \\
\text { Pens }\end{array}$ & $\begin{array}{l}\text { Length }^{2} \\
\text { (m) }\end{array}$ & $\begin{array}{c}\text { Apex }^{3} \\
\text { (m) }\end{array}$ & $\begin{array}{l}\text { Wall Height }^{4} \\
\text { (cm) }\end{array}$ & $\begin{array}{l}\text { References or } \\
\text { Recorder }^{6}\end{array}$ \\
\hline AM:A07 & Allen Island & Allen Island & Stone & Trap & Arc & 4 & - & - & - & $\begin{array}{l}\text { Connah and } \\
\text { Jones } 1983\end{array}$ \\
\hline AM:A59 & Point Parker & Point Parker & Stone & Trap & $\begin{array}{l}\text { Arc/V/ } \\
\text { Straight }\end{array}$ & 5 & $35 ; 195$ & - & 80 & $\begin{array}{l}\text { Robins et al. } \\
\text { 1995, } 1998\end{array}$ \\
\hline AM:A61 & Bentick Island & $\begin{array}{l}\text { Mackenzie } \\
\text { Creek }\end{array}$ & Stone & Trap & & 5 & & & & Bird 1996a \\
\hline $\begin{array}{l}\text { AN:A01 } \\
\text { (Duplicates } \\
\text { AN:A24) }\end{array}$ & Bayley Point & Gaabula & Stone & Trap & Arc & 8 & $35 ; 175$ & - & 50 & $\begin{array}{l}\text { Connah and } \\
\text { Jones } \\
\text { 1983:Figure } \\
\text { 13; Robins et } \\
\text { al. 1995, } 1998\end{array}$ \\
\hline AN:A02 & Bayley Island & Bayley Island & Stone & Trap & Arc/M? & - & - & - & - & $\begin{array}{l}\text { Connah and } \\
\text { Jones } 1983\end{array}$ \\
\hline AN:A03 & Bayley Island & Bayley Island & Stone & Trap & Arc & - & - & - & - & $\begin{array}{l}\text { Connah and } \\
\text { Jones } 1983\end{array}$ \\
\hline AN:A43 & $\begin{array}{l}\text { Mornington } \\
\text { Island }\end{array}$ & Wiraminhale & Stone & Trap & & & & & & Memmott 1996 \\
\hline BG:A01 & $\begin{array}{l}\text { Burke River, } \\
\text { Boulia }\end{array}$ & Burke River & Stone & Weir? & - & - & 30 & - & - & - \\
\hline $\begin{array}{l}\text { BM:A09/1- } \\
9\end{array}$ & Sweers Island & Sweers Island & Stone & Trap & - & - & - & - & - & $\begin{array}{l}\text { J. Dymock } \\
1987\end{array}$ \\
\hline BN:A09 & $\begin{array}{l}\text { Mornington } \\
\text { Island }\end{array}$ & Gununa & Stone & Trap & Arc & - & - & 120 & - & $\begin{array}{l}\text { K. Sutcliffe \& } \\
\text { P. Smith } 1983\end{array}$ \\
\hline BN:A11 & $\begin{array}{l}\text { Mornington } \\
\text { Island }\end{array}$ & Wurdu & Stone & Trap & Arc? & & & & & Memmott 1996 \\
\hline BN:A21 & $\begin{array}{l}\text { Mornington } \\
\text { Island }\end{array}$ & Nhawalan & Stone & Trap & & & & & & Memmott 1996 \\
\hline $\mathrm{BN}: \mathrm{A} 23$ & $\begin{array}{l}\text { Mornington } \\
\text { Island }\end{array}$ & Wurukura & & Weir & & & & & & Memmott 1996 \\
\hline CB:A10 & $\begin{array}{l}\text { Cooper Creek, } \\
\text { Bulloo }\end{array}$ & Nappamerrie & Stone & Trap & - & - & - & - & - & - \\
\hline CW:A10* & Moa & $\begin{array}{l}\text { South of } \\
\text { Saveka Point } 1\end{array}$ & Stone & Trap & Arc & 1 (trap) & 10 & - & - & Barham 1981 \\
\hline CW:A11 & Moa & $\begin{array}{l}\text { South of } \\
\text { Saveka Point } 2\end{array}$ & Stone & Trap & Arc & 1 (trap) & 53 & - & - & Barham 1981 \\
\hline CW:A12 & Moa & $\begin{array}{l}\text { South Saveka } \\
\text { Point } 3\end{array}$ & Stone & Trap & Arc & 1 (trap) & 74 & - & - & Barham 1981 \\
\hline
\end{tabular}




\begin{tabular}{|c|c|c|c|c|c|c|c|c|c|c|}
\hline Site ID & Location & Site Name & Material & Type & Shape $^{1}$ & $\begin{array}{l}\text { No. of } \\
\text { Pens }\end{array}$ & $\begin{array}{l}\text { Length }^{2} \\
\text { (m) }\end{array}$ & $\begin{array}{c}\text { Apex }^{3} \\
\text { (m) }\end{array}$ & $\begin{array}{c}\text { Wall Height }{ }^{4} \\
\text { (cm) }\end{array}$ & $\begin{array}{c}\text { References or } \\
\text { Recorder }^{6}\end{array}$ \\
\hline CW:A24 & $\begin{array}{l}\text { NW end of } \\
\text { Goods Island }\end{array}$ & Goods Island & Stone & Trap & M? & 1 & - & - & - & - \\
\hline CW:A42* & $\begin{array}{l}\text { NE corner of } \\
\text { Waibene }\end{array}$ & Muralug & Stone & Trap & Rectangular & 1 trap & - & 60 & 1 & - \\
\hline CW:A79* & Brewers Island & Brewers Island & Stone & Trap & $\mathrm{O}$ & 1 trap & & & 50 & \\
\hline CW:A81! & Goods Island & Bertie Bay & Stone & Trap & Rectangular & 1 trap & & & & \\
\hline CW:B03 & Badu & Zigini Point & Stone & Trap & & & & & & Brown 2005 \\
\hline $\begin{array}{l}\text { CX:A03* } \\
\text { (Duplicates } \\
\text { CX:A13) }\end{array}$ & Mabuiag & Kodakal & Stone & Trap & Arc & $\begin{array}{l}1 \text { trap, } 2 \\
\text { pens }\end{array}$ & 104 & - & - & - \\
\hline CX:A06* & Mabuiag & $\begin{array}{l}\text { Sipa Ngur } \\
\text { Headland }\end{array}$ & Stone & Trap & $\begin{array}{l}\text { Arc and } \\
\text { rectangular }\end{array}$ & 2 & $\begin{array}{l}\text { Arc-shaped } \\
\text { trap is } 150\end{array}$ & - & - & $\begin{array}{l}\text { Harris et al. } \\
1985\end{array}$ \\
\hline CX:A15 & $\begin{array}{l}\text { NW corner of } \\
\text { Woeydhul }\end{array}$ & Woeydhul & & & & & & & & Ghaleb 1990 \\
\hline CX:A23 & $\begin{array}{l}\text { Northern coast } \\
\text { of Mabuiag }\end{array}$ & $\begin{array}{l}\text { Mabuiag } \\
\text { Fish Trap } 1\end{array}$ & & & & & & & & Ghaleb 1990 \\
\hline CX:A24 & $\begin{array}{l}\text { Northern coast } \\
\text { of Mabuiag }\end{array}$ & $\begin{array}{l}\text { Mabuiag } \\
\text { Fish Trap } 2\end{array}$ & & & & & & & & Ghaleb 1990 \\
\hline CX:A25 & $\begin{array}{l}\text { Southern tip of } \\
\text { the east } \\
\text { headland of } \\
\text { Mabuiag }\end{array}$ & $\begin{array}{l}\text { Mabuiag } \\
\text { Fish Trap } 3\end{array}$ & & & & & & & & Ghaleb 1990 \\
\hline CX:A26 & $\begin{array}{l}\text { Around the } \\
\text { headland from } \\
\text { Sipa Ngur, SE } \\
\text { Mabuiag }\end{array}$ & $\begin{array}{l}\text { Mabuiag } \\
\text { Fish Trap } 4\end{array}$ & & & & & & & & Ghaleb 1990 \\
\hline CX:A27 & $\begin{array}{l}\text { Southern coast } \\
\text { of Mabuiag }\end{array}$ & $\begin{array}{l}\text { Mabuiag } \\
\text { Fish Trap } 5\end{array}$ & & & & & & & & Ghaleb 1990 \\
\hline CX:A28 & $\begin{array}{l}\text { East coast of } \\
\text { Aipus }\end{array}$ & $\begin{array}{l}\text { Aipus } \\
\text { Fish Trap } 1\end{array}$ & & & & & & & & Ghaleb 1990 \\
\hline CX:A29 & $\begin{array}{l}\text { East coast of } \\
\text { Aipus }\end{array}$ & $\begin{array}{l}\text { Aipus } \\
\text { Fish Trap } 2\end{array}$ & & & & & & & & Ghaleb 1990 \\
\hline CX:A30 & $\begin{array}{l}\text { NE coast of } \\
\text { Puruai }\end{array}$ & $\begin{array}{l}\text { Pururai Fish } \\
\text { Trap } 1\end{array}$ & & & & & & & & Ghaleb 1990 \\
\hline CX:A31 & $\begin{array}{l}\text { SE coast of } \\
\text { Puruai }\end{array}$ & $\begin{array}{l}\text { Puruai Fish } \\
\text { Trap } 2\end{array}$ & & & & & & & & Ghaleb 1990 \\
\hline CX:A32 & Sarabar & $\begin{array}{l}\text { Sarabar Fish } \\
\text { Trap } 1\end{array}$ & & & & & & & & Ghaleb 1990 \\
\hline
\end{tabular}




\begin{tabular}{|c|c|c|c|c|c|c|c|c|c|c|}
\hline Site ID & Location & Site Name & Material & Type & Shape $^{1}$ & $\begin{array}{l}\text { No. of } \\
\text { Pens }\end{array}$ & $\begin{array}{l}\text { Length }^{2} \\
\text { (m) }\end{array}$ & $\begin{array}{l}\text { Apex }^{3} \\
\text { (m) }\end{array}$ & $\begin{array}{l}\text { Wall Height }{ }^{4} \\
\text { (cm) }\end{array}$ & $\begin{array}{l}\text { References or } \\
\text { Recorder }^{6}\end{array}$ \\
\hline CX:A33 & Sarabar & $\begin{array}{l}\text { Sarabar Fish } \\
\text { Trap } 2\end{array}$ & & & & & & & & Ghaleb 1990 \\
\hline DC:A08 & $\begin{array}{l}\text { East of Kyabra } \\
\text { Creek, Quilpie }\end{array}$ & $\begin{array}{l}\text { Thylungra } \\
\text { Homestead }\end{array}$ & Stone & $\begin{array}{l}\text { Weir } \\
\text { Dam }\end{array}$ & - & - & - & - & - & - \\
\hline DL:B03 & $\begin{array}{l}\text { Listed as } \\
\text { confidential }\end{array}$ & $\begin{array}{l}\text { Moon } \\
\text { Dreaming }\end{array}$ & Earth & & & & & & & \\
\hline DX:A27 & Yam Island & Kwod & $\begin{array}{l}\text { Mangrove } \\
\text { stakes }\end{array}$ & Weir & & & & & & $\begin{array}{l}\text { Haddon } \\
\text { 1935:373-378 }\end{array}$ \\
\hline DX:A29* & $\begin{array}{l}\text { Badog Village, } \\
\text { Erub }\end{array}$ & $\begin{array}{l}\text { Badog Fish } \\
\text { Traps } 1 \text { and } 2 \\
\text { (DT28 or } \\
\text { DT29) }\end{array}$ & Stone & Trap & Arc & $\begin{array}{l}2 \text { (each } \\
\text { with a } \\
\text { single pen) }\end{array}$ & - & $\begin{array}{l}\text { Trap 1: } \\
158.5 \\
\text { Trap 2: } \\
114\end{array}$ & $\begin{array}{l}\text { Trap 1:60-80 } \\
\text { Trap 2:40-30 }\end{array}$ & $\begin{array}{l}\text { Barham 2000: } \\
\text { Figure } 6\end{array}$ \\
\hline $\begin{array}{l}\text { DX:A41- } \\
73\end{array}$ & Erub & & Stone & & & & & & & Barham 2000 \\
\hline $\begin{array}{l}\text { DX:A74- } \\
96\end{array}$ & $\begin{array}{l}\text { Ugar } \\
\text { (Stephens) } \\
\text { Island) }\end{array}$ & ST1-ST23 & Stone & Trap & Various & 23 traps & & & & $\begin{array}{l}\text { Barham 2000; } \\
\text { Johannes \& } \\
\text { MacFarlane } \\
1991\end{array}$ \\
\hline EB:A01* & $\begin{array}{l}\text { Manu Manu } \\
\text { Creek off } \\
\text { Bulloo River, } \\
\text { south of } \\
\text { Quilpie }\end{array}$ & Piastre 1 & Stone & Trap & $\begin{array}{l}\text { Arc/V- } \\
\text { shapes }\end{array}$ & $\begin{array}{l}1 \text { trap } \\
\text { number of } \\
\text { pens }\end{array}$ & $150 \mathrm{~m}$ in total & - & $70-80$ & $\begin{array}{l}\text { Richter et al } \\
\text { 2006; } \\
\text { Rowlands \& } \\
\text { Rowlands } 1972\end{array}$ \\
\hline EC:A15 & $\begin{array}{l}\text { Bulloo River, } \\
\text { Harrington } \\
\text { Station, } \\
\text { Quilpie }\end{array}$ & Nickavilla & - & Trap & - & - & - & - & - & - \\
\hline EL:A02 & $\begin{array}{l}\text { Glenlofty } \\
\text { Creek, Graigs } \\
\text { Pocket Station, } \\
\text { Mt Garnet }\end{array}$ & Craigs Pocket & Stone & Weir & Arc & 1 trap/pen & 8 & 4 & 0.5 & Brayshaw 1977 \\
\hline EN:C33 & $\begin{array}{l}\text { Western end of } \\
\text { Snapper Island, } \\
\text { off Cape } \\
\text { Kimberley }\end{array}$ & & Stone & Trap & & & & & & \\
\hline EP:A81! & $\begin{array}{l}\text { Quarantine } \\
\text { Bay, Cooktown }\end{array}$ & $\begin{array}{l}\text { Monkhouse } \\
\text { Point }\end{array}$ & Stone & Trap & Arc & 1 trap/pen & - & - & - & Britnell 1991 \\
\hline
\end{tabular}




\begin{tabular}{|c|c|c|c|c|c|c|c|c|c|c|}
\hline Site ID & Location & Site Name & Material & Type & Shape $^{1}$ & $\begin{array}{l}\text { No. of } \\
\text { Pens }\end{array}$ & $\begin{array}{l}\text { Length }^{2} \\
\text { (m) }\end{array}$ & $\begin{array}{l}\text { Apex }^{3} \\
\text { (m) }\end{array}$ & $\begin{array}{c}\text { Wall Height }{ }^{4} \\
\text { (cm) }\end{array}$ & $\begin{array}{c}\text { References or } \\
\text { Recorder }^{6}\end{array}$ \\
\hline FA:A12* & $\begin{array}{l}\text { Nebine River, } \\
\text { Murra Murra } \\
\text { Station, } \\
\text { Cunnamulla }\end{array}$ & Bendee Downs & Stone & Trap? & - & - & - & - & - & $\begin{array}{l}\text { Richardson } \\
1983\end{array}$ \\
\hline FE:A10* & $\begin{array}{l}\text { Upper Barcoo } \\
\text { River, Cheshire } \\
\text { Station, Tambo }\end{array}$ & Cheshire & Stone & Weir & Arc & 1 trap/pen & - & - & - & - \\
\hline FK:A23* & $\begin{array}{l}\text { Great Basalt } \\
\text { Wall, } \\
\text { Fletchervale } \\
\text { Station }\end{array}$ & Fletchervale & Stone & $\begin{array}{l}\text { Trap } \\
\text { (?) }\end{array}$ & Arc & 1 & - & - & 60 & $\begin{array}{l}\text { Brayshaw } \\
\text { 1977; Flecker } \\
1951\end{array}$ \\
\hline FK:A24* & $\begin{array}{l}\text { Great Basalt } \\
\text { Wall, } \\
\text { Fletchervale } \\
\text { Station }\end{array}$ & Fletchervale & Stone & Trap? & $\mathrm{V}$ & 1 & $6 ; 11$ & - & - & $\begin{array}{l}\text { Brayshaw } \\
\text { 1977; Flecker } \\
1951\end{array}$ \\
\hline FK:B27 & $\begin{array}{l}\text { Great Basalt } \\
\text { Wall, Lochwall } \\
\text { Station }\end{array}$ & Lockwall & Stone & Weir? & & & & & & \\
\hline FK:C23 & Herald Island & & Stone & Trap & & & & & & $\begin{array}{l}\text { Hatte and } \\
\text { Heijm } 1999\end{array}$ \\
\hline FK:C25 & $\begin{array}{l}\text { Rattlesnake } \\
\text { Island }\end{array}$ & & Stone & Trap & & & & & & $\begin{array}{l}\text { Hatte and } \\
\text { Heijm } 1999\end{array}$ \\
\hline FK:C80 & $\begin{array}{l}\text { Rattlesnake } \\
\text { Island }\end{array}$ & $\begin{array}{l}\text { Rattlesnake } \\
\text { Island } 2\end{array}$ & Stone & Trap & & & & & $30-40$ & Hatte 2007 \\
\hline FL:A13^! & Oyster Point & & Stone & Trap & - & - & - & - & - & $\begin{array}{l}\text { Bird 1994b; } \\
\text { Campbell } 1982\end{array}$ \\
\hline FL:A23* & $\begin{array}{l}\text { Hinchinbrook } \\
\text { Island }\end{array}$ & Scraggy Point & Stone & Trap & $\mathrm{M}$ & $\begin{array}{l}1 \text { trap, } 2 \\
\text { pens }\end{array}$ & c.135 & - & 50 & $\begin{array}{l}\text { Campbell } \\
\text { 1979, 1982; } \\
\text { Stephens } 1946\end{array}$ \\
\hline FL:A46^** & Goold Island & & Stone & Trap & Arc & 1 & $\sim 80$ & $\sim 52$ & - & $\begin{array}{l}\text { Campbell } \\
\text { 1979, 1982; } \\
\text { Walsh } 1986\end{array}$ \\
\hline FL:A48^! & Oyster Point & $\begin{array}{l}\text { Oyster Point } \\
\text { Fish Trap }\end{array}$ & Stone & Trap & Arc & - & - & - & - & $\begin{array}{l}\text { Bird 1994b; } \\
\text { Campbell } 1982\end{array}$ \\
\hline FL:A49 & $\begin{array}{l}\text { Hinchinbrook } \\
\text { Island }\end{array}$ & $\begin{array}{l}\text { Missionary } \\
\text { Bay }\end{array}$ & Stone & Trap & Arc & 7 traps & - & - & - & $\begin{array}{l}\text { Campbell } \\
\text { 1979, } 1982\end{array}$ \\
\hline FL:C09 & Palm Island & North East Bay & Stone & Trap & - & - & - & - & - & Hatte 1997 \\
\hline FL:C10 & Palm Island & Horseshoe Bay & Stone & Trap & - & - & $200 ?$ & $300 ?$ & - & Hatte 1997 \\
\hline
\end{tabular}




\begin{tabular}{|c|c|c|c|c|c|c|c|c|c|c|}
\hline Site ID & Location & Site Name & Material & Type & Shape $^{1}$ & $\begin{array}{l}\text { No. of } \\
\text { Pens }\end{array}$ & $\begin{array}{l}\text { Length }^{2} \\
\text { (m) }\end{array}$ & $\begin{array}{l}\text { Apex }^{3} \\
\text { (m) }\end{array}$ & $\begin{array}{c}\text { Wall Height }{ }^{4} \\
\text { (cm) }\end{array}$ & $\begin{array}{c}\text { References or } \\
\text { Recorder }^{6}\end{array}$ \\
\hline FL:C11 & $\begin{array}{l}\text { Northern coast } \\
\text { of Barber } \\
\text { Island }\end{array}$ & Barber Bay & Stone & Trap & - & - & $(20)$ & - & - & Hatte 1997 \\
\hline FL:C26 & Barber Island & Barber Bay & Stone & Trap & & & & & & Hatte 1997 \\
\hline FL:C27 & Palm Island & Casement Bay & Stone & Trap & & & & & & Hatte 1997 \\
\hline $\begin{array}{l}\text { FL:C31- } \\
\text { C36 }\end{array}$ & $\begin{array}{l}\text { Hinchinbrook } \\
\text { Island }\end{array}$ & $\begin{array}{l}\text { Missionary } \\
\text { Bay }\end{array}$ & Stone & Traps & & & & & & Campbell 1982 \\
\hline FM:A31 & High Island & & Stone & Trap & - & - & - & - & 1 & - \\
\hline FM:B42*! & Clump Point & Boat Bay & Stone & Trap & Linear & 2 traps & $26 ; 30$ & & & Bird 1994a \\
\hline FM:B44! & Clump Point & Boat Bay & Stone & Trap & Arc & 2 & 39 & 52 & - & Bird 1994b \\
\hline FM:B64 & Browns Beach & & Stone & Weir & Arc & - & - & - & - & $\begin{array}{l}\text { Duke and } \\
\text { Collins 1994a }\end{array}$ \\
\hline FM:C08 & $\begin{array}{l}\text { Mulgrave } \\
\text { River }\end{array}$ & Yidindji & & & & & & & & \\
\hline FN:B97 & Sunny Bay & TC-5 & Stone & Trap & Arc & - & - & - & - & Cribb 1997 \\
\hline GJ:A37* & Adelaide Point & & Stone & Trap & Arc & 1 & 6.5 & & & Hill 1981 \\
\hline GK:A10* & $\begin{array}{l}\text { Abbott Point, } \\
\text { Caley Valley } \\
\text { Station }\end{array}$ & JU2 & Stone & Trap & Arc & - & 40 & - & $40-50$ & Bird 2009 \\
\hline GK:A52^ & R.M. Creek & Lisgar & Stone & Trap & Arc & 1 & 15 & - & 50 & Bird 1987 \\
\hline $\mathrm{HB}: \mathrm{A} 02^{\wedge}$ & $\begin{array}{l}\text { Balonne River, } \\
\text { Dunbar } \\
\text { Station, Surat }\end{array}$ & & Stone & Trap & & $>1$ & - & - & - & $\begin{array}{l}\text { Richardson } \\
1983\end{array}$ \\
\hline HC:A42^ & $\begin{array}{l}\text { Snake Creek, } \\
\text { Banoona } \\
\text { Station, Roma }\end{array}$ & Banoona & Organic & Weir? & - & - & - & - & - & - \\
\hline HH:A04 & $\begin{array}{l}\text { Reliance } \\
\text { Creek, Neils } \\
\text { Beach, Mackay }\end{array}$ & & Stone & Trap & - & 1 trap & - & - & $30-36 ?$ & McGarry 1987 \\
\hline HH:A15* & $\begin{array}{l}\text { McCready } \\
\text { Creek }\end{array}$ & & Stone & Weir & Linear & $1 ?$ & 5 & - & - & McGarry 1987 \\
\hline HH:A16! & $\begin{array}{l}\text { Sunset Bay, } \\
\text { Eimeo }\end{array}$ & Sunset Bay & Stone & Trap? & - & - & 34 & - & - & McGarry 1987 \\
\hline HH:A17* & $\begin{array}{l}\text { Gallagher } \\
\text { Creek, Eimeo }\end{array}$ & $\begin{array}{l}\text { Gallagher } \\
\text { Creek }\end{array}$ & Stone & Weir? & - & - & $68.3 ?$ & - & 50 & McGarry 1987 \\
\hline HH:A19^! & $\begin{array}{l}\text { Eimeo Beach, } \\
\text { Eimeo }\end{array}$ & Eimeo Beach & Stone & Weir? & - & - & - & - & - & McGarry 1987 \\
\hline HH:A20!* & Pioneer River & $\begin{array}{l}\text { Dumbleton } \\
\text { Rocks }\end{array}$ & Stone & Weir? & - & - & - & - & - & $\begin{array}{l}\text { Border } 1994 \\
\text { McGarry } 1987\end{array}$ \\
\hline
\end{tabular}




\begin{tabular}{|c|c|c|c|c|c|c|c|c|c|c|}
\hline Site ID & Location & Site Name & Material & Type & Shape $^{1}$ & $\begin{array}{c}\text { No. of } \\
\text { Pens }\end{array}$ & $\begin{array}{c}\text { Length }^{2} \\
\text { (m) }\end{array}$ & $\begin{array}{c}\text { Apex }^{3} \\
\text { (m) }\end{array}$ & $\begin{array}{c}\text { Wall Height }{ }^{4} \\
\text { (cm) }\end{array}$ & $\begin{array}{c}\text { References or } \\
\text { Recorder }^{6}\end{array}$ \\
\hline $\begin{array}{l}\mathrm{HH}: \mathrm{A} 40 * / \\
1-9\end{array}$ & $\begin{array}{l}\text { Freshwater } \\
\text { Point }\end{array}$ & $\begin{array}{l}\text { Freshwater } \\
\text { Point } 1\end{array}$ & Stone & Trap & Arc & $\begin{array}{l}1 \text { trap, } 2 \\
\text { pens }\end{array}$ & - & $\begin{array}{l}90 \text { larger } \\
\text { pen }\end{array}$ & 20 & Bird 1996b \\
\hline $\begin{array}{l}\text { HH:A42/1- } \\
34\end{array}$ & $\begin{array}{l}\text { Freshwater } \\
\text { Point }\end{array}$ & $\begin{array}{l}\text { Freshwater } \\
\text { Point } 3\end{array}$ & Stone & Trap & Arc & $1 ; 1$ & $80 ; ?$ & - & 20 & $\begin{array}{l}\text { Bird 1996b; } \\
\text { Barker \& } \\
\text { Bernard } 2007\end{array}$ \\
\hline HH:A74! & $\begin{array}{l}\text { West Hill } \\
\text { Island }\end{array}$ & & Stone & Trap & - & - & 80 & - & 25 & Border 1992 \\
\hline HH:A75* & Hay Point & & Stone & Trap & Arc & 1 & 65 & 2.2 & 40 & Bird 1996b \\
\hline HJ:A03 & Woodwark Bay & & Stone & Trap & - & - & - & 50 & - & Barker 1992a \\
\hline HJ:A06 & Midge Point & & Stone(Coral) & Trap & Arc & - & - & - & 40 & $\begin{array}{l}\text { Barker \& } \\
\text { Bernard } 2007\end{array}$ \\
\hline HJ:A14^ & Seaforth Beach & & Stone & Trap? & Arc & - & - & - & 10 & $\begin{array}{l}\text { McGarry 1987; } \\
\text { Barker \& } \\
\text { Bernard } 2007\end{array}$ \\
\hline HJ:A15^^ & Dewars Point & & Stone? & Trap? & - & - & - & - & $61-91$ & - \\
\hline $\begin{array}{l}\text { HJ:A18* } \\
\text { (Duplicates } \\
\text { HJ:A07) }\end{array}$ & $\begin{array}{l}\text { Sandy Bay, } \\
\text { Cape } \\
\text { Hillsborough. }\end{array}$ & & Stone & Weir & Linear & 1 trap & 65 & 80 & $20-30$ & $\begin{array}{l}\text { Border and } \\
\text { Hall 1994; } \\
\text { Barker \& } \\
\text { Bernard } 2007\end{array}$ \\
\hline HJ:A29! & Midge Point & & Stone & Trap & Square & 1 & 60 & 16 & 70 & $\begin{array}{l}\text { Barker 1988, } \\
\text { 1992a }\end{array}$ \\
\hline HJ:A34 & Green Island & & Stone & Trap & Arc & 1 & 200 & - & $30-45$ & McGarry 1987 \\
\hline HJ:A35!* & Rabbit Island & & Wood? & Trap & $\mathrm{V}$ & - & - & - & - & McGarry 1987 \\
\hline HJ:A36! & $\begin{array}{l}\text { Covering } \\
\text { Creek }\end{array}$ & & Stone & Weir & - & - & 13 & - & 60 & $\begin{array}{l}\text { Barker 1988, } \\
\text { 1992a }\end{array}$ \\
\hline HJ:A76 & Woodwark Bay & & Stone & Weir & - & - & 15 & - & - & Barker 1992a \\
\hline HJ:A96 & $\begin{array}{l}\text { South Repulse } \\
\text { Island }\end{array}$ & & Stone & Trap & Arc & & & & & Barker 1992b \\
\hline HJ:B03 & $\begin{array}{l}\text { Mentmore } \\
\text { Beach }\end{array}$ & & Stone? & Trap? & & & & & $60-90$ & \\
\hline JC:A21 & $\begin{array}{l}\text { Branch Creek, } \\
\text { Cannon Dee } \\
\text { Station }\end{array}$ & & Stone? & Weir? & & & & & & \\
\hline JC:A93 & Kogan & & Stone? & Weir? & - & - & - & - & - & - \\
\hline KA:A67 & $\begin{array}{l}\text { Near } \\
\text { Beaudesert }\end{array}$ & & $\begin{array}{l}\text { Waterholes } \\
\text { for fishing. } \\
\text { Limited } \\
\text { information }\end{array}$ & & & & & & & John Long \\
\hline
\end{tabular}




\begin{tabular}{|c|c|c|c|c|c|c|c|c|c|c|}
\hline Site ID & Location & Site Name & Material & Type & Shape $^{1}$ & $\begin{array}{l}\text { No. of } \\
\text { Pens }\end{array}$ & $\begin{array}{c}\text { Length }^{2} \\
(\mathrm{~m})\end{array}$ & $\begin{array}{c}\text { Apex }^{3} \\
\text { (m) }\end{array}$ & $\begin{array}{c}\text { Wall Height }^{4} \\
(\mathrm{~cm})\end{array}$ & $\begin{array}{c}\begin{array}{c}\text { References or } \\
\text { Recorder }^{6}\end{array} \\
\end{array}$ \\
\hline KA:A72 & $\begin{array}{l}\text { Near } \\
\text { Beaudesert }\end{array}$ & & $\begin{array}{l}\text { Waterholes } \\
\text { for fishing. } \\
\text { Limited } \\
\text { information }\end{array}$ & & & & & & & John Long \\
\hline KB:F91 & $\begin{array}{l}\text { North Pine } \\
\text { River }\end{array}$ & $\begin{array}{l}\text { Rain Increase } \\
\text { Site }\end{array}$ & & Weir & & & & & & \\
\hline KC:D93 & Bli Bli & $\begin{array}{l}\text { Area of fish } \\
\text { traps and other } \\
\text { sites. Limited } \\
\text { information }\end{array}$ & & & & & & & & Su Davies \\
\hline KC:E41! & Lake Weyba & & Stone & Trap ? & - & - & - & - & - & - \\
\hline KD:A13 & Booral & Area 4 & Stone & Trap & Arc/M & $\begin{array}{l}1 \text { trap, } 3 \\
\text { pens }\end{array}$ & a few; 129 & - & $20-50$ & McNiven 1994 \\
\hline KD:A14 & Booral & Area 3 & Stone & Trap & Arc & 4 traps & $30 ; 40$ & - & 1 & McNiven 1994 \\
\hline KD:A15 & Booral & Area 2 & Stone & Trap & Arc & 5 traps & 150 & - & $10-25$ & McNiven 1994 \\
\hline KD:A17 & Woody Island & & Stone & Trap & Arc?/V & -1 trap & - & - & - & $\begin{array}{l}\text { Lauer 1979; } \\
\text { Frankland } \\
\text { 1990; McNiven } \\
1992\end{array}$ \\
\hline KD:B23 & Booral & Area 1 & Stone & Trap & Linear & 1 trap & 35 & & & McNiven 1994 \\
\hline KD:B24 & Booral & Area 5 & Stone & Trap & One arc & 2 traps & $\begin{array}{l}\text { Arc 25, linear } \\
70\end{array}$ & & & McNiven 1994 \\
\hline KD:A45! & Point Vernon & & Stone & Trap & & & $23 \mathrm{~m}$ & $26 \mathrm{~m}$ & 50 & \\
\hline KE:A22*! & Burnett Heads & & Stone & Trap & Arc & 2 pens+ & 30 & - & 100 & $\begin{array}{l}\text { Godwin 1992; } \\
\text { Foley } 1992\end{array}$ \\
\hline KF:A12 & $\begin{array}{l}\text { Rodds } \\
\text { Peninsula }\end{array}$ & Richards Point & Stone & Trap? & Arc & - & - & - & - & Burke 1993 \\
\hline LA:A38!^ & $\begin{array}{l}\text { Tallebudgera } \\
\text { Creek }\end{array}$ & & Stone & Trap & Oval & 1 trap/pen & 100 & - & - & $\begin{array}{l}\text { Alfredson } \\
\text { 1995; Black } \\
1995\end{array}$ \\
\hline LA:C80 & $\begin{array}{l}\text { Burleigh } \\
\text { Fishtrap }\end{array}$ & & Stone & Trap & & & & & & \\
\hline LB:A37!* & Toorbul Point & & Stone & Trap & Arc & 1 & 73 & - & $30-100$ & $\begin{array}{l}\text { Stockton 1975; } \\
\text { Hogan et al. } \\
\text { 1992; Walters } \\
\text { 1985; } \\
\text { Anonymous } \\
1990\end{array}$ \\
\hline
\end{tabular}


1. Fish traps occur as an arc (U), 'V'-shaped (V), maze-like (M) or circular (O). Weirs are simple walls.

2. Longest wall in arc or line. If part of complex then, the shortest and longest walls.

3. The longest line from the trap's outer termination to intersect a line connecting the trap's landward edges. If part of complex then, the shortest and longest lines.

4. Average height from land surface to top of wall.

5. Widest point

6. Recorder cited where no reference available

* degrading.

$\wedge$ destroyed/buried.

! origin uncertain. 